\title{
The Pine-Popple River Basin- Hydrology of a Wild River Area, Northeastern Wisconsin
}

GEOLOGICAL SURVEY WATER-SUPPLY PAPER 2006

Prepared in cooperation with the

University of Wisconsin-Extension, Geological and Natural History Survey

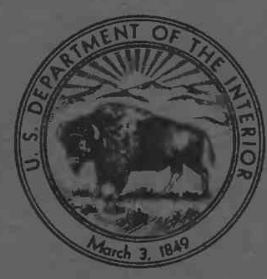




\section{The Pine-Popple River Basin- Hydrology of a Wild River Area, Northeastern Wisconsin}

$B y$ EDWARD OAKES, STEPHEN J. FIELD, and LAWRENCE P. SEEGER

GEOLOGICAL SURVEY WATER-SUPPLY PAPER 2006

Prepared in cooperation with the

University of Wisconsin-Extension,

Geological and Natural History Survey

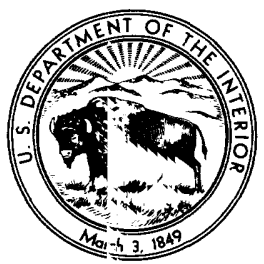




\section{UNITED STATES DEPARTMENT OF THE INTERIOR}

ROGERS C. B. MORTON, Secretary

\section{GEOLOGICAL SURVEY}

V. E. McKelvey, Director

Library of Congress catalog-card No. 73-600065 


\section{CONTENTS}

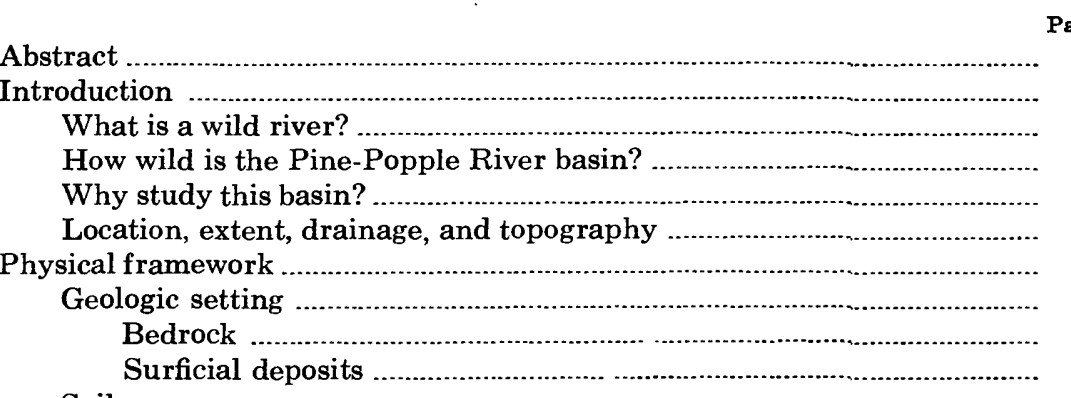

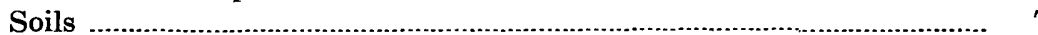

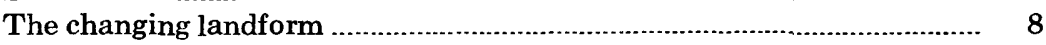

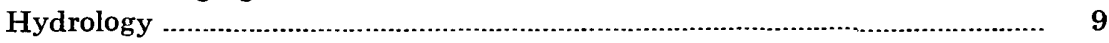

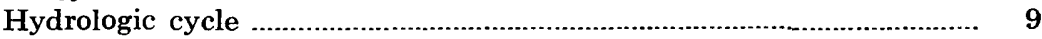

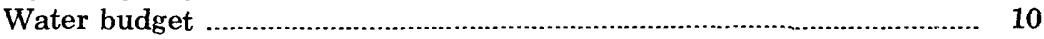

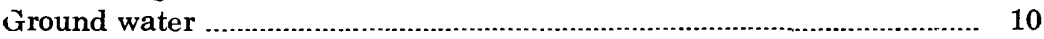

Ground-water occurrence ............................................................... 11

Ground-water movement ............................................................... 11

Ground-water availability ......................................................... 12

Ground-water quality ............................................................... 12

Surface water ................................................................................. 15

Flow duration

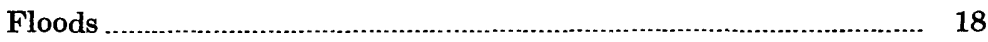

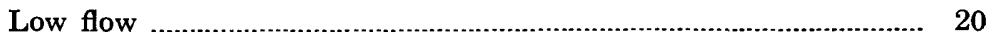

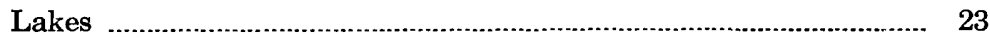

Surface-water quality ...................................................................... 23

Ground water-surface water relationships ............................................ 28

Streams and their relation to ground water .................................... 28

Lakes and their relation to ground water and streams .................... 37

Water use ..................................................................................... $\quad 37$

Withdrawal use .......................................................................... 38

Nonwithdrawal use .......................................................................... $\quad 40$

Nonrecreational use ............................................................ 40

Recreational use ....................................................................... 41

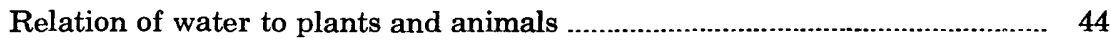

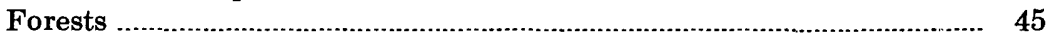

Aquatic vegetation .............................................................................. 46

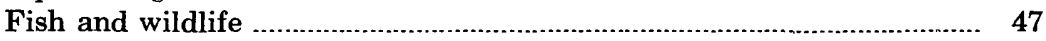

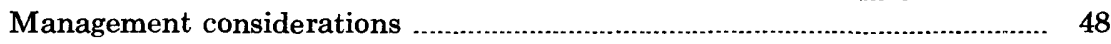

Summary and conclusions ..................................................................... 50

Selected references ......................................................................... 52

Wisconsin Wild Rivers Bill ...................................................................... 54

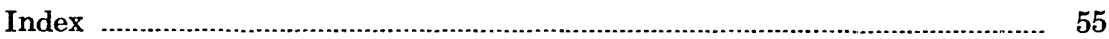




\section{ILLUSTRATIONS}

Plate

Figure

\section{9-12. Graphs showing:}

1. Geologic maps of the Pine-Popple River basin, northeastern Wisconsin

2. Geohydrologic maps of the Pine-Popple River

basin, northeastern Wisconsin
1. Index map showing location of the Pine-Popple In pocket River basin In pocket

2. Profiles of the Pine and Popple Rivers and major tributaries

3. Map showing location of data collection sites

4. Hydrograph showing monthly mean discharge of Pine River at site A

5. Duration curves of daily flow of the Pine River at sites $\mathrm{A}$ and $\mathrm{A}^{\prime}$

6. Duration curves of daily flow of the Pine River at site A ..

7. Graph showing maximum and minimum monthly runoff of Pine River at site A

8. Diagram showing streamflow accretion of Pine and Popple Rivers, August 16-19, 1967

9. Maximum and minimum monthly stream temperatures of the Popple River at site B

10. Comparison of stream temperatures for Popple River at site B and for Woods Creek

11. Diurnal fluctuations of dissolved oxygen, percent of DO saturation, and tempersture, September 7-8, 1967

12. Relationship between precipitation, ground-water stage, and base runoff

13. Duration curves of daily flow of the Pine and Pornle Rivers at sites A, B, and C for climatic year 1957

14. Duration curves of daily flow of the Pine and Popple Rivers at sites D, E, F, and G for climatic year 1967 ....

15. Map showing ground-water movement in and ar`und Franklin, Butternut, and Morgan Lakes

16. Graph showing comparison of water-level flucturtions
in a well, a drainage lake, and a seepage lake ...............

16. Graph showing comparison of water-level fluctu
in a well, a drainage lake, and a seepage lake

\section{TABLES}

TABLE

1. Selected chemical analyses of well water from in and near the Pine-Popple River basin

2. Selected lakes of the Pine-Popple River basin

3. Chemical analyses of stream low flow in the Pine-Popple River basin

4. Chemical analyses of streams under conditions of flow greater than low flow in the Pine-Popple River basin.....

5. Supplemental physical and biological analyses at site B ..

6. Streamflow measurements for South Branch Popple River above Simpson Creek and for Simpson C -eek.......

7. Canoeability rating of selected rapids, falls, and braided sections of streams 


\title{
THE PINE-POPPLE RIVER BASIN- HYDROLOGY OF A WILD RIVER AREA, NORTHEASTERN WISCONSIN
}

\author{
By Edward Oakes, Stephen J. Field, and Lawrence P. Seeger
}

\begin{abstract}
The Pine and Popple Rivers, virtually unaltered by man, flow through a semiprimitive area of forests, lakes, and glacial hills. White-water streams, natural lakes, fish and animal life, and abundant vegetation contribute to the unique recreational and aesthetic characteristics of the area. Resource $r^{\text {lanning }}$ or development should recognize the interrelationships within the hydrologic system and the possible effects of water and land-use changes upon the wild nature of the area.

The basin covers about 563 square miles in northeastern Wisconsin. Swamps and wetlands cover nearly 110 square miles, and the 70 lakes cover shout 11 square miles. The undulating topography is formed by glacial deposits overlying an irregular, resistant surface of bedrock.

An annual average of 30 inches of precipitation, highest from late suring to early autumn, falls on the basin. Of this amount, evapotranspiration, highest in mid summer and late summer, averages 19 inches; the remaining 11 inches is runoff, which is highest in spring and early summer.

Ground water from the glacial drift is the source of water for th? minor withdrawal use in the basin. Ground-water movement is to streams and lakes and regionally follows the slope of topography and the bedrock surface, which is generally west to east. Ground water is of good quality, although locally high in iron.

The major uses of water are for recreation and power generation. I omestic use is slight. No water is withdrawn from lakes or streams, and no se-vage or industrial wastes are added to lakes or streams. Most of the flow of the Pine River is used for power generation. The main stems of the Pine and Popple Rivers contain 114 canoeable miles, of which 95 percent is without such major obstructions as falls or large rapids. In general streams support cold-wa ter fish, and lakes support warm-water fish. Trout is the principal stream and game fish in the basin.

The basin has no significant water problems. Future development between the Pine River powerplant and the mouth of the Pine River should have little effect on the western two-thirds of the basin, already largely protected b:r public ownership or development planning agreements.
\end{abstract}




\section{INTRODUCTION}

\section{WHAT IS A WILD RIVER?}

A wild river area, as defined in a policy statement of the Wisconsin Department of Natural Resources, "is a stream or section of a stream, tributary, or river-and the related adjacent lands-located in a sparsely populated, natural and rugged environment where the river is free-flowing and unpolluted, or where the river should be restored to such condition, in order to promote sound water conserration, and promote the public use and enjoyment of the scenic, fish, wildlife, and outdoor recreation values." (Wisconsin Department of Natural Resources, written commun., 1967.) Generally most wild rivers are cold-water streams exhibiting natural waterways in an area of characteristic topography, varied vegetation, game fish and mammals, lakes and wetlands, and scenic landscapes. From these conditions arising from land and water resources, man derives certain recreational and environmental values.

As a result of public interest in preserving the values $c^{f}$ wild river areas, the Wisconsin Legislature, on November 18, 1965, enacted Statute 30.26 (see section on "Wisconsin Wild River Bill") expressly designating the Pine and Popple Rivers as wild rivers so that they may be preserved and protected, and their characteristics b? enhanced.

\section{HOW WILD IS THE PINE-POPPLE RIVER BASIN?}

The Pine-Popple River basin is as wild and has as little development as any area in the State of Wisconsin even though the area is not as primitive as a true wilderness area. This wild appearance has been retained because the area is remote from population centers, is isolated by geography, lacks economic mineral resources, and is partly protected by forestry laws.

\section{WHY STUDY THIS BASIN?}

To preserve the wild character of the Pine River and its principal tributary, the Popple River, a thorough understanding of the water resources and their relationships to land, life forms, water use, and resource development must be developed for the entire basin. The purpose of this study is to provide both basic and refined information on water resources and water use to be utilized in making wise decisions for the management of the Pine-Popple area.

The objectives of the Pine-Popple River basin study are to:

1. Identify and describe the water resources of the basin and determine the operation of the hydrologic system.

2. Relate this system to recreational development, conservation, and man's current use of the land and water resources. 
3. Interpret the implications of land and water management on the water system.

This report describes the water resources and the hydrologic sys. tem of the Pine-Popple River basin during 1966 and 1967. It relates this system to the physiography and life forms of the basin and discusses the possible consequences of various kinds of land and waterresource development.

The Water Resources Division, U.S. Geological Survey, and the University of Wisconsin-Extension, Geological and Natural J'istory Survey cooperated in this study. In addition, the study was conducted in close collaboration with the Wisconsin Department of I'atural Resources.

A concurrent wild rivers study was sponsored by the Wisconsin Academy of Sciences, Arts and Letters to collect biologic and other information, some of which is related to this report.

Data were furnished by the Geological and Natural History Survey: the Wisconsin Department of Natural Resources, the Wisconsin State Laboratory of Hygiene, the U.S. Department of Agriculture Forest Service and Soil Conservation Service, and the Wisconsin-Michigan Power Company. These contributions were invaluable.

Special thanks are accorded to the following: Mr. Jack Mason for game-fish studies and supplemental chemical analyses; Professor Galen Smith and Mr. Robert Rose for studies of aquatic flora; Mr. Harry Kleiman for well-drilling data; Dr. Carl Dutton for information on the bedrock geology; Professor Francis Hole for information on the soils of the area and review of the soil text; Mr. Joe Mills for canoeing information; and Dr. Roger Bay for suggestions and information on peat-bog hydrology. Not to be overlooked are the many observers, canoeists, and homeowners who furnished information.

\section{LOCATION, EXTENT, DRAINAGE, AND TOPOGRAPHY}

The Pine and Popple Rivers drain an area of approximataly 563 square miles in northeastern Wisconsin (fig. 1). The Pine-Popple River basin is about 43 miles long and 18 miles wide, and it drains eastward into the Menominee River, which flows into Lake Mirhigan. Drainage density is low, and the western two-thirds of the area is swampy because it is poorly drained.

The Pine River, which has a length of about 78 miles, has a relatively flat gradient in its headwaters and a steeper gradient downstream. The Pine River rises in marsh and swamp at the surfac?-water divide and flows east for about 19 miles with a gradient of about 2 feet per mile. This swampy area drains outwash. The stream gradient increases to 8 feet per mile for 25 miles; then, for the next 22 miles, where the river flows over resistant bedrock and end moraine, the gradient increases to 14 feet per mile. For the last 12 miles; where 


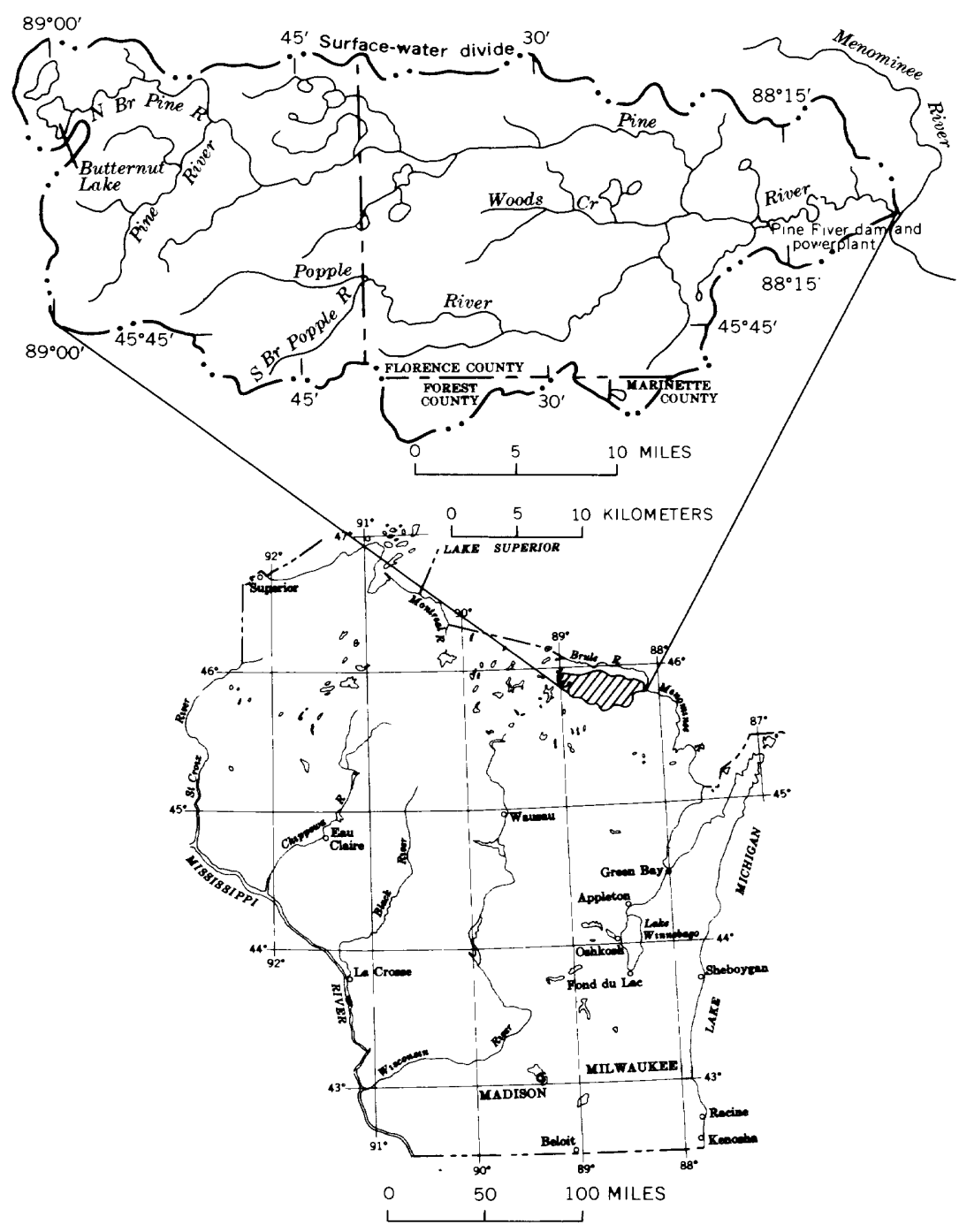

Figure 1.-Location of the Pine-Popple River basin in Wisconsin.

the river flows over a preglacial valley and before the river enters the Menominee River, the gradient is one-half foot per mile (fig. 2).

The Pine River enters an impoundment on the Menominee River. On the Pine River a backwater effect may extend 2 miles upstream from the mouth; the normal effect probably extends only about onefourth mile.

The Popple River has a gradient similar to that of the ??ine River. It rises in swamp and marsh at its surface-water divide and flows at 


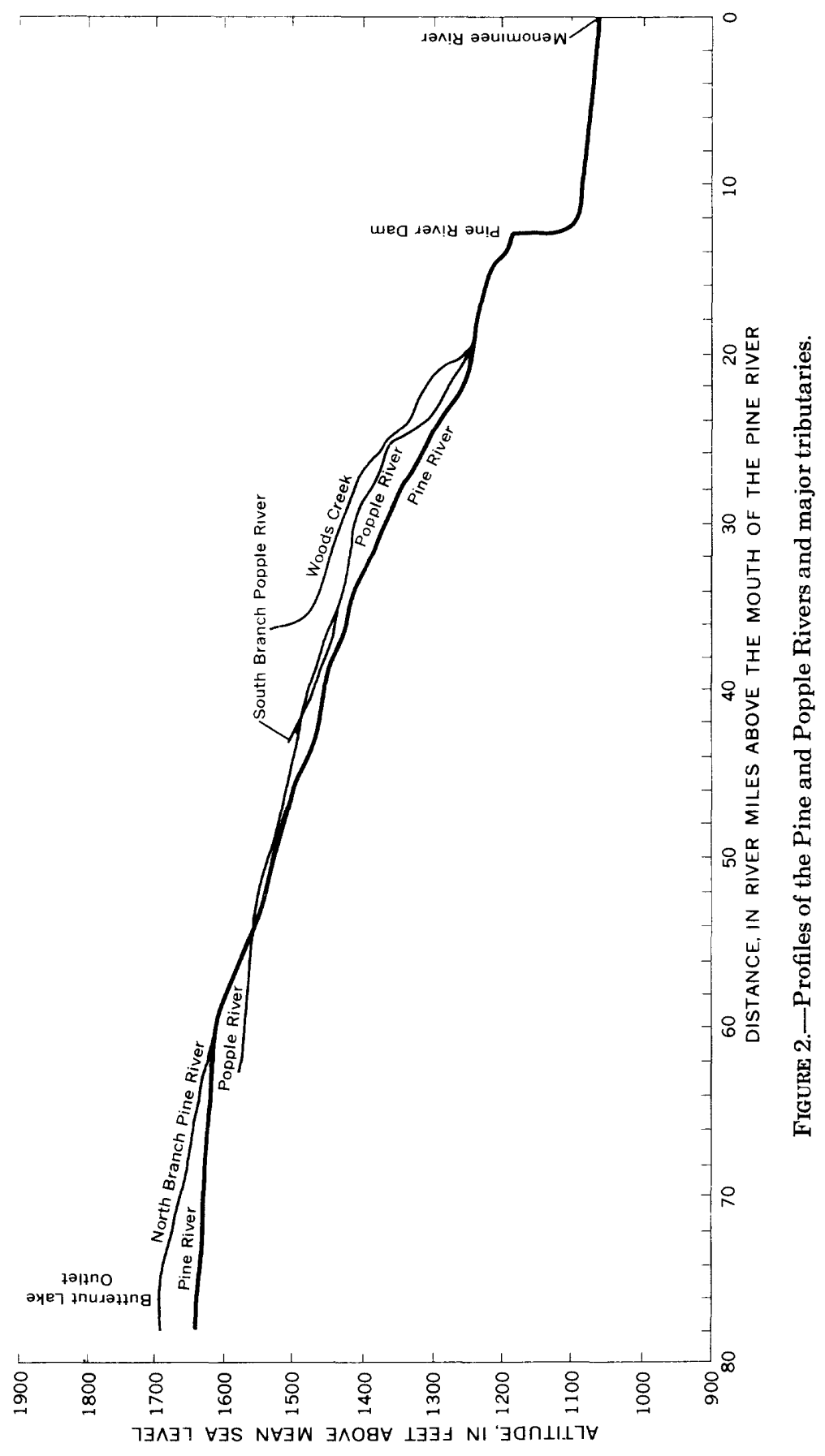


a gradient of 2 feet per mile for 10 miles. The stream gradient increases to 6 feet per mile for 22 miles, then increases to 16 feet per mile for 13 miles, before the stream enters the Pine River. The total length of the Popple River is about 45 river miles.

The Pine-Popple River basin has a rolling topography and slopes towards the east. In the northwest, knob and swale topog:aphy predominates, and in the southwest extensive marshlands are crossed by northeast-trending ridges. In the east the prominent hil $>$ and the deeply entrenched valley of the Pine River result in local relief of about 350 feet.

The highest point in the basin is about 1,830 feet above mean sea level, near Butternut Lake. The North Branch Pine River originates at the outlet of Butternut Lake at an altitude of 1,695 feet. The Pine River enters the Menominee River at an altitude of 1,068 feet.

\section{PHYSICAL FRAMEWORK}

For a better understanding of the rivers, streams, lakes, wetlands, and underground water of an area, it is necessary to identif: and describe the physical framework of the basin, which includes the geology, soils, topography, and vegetation.

\section{GEOLOGIC SETTING}

\section{BEDROCK}

The bedrock in the Pine-Popple River basin is a continuation of the Canadian Shield, the ancient basement complex of the North American Continent. These rocks are Precambrian in age and include igneous and metamorphic types. With the exception of the eastern one-fourth of the area, little is known about the distribution of rock types because of a covering mantle of drift. For the wertern part known and inferred bedrock geology (Dutton and Bradley, 1970) is shown on plate 1. A geologic history of the bedrock in the eastern part of the basin was written by Bayley, Dutton, and Lamey (1966); the geologic map of the basin, shown on plate 1, incorporates additional data from Dutton and Linebaugh (1967).

The bedrock surface slopes from west to east about 10 fect, per mile, which conforms to the general eastward slope of the Wisconsin Arch. This surface is irregular, and large hills and preglacial valleys are evident in the eastern part of the basin. Data are inadequate to deteinine local variations. The generalized configuration of the bedrock surface (pl. 1) was determined from well records and outcrops. The bedrock units in the western two-thirds of the basir are more resistant to erosion than the bedrock units at the east end. The Pine and Popple Rivers form numerous rapids and falls where they flow over granite, gneiss, and metavolcanic rocks. Near the mo'th of the 
Pine River, where the water flows over metasedimentary b?drock, the river is at its lowest gradient and does not form rapids or falls.

Preglacial drainage was generally from west to east, conforming to the bedrock surface. The lower reach of the Pine River was inf uenced by a preglacial channel. At the mouth of the Pine River, where the bedrock is the less resistant Michigamme Slate, the lowered kadrock surface may be part of an ancestral valley of the Menominee River, as shown by Hough (1958, fig. 29, p. 87).

The large hills in the area south of Florence have a core of very resistant rocks. These rocks form prominent outcrops and con tribute significantly to the local relief.

\section{SURFICIAL DEPOSITS}

Outwash and ice-contact deposits of sand and gravel occur th roughout the basin. The greatest thicknesses (as much as 200 feet) and areal extents of outwash are in the south-central (Popple River area), the extreme northwestern (Butternut Lake area), and the eastern (mouth of Pine River) parts of the basin (pl. 1). The outwash is not uniform in grain size and contains layers of less permeable material. Ice-contact deposits occur in close association with end moraine.

Swamp deposits are scattered throughout the basin and consist largely of peat and muck. These deposits are generally less than 10 feet thick and commonly overlie outwash deposits. The largest wetlands are drainage meadows in the western and southern parts of the basin. Numerous small wetlands occupy kettles and the marrins of lakes and streams.

Till occurs as ground moraine and end moraine in the basin. Ground moraine, consisting predominantly of sandy clay till, is abundant in the western part of the area. Sand and gravel are generally absent from the northeast-trending moraines in the west. Drumlins are scattered on the till, many underlying local outwash deposits.

In the eastern part of the basin a broad and discontinuous belt of sandy clay till overlies bedrock. Ice-contact deposits consisting of coarse sand and gravel are commonly associated with the till. The till is as much as $\mathbf{1 5 0}$ feet thick.

\section{SoILs}

The type of soil that develops in an area depends upon the local rock types, topography, and climate. Soils are discussed in this report because they control the infiltration of precipitation and the distribution and kinds of vegetation. These factors, in turn, influence runoff and erosion. The major soil types in the basin and their relation to wildlife, recreation, forestry, geology, hydrology, and agricult tre are indicated on plate 2. 
Goodman, Stambaugh, and associated soils (F5) are th? predominant soil association in the basin and occur in the south-central and east-central parts of the basin (pl. 2). Goodman and Stambaugh soils develop on sandy ground moraine, end moraine, and outwash.

The Pence-Iron River soil association (G2 and G11) characteristically develop on clay till in ground and end moraine. Peat and muck soils ( $\mathrm{J} 2, \mathrm{~J} 12$, and $\mathrm{J} 13$ ) are found in wetlands.

Soils developed on end moraine and associated ice-contact topography are good to excellent for hiking and camping. Because of the steep topography, they are not usually well suited to agriculture. Soils developed on outwash are ideal for conifer growth. Where outwash soils are not clayey, a good potential for irrigation exists. These areas are also very good for hiking and camping. Wet, marshy soils must be drained to be suitable for agriculture. These wetland areas provide good habitats for wildlife.

Generally soils developed on till or in wetlands have the lowest infiltration rates, and soils developed on sand and gravel have the highest infiltration rates. In wetland areas the infiltration rates of moss peats are high, and the infiltration rates of sedge peats are low.

\section{THE CHANGING LANDFORM}

In spite of the low drainage density and lack of dissectic n, the area is topographically mature. The term "mature" means that "nearly all the gradation which can result from the operation of existing agencies has been accomplished" (Horton, 1945, p. 367). Further stream erosion and dissection of the topography is restricted because of high soilinfiltration capacities, high surface resistance to erosion because of vegetative cover, and stream-gradient control by resistant bedrock. Under existing climatic and land-use influences, these factors will greatly retard additional erosion within the basin.

Many present-day changes in the landform cannot be easily discerned because the rate of change is very slow. During th $1964-67$ water years, the average sediment yield of the Popple River near Fence, Wis., was 6.1 tons per square mile (Hindall and Flint, 1970). This low sediment yield reflects a low rate of erosion. A comparison of drainage features shown on 1938 and 1967 aerial photc ?raphs did not reveal changes, particularly in stream meander pattorns. Manmade changes such as farming, logging, and road construction have locally altered the rate of slope and streambank erosion, $k$ rt existing data do not allow these to be discussed quantitatively.

The period of greatest change was from 1890 to 1933, when logging was very active. Until about 1870 the area was a forested wilderness of lakes, swamps, and streams. Pine logging began about 1870 and reached a maximum about 1890 . By about 1900 the supply 
of pine had dwindled, and hardwood logging became important and was active until 1920. During the period 1870-1920 large sections of the forest were cut down or were destroyed by disastrous fires. To preserve some of this wooded area, the Nicolet National Forest was established in 1933; since then the area has undergone general reforestation.

Reforestation, particularly the plentiful second-growth aspen stands, has resulted in an increased beaver population (Wisconsin Conservation Department, 1961, p. 5). Beaver dams, because they impede streamflow by impounding, cause channel sedimentation, and the removal of cover for dam construction material may increase bank erosion.

One landform change in the Pine-Popple River basin is the gradual disappearance of lakes by infilling with silt and organic material. Lakes are replaced by swamps or dry land. A lake enriched in plant nutrients is termed eutrophic; the enrichinng process leading to lake aging is termed eutrophication. This process is natural and continuous. A lake enriched in nitrate and phosphate may become so filled with algae, leafy plants, and decay debris that it chokes to death.

Many lakes in the basin have probably disappeared owing to drainage and the resultant lowering of the water table. Fay Lake, in the central part of the basin, shows evidence of eutrophication. Morgan Lake, in the south-central part of the basin, is an example of a nonenriched (oligotrophic) lake. The remainder of the lakes are mesotrophic; this is to say, enrichment levels are low.

\section{HYDROLOGY}

\section{HYDROLOGIC CYCLE}

The water in streams, lakes, and wetlands, as well as water underground and in the atmosphere, is part of a mobile circulatory system known as the hydrologic cycle.

Almost all water entering the Pine-Popple River basin is precipitation (rain or snow). Some rainfall and snowmelt directly runs off to streams, lakes, or swamps; some evaporates; some is transpired; and some infiltrates underground and becomes ground water.

Ground water moves from recharge areas to discharge areas, where it discharges to lakes, streams, and swamps.

Water leaves the basin as evapotranspiration or as runoff. Evapotranspiration includes evaporation from water surfaces, vegatation, and bare ground, and transpiration by plants. Runoff includes the direct overland flow of rainfall and snowmelt and the ground-water contribution to streams.

Ground and surface water are considered separately for conveni- 
ence in this report. However, they are part of the same hydrologic system operating in the basin. Any planning for the management of water resources must recognize this basic relationship.

\section{WATER BUDGET}

The hydrologic budget of the Pine-Popple River basin iv a quantitative account of the amount of water in the hydrologic system. A budget was prepared for the basin above the Pine River powerplant. For a given time period all water entering an area must be stored, evaporated, transpired, exported, or must flow from the area on or beneath the surface. The simplest hydrologic budget is or $\%$ in which input equals output.

A long-term budget of this basin is an average annual budget based on the 1924-67 record of flow of the Pine River above the Wisconsin-Michigan Power Company's powerplant. The budget area is 528 square miles, which is about 94 percent of the total study area.

To determine this budget, precipitation and runoff were measured. Long-term changes in ground-water storage were assumed to equal zero; this assumption is based on the water-level rydrograph of well Fr-2, a well which is about 5 miles north of the basin (Devaul, 1967, p. 51). Soil-moisture and surface-storage changes are also assumed to equal zero. No significant amount of underflow enters or leaves the basin.

The long-term average annual value for evapotranspiration in the basin is about 19 inches. Evapotranspiration is the residual amount after runoff has been subtracted from precipitation. Because there is no significant consumption of water by people, municinalities, or industries, the amount of evapotranspiration is essentially that evaporated from free water surfaces, vegetation, bare ground, and that water transpired by plants.

Precipitation over the area averages about 30 inches annually, based on seven U.S. Weather Bureau stations having record periods ranging from 39 to 71 years. Stations with shorter record periods (8-23 years) were not used. Long-term average annual procipitation ranges from about 32 inches in the west to less than 29 inches in the east.

Runoff from the area above the Pine River powerplant for 1924-67 averaged about 11 inches annually. This figure is obtrined from daily discharges compiled by the Wisconsin-Michigan Power Company (U.S. Geological Survey, 1968, p. 28).

\section{GROUND WATER}

Ground water is a renewable resource that contributes to the availability of water in other phases of the hydrologic cycle. To understand the ground-water part of the hydrologic system operat- 
ing in the Pine-Popple River basin, the occurrence, movement, availability, and quality of ground water were determined.

GROUND-WATER OCCURRENCE

Ground water occurs in saturated deposits, generally less than 50 feet thick, throughout the Pine-Popple basin. These deposits include permeable sand and gravel and slightly permeable till. In the ground moraine area in the western part of the basin, the till is locally overlain by permeable outwash sand and gravel. The till within the end moraine in the east lies on the bedrock surface and includes permeable ice-contact deposits. Crystalline bedrock is in effect impermeable, and its surface forms a lower limit for the groundwater body. The water table generally is within 10 feet of the land surface in wetlands and other flat-lying areas. Depth to the water table below hills is highly variable and is as much as 150 feet.

\section{GROUND-WATER MOVEMENT}

Ground water moves from areas of recharge to areas of discharge. The rate at which ground water is replenished is governed by the amount and intensity of precipitation, the infiltration capacity of the soil, and the permeability of the underlying materials.

Ground water is discharged into local surface-water bodies, and ground-water movement is toward these points. The ground-water storage reservoir is thin, there are no continuous confining horizons, and the gradient is relatively steep; for these reasons the groundwater flow paths are short. In the Pine-Popple River basin, most ground water is discharged within 5 miles of the point of recharge. The rate of ground-water movement is determined by the permeability of the material through which the water passes and by the gradient of the water table. A steep gradient is associated vith low permeability or steep topography. Steep gradients on the watertable surface in the eastern part of the basin are related to a bedrock surface that slopes to the east. Near-surface bedrock in the eastern part of the basin is a local barrier to ground-water movement and diverts flow to longer paths of movement. The regional gradient on the water table is from west to east (pl. 2).

Ground water moves into lakes generally from the west, and discharge from the lakes is to the east either by streams or underground flow.

In the large wetland areas of the surface-water divides, the groundwater gradient is flat and water movement is slow.

Ground-water gradients are low, between 10 and 15 feet Fer mile, in the western two-thirds of the basin because the topography is flat and the sand and gravel deposits are permeable (pl. 2). Steep gradients occur locally in the western part of the basin becruse the ground moraine has low permeability. 


\section{GROUND-WATER AVAILABILITY}

Ground water for domestic use generally is readily available throughout the basin. Large supplies can be obtained locally (pl. 2). As much as $200 \mathrm{gpm}$ (gallons per minute) of water may be obtained in the western one-half of the basin. Locally, in areas where saturated sand and gravel deposits are over 50 feet thick, as much as $500 \mathrm{gpm}$ may be obtained. In the eastern and northeastern parts of the basin, the potential for ground water is only fair, and wells generally yield less than $100 \mathrm{gpm}$. As much as $500 \mathrm{gpm}$ of water may be obtained in the extreme eastern part of the basin where the saturated aquifer is more than 50 feet thick, and as much as 200 gpm may be obtained elsewhere.

Ground-water availability can only be estimated from geologic and hydrologic inference, rather than from proved resource occurrence, because no high-capacity wells exist in the basin.

Ground-water availability was inferred from the base runoff (ground-water contribution) of small tributary basins, surficial geology, soil infiltration rates, the saturated thickness of glacial drift, the spacing of contours on the water-table surface, local well records, and well yields from similar geologic areas.

\section{GROUND-WATER QUALITY}

Ground water in the Pine-Popple River basin is of good quality and is suitable for nearly all purposes. It is clear, cold, noderately hard, odorless, and noncorrosive. Ground-water samples from 16 wells in the area were chemically analyzed. The results are presented in table 1. The locations of the wells are shown in figure 3.

Ground-water temperature is important to water users. Ground water in the basin has the relatively constant and cool temperature of $7-8^{\circ} \mathrm{C}$ (Celsius) $\left(45-47^{\circ} \mathrm{F}\right)$. Ground water maintains nearly the same temperature as the average annual air temperature. The cool ground water constantly discharged into lakes and streams helps to maintain the surface-water temperature required by trout and other game fish.

Hardness concentrations in ground water in the basin are highly variable. Most of the water is moderately hard (61-120 $\mathrm{m}$ ? / [ [milligrams per liter] hardness) to hard (121-180 mg/l). Hardness ranged from 15 to $432 \mathrm{mg} / \mathrm{l}$ in the 16 analyses obtained (table 1 ). Water from shallow wells finished in permeable sand and gravel is soft and is low in total dissolved solids. Water from deep wells finished in sand and gravel beneath till is very hard and is high in conductivity and total dissolved solids.

Iron and manganese concentrations in ground water ir the basin are highly variable. High concentrations of iron and manganese dis- 


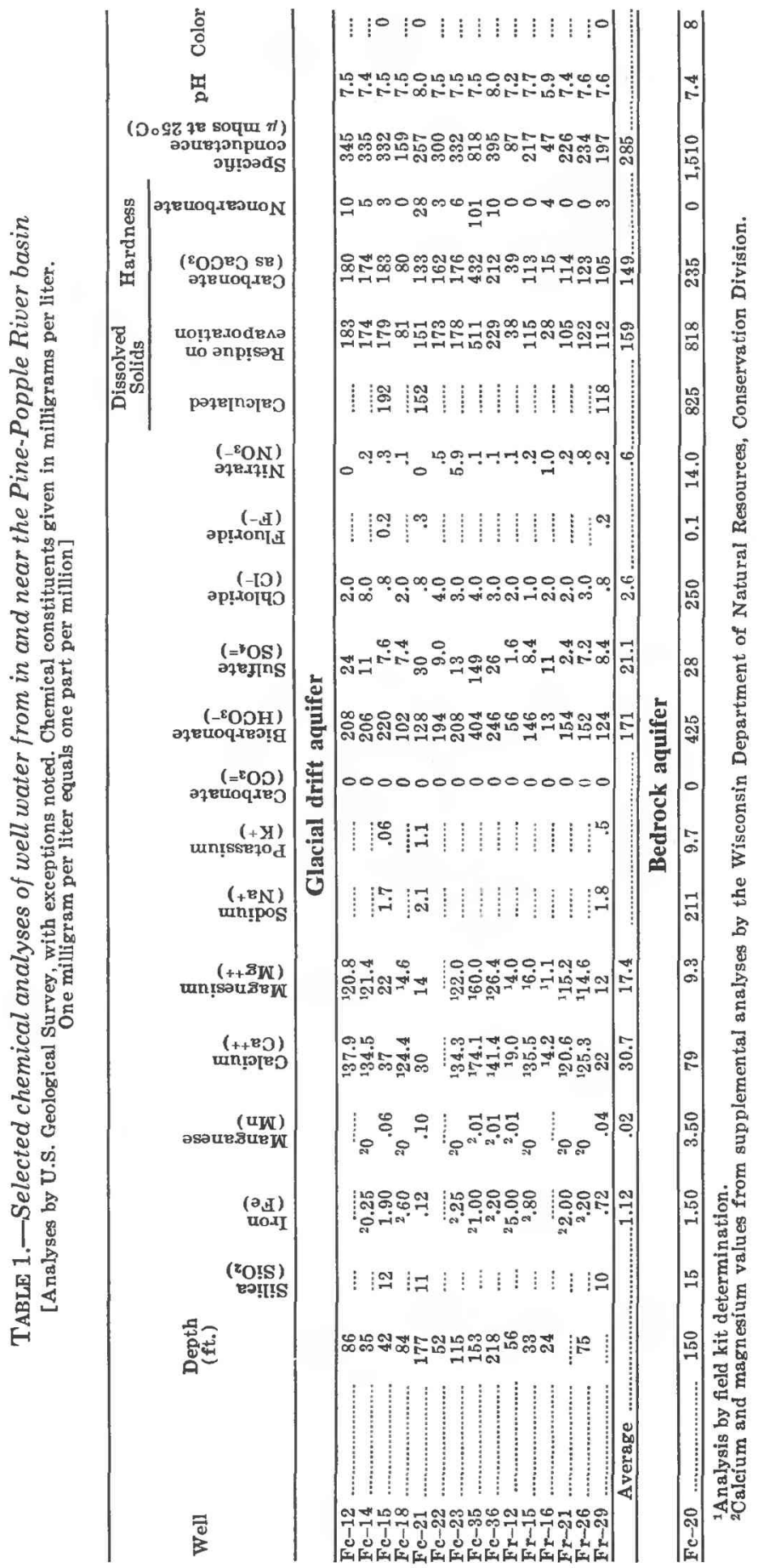




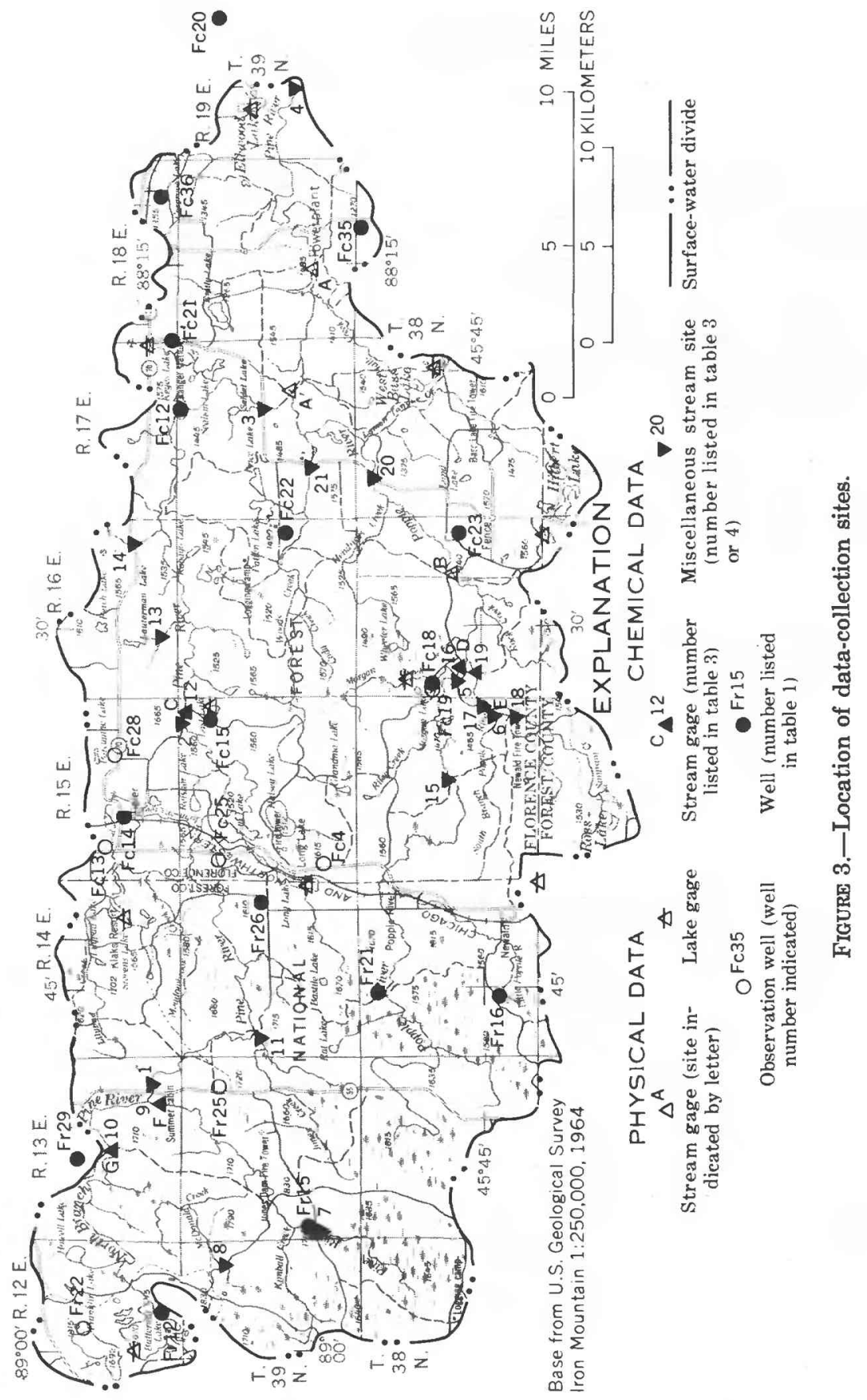


color water and cause staining, and therefore are local problems. Iron and manganese may be removed from water by chemical or physical processes.

Small quantities of highly mineralized water may exist in the bedrock of the basin. Saline water was found during ervloratory drilling in the Florence-Commonwealth iron mining distrist (Weidman and Schultz, 1915, p. 329). The last entry in table 1 is from a well just outside the study area. This well is finished in Badwater Greenstone (pl. 1); its water is much more highly mineralized than water from glacial drift and has a disproportionate ircrease in chloride and sodium. This water does not circulate and mix with the water in the drift and, thus, does not affect present ground- or surface-water supplies.

Existing chemical analyses do not indicate the presence of groundwater pollution. Only one well finished in the glacial drift aquifer, Fc-23 (table 1), has water with a nitrate content grester than $1.0 \mathrm{mg} / \mathrm{l}(5.9 \mathrm{mg} / \mathrm{l}$, which is within the safe limit for human consumption). It is not known if this nitrate content is ratural or induced from surface sources. Further development for human activities, including the installation of privies and septic tanks, may increase the nitrate and phosphate concentrations of ground water. Pollutants introduced into ground water will move along groundwater flow paths and ultimately discharge to surface water.

\section{SURFACE WATER}

Surface water is a renewable resource that is replenished by precipitation and ground-water discharge. In evaluating the hydrology of this basin, quantitative and qualitative determinations of surface water were made.

Abundant surface water of generally good quality occurs in streams, lakes, and wetlands in the Pine-Popple River basin. This resource is widely distributed and is used primarily for recreation. Wetlands occur mostly in the headwaters areas of streams in the western and southwestern parts of the basin. Lakes are distributed throughout the central and western parts. A reservoir impounds water in the lower reaches of the Pine River.

The Pine River varies in width, depth, bottom conditions, and gradient as does the Popple River. For gradient profiles, se? figure 2.

In the headwaters area of the Pine River main stem, the stream width ranges from 15 to 60 feet; stream depth ranges from 1 to 5 feet. Bottom conditions may be muck, silt, sand, cobbles, or boulders. The character of the stream ranges from shallow riffles and moderate currents to deep, quiet pools.

The North Branch Pine River, which is also in the headwaters of the Pine River, flows across a sandy area. Here currents tend to be 
moderately swift, and sandy riffles are common. Stream witth ranges from 4 to 40 feet, and stream depth ranges from $1 / 2$ to 5 feet.

The Pine River, from the confluence with the North Branch Pine River to the confluence with the Popple River, ranges in width from 20 to 100 feet and in depth from 1 to 6 feet. Here the stream has slow, deep pools to rapid white water flowing over boulders and rubble.

The Popple River main stem ranges in width from 12 to 100 feet and in depth from one-half to 5 feet; it may have deep, quiet pools over silt or mud bottoms or shallow riffles over sand. The main stem of the Popple River has reaches of swift water flowing over boulders and rock outcrops. The South Branch Popple River ranges in width from 8 to 53 feet and in depth from 1 to 5 feet.

In the Pine River, from the confluence with the Popp'e. River to its mouth, the stream may be as wide as 150 feet, and pools may be as deep as 8 feet. In this reach, bottom materials are generally silt, sand, and gravel.

Water may enter the streams or the basin system in two ways: as direct runoff of precipitation or as ground-water contribution to streamflow (base runoff).

Direct runoff is dependent on many variables. If precivitation is from rainstorms, runoff is regulated by the intensity and duration of rainfall, the topography, the infiltration capacity of the soil, the antecedent soil-moisture conditions, and the types of vegetative cover. If runoff is from snowmelt, in addition to the above, air temperature, frost depth, and the amount of snow accumulated on the ground are also controlling factors.

The flows of the Pine and Popple Rivers, like the flor's of other streams in the region, vary seasonally. Flow is affected by spring ice breakup, distribution of rain, ice cover, and the modifying effects of wetland storage.

Ice formation begins in early or mid-November, and the streams remain ice covered until melting occurs, usually around the beginning of April. The large accumulations of ice that form in the flat headwater areas create heavy ice flows in early spring.

Characteristically, monthly mean discharge is greatest, in spring and summer and lowest in winter. The long-term (1924-67) streamflow record of the Pine River at site A shows an average flow of $420 \mathrm{cfs}$ (cubic feet per second). The flow equaled or exceeded $5 \mathrm{C}$ percent of the time for the period of record was $312 \mathrm{cfs}$ (fig. 4), and during 25 percent of the time was $550 \mathrm{cfs}$. Figure 4 shows the average flow for each month. The maximum daily flow was 4,380 cfs on April 9, 1929.

Streamflow is the most easily and accurately measurec. portion of the hydrologic cycle. Because a drainage system gathers water from 

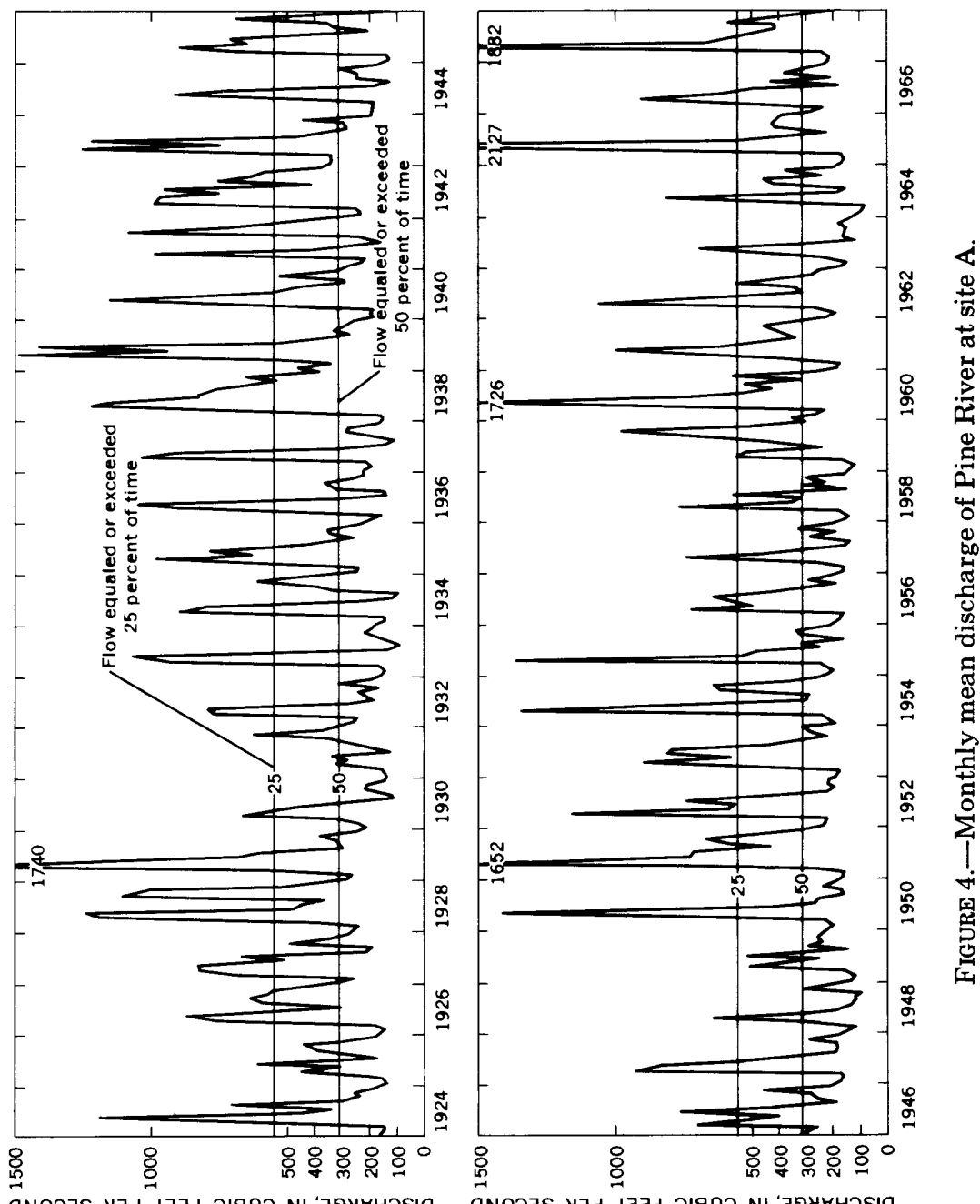

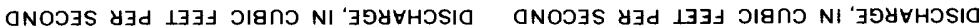


a wide area, an analysis of streamflow may serve to identify other hydrologic parameters existing in a drainage basin.

\section{FLOW DURATION}

A flow-duration curve combines base and direct runoff as a means of determining the hydrologic characteristics of an area. It shows the percentage of time that specified discharges were equaled or exceeded during a given time period without regard to their sequence of occurrence. The shape of the curve reflects the cumulative effects of geology, climate, and the physiographic features of the basin. In general, a curve with a flat slope indicates significant surface- or grc'und-water storage which tends to equalize the flow over a long period of time; a curve with a steep slope denotes a highly variable stream with less storage and high peak runoff. The upper part of the dure tion curve for durations less than 50 percent of the time is generally influenced mostly by direct runoff, because releases from natural storage are small compared with flood discharges. In the lower part of the duration curve for durations that occur more than 50 percent $c^{f}$ the time, releases from natural storage become more apparent and control the shape of the curve.

The streamflow record for 1914-23 represents natural streamflow (measured at site $\mathrm{A}^{\prime}$, fig. 3). A powerplant was installed $\mathrm{c} n$ the Pine River near its mouth in 1922 (site A, fig. 3), 5 miles below site $\mathrm{A}^{\prime}$. Since 1923, streamflow records are obtained from electrical generation figures of the powerplant, which represent near-natural flow.

An examination of the long-term flow duration curves of the Pine River at sites $\mathrm{A}$ and $\mathrm{A}^{\prime}$ indicate that the curves are almost. identical. Except for the duration period of over 95 percent (fig. 5), the curve can be considered to represent the natural flow characteristics of the Pine River. The duration period of over 95 percent represents powerplant regulation.

Although the runoff at the Pine River powerplant was above average during 1967 (fig. 6), the shape of the curve is similar to that of the long-term average. The steepness of the upper end of the curve for 1967 was caused by above-average direct runoff.

The above-average runoff during the spring of 1967 was attributed to snowmelt. Snow surveys made in the winter of 1966-67 indicated that approximately 27 inches of snow, representing 5 inches of water, was on the ground at the end of March 1967. A sudden warmup at the beginning of April caused the snow to melt, resulting in above-normal runoff. The runoff for April (4 inches) was the highest recorded for the Pine River during 1914-67 (fig. 7).

\section{FLOODS}

Flooding is seldom a problem because the basin is urdeveloped. When high flows occur, very little damage results, becaus? there are 


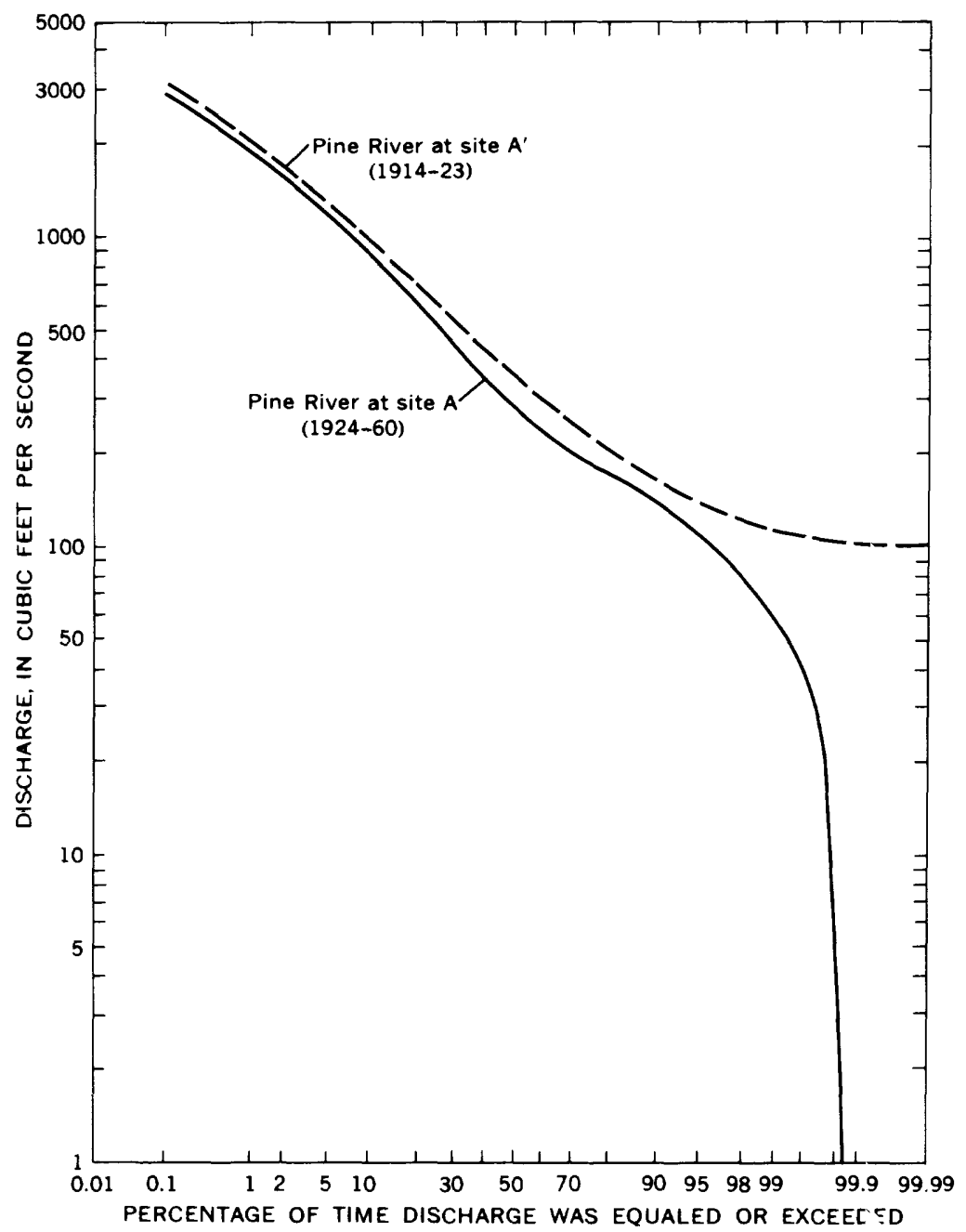

Figure 5.-Duration curves of daily flow of the Pine River at sites A and $A^{\prime}$. From Young (1965).

few structures on the flood plains. Occasionally ice flows or the scouring action of water do some damage to bridges, but high water generally passes without any significant monetary loss.

Many maximum daily peak flows in the basin occur in late March or early April. These flows usually are a result of spring rains and melting snow. The slow melting of snow in forested areas extends the period of direct runoff. Direct runoff decreases if frost is o'it of the soil at spring breakup.

The greatest monthly mean discharges occur from late spring to midautumn, when rainfall is high and storms are comr`on. For 


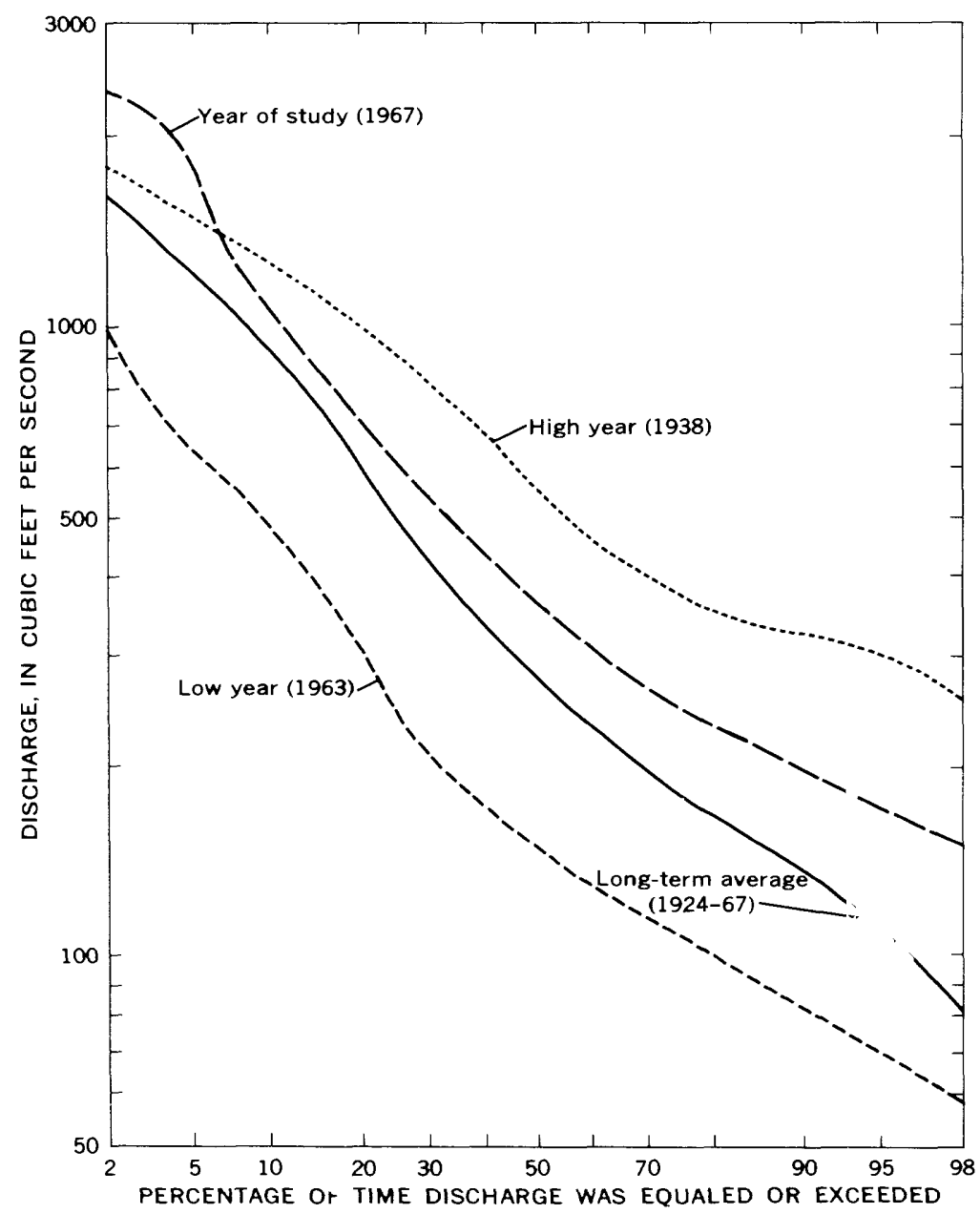

Figure 6.-Duration curves of daily flow of the Pine River $a^{t}$ site A.

Partly from Young (1965).

example, the monthly mean discharge was $2,127 \mathrm{cfs}$ in May 1965 (fig. 4).

\section{LOW FLOW}

The lowest streamflows in the basin generally occur in winter. For example, during November through March 1964, flow on the Pine River declined to less than $100 \mathrm{cfs}$ (fig. 4). Periods of low flow are also common during summer. Summer low flows in the basin generally occur from mid-July to mid-September, a period when evapotranspiration exceeds precipitation.

Low flows of streams in the basin are not uniform areally because of differences in the hydrologic properties of the drift. A profile of 


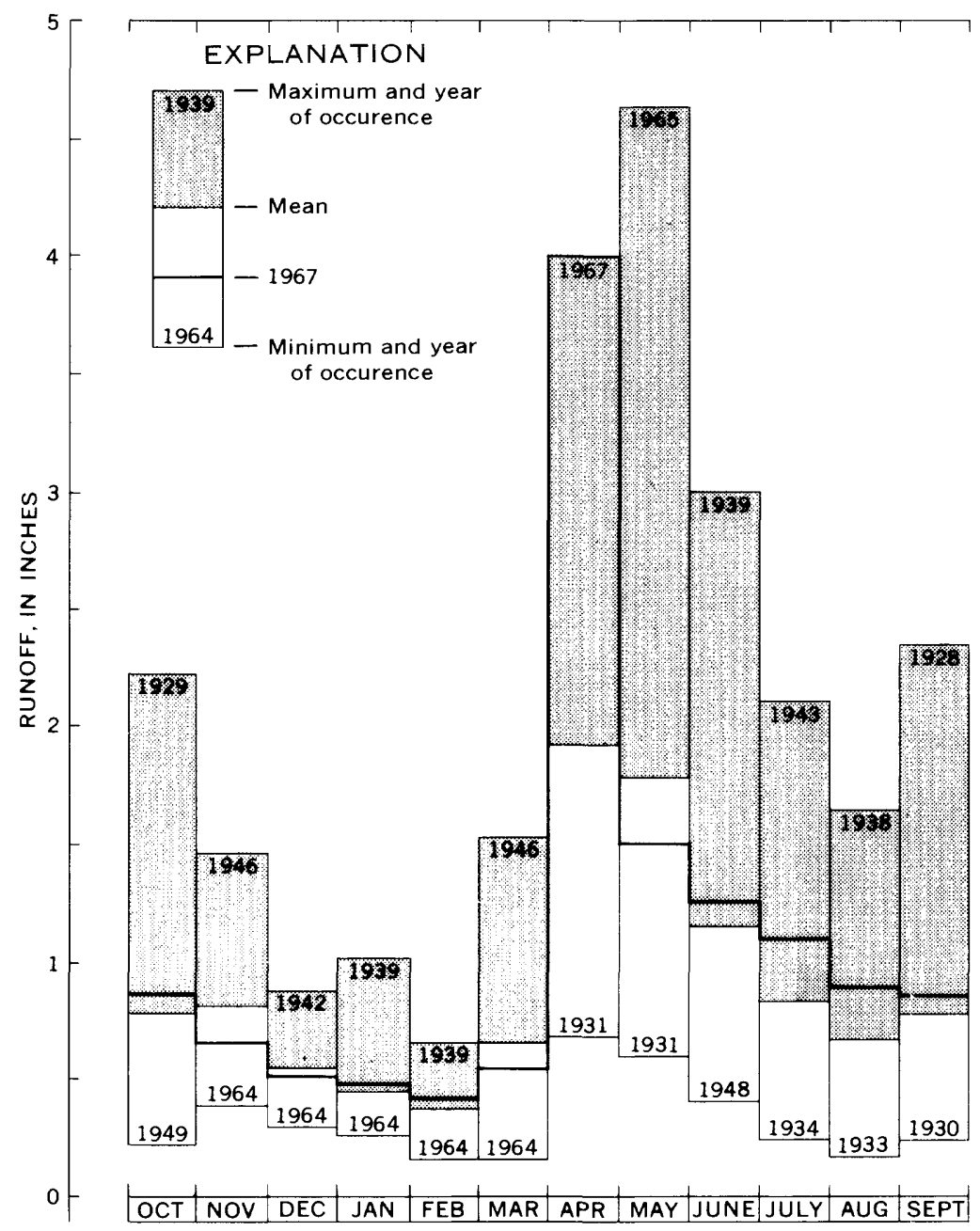

Figure 7.-Maximum and minimum monthly runoff of Pine River at site A.

stream accretion under low-flow conditions is show in figure 8.

Streamflow accretion of the Pine and Popple Rivers averages about 2-3 cfs per stream mile; however, variations occur because of differences in geology. Areas of greatest streamflow accretion occur on the Pine River from Lauterman Creek to the mouth, and most of the ground water comes from drift deposits adjacent to the river. Upstream from Lauterman Creek, water is primarily contributed from ground-water inflow to tributaries of the Pine River, and the accretion rate generally is uniform.

Ground-water accretion to the Popple River is small from the headwaters to Riley Creek (less than 2 cfs per mile), but accretion is large 


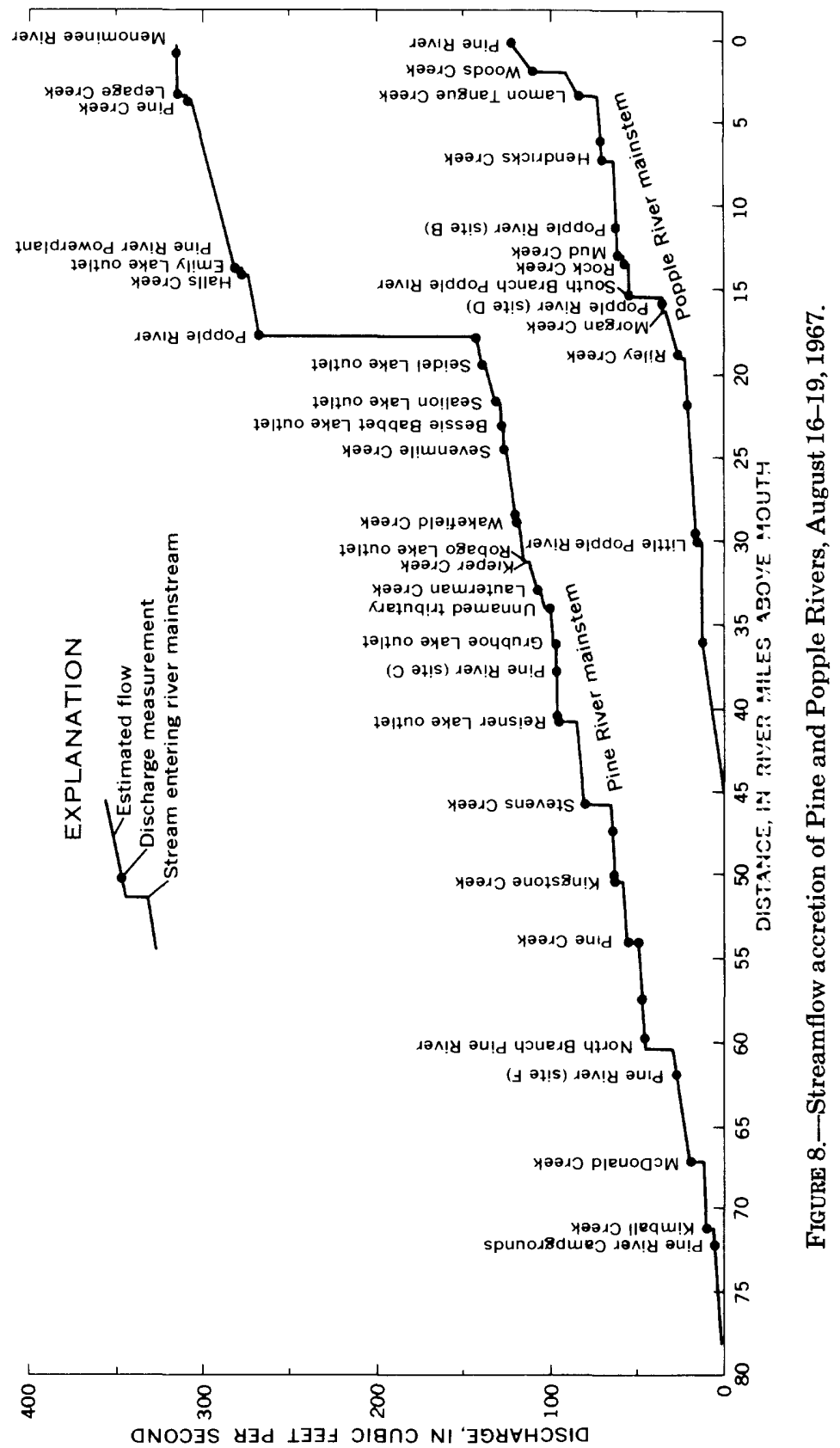


from Riley Creek to the junction with the Pine River. Tro largest rates of accretion occur between Riley and Morgan Craeks and between Lamon Tangue Creek and the Pine River ( $4-5 \mathrm{cfs}$ per mile).

\section{LAKES}

Approximately 70 lakes are scattered across the Pine-Popyle basin. These lakes occupy individual depressions on an uneven glaciated landscape. Many occur in depressions left by melted blocks of ice. All are connected to the water table, and all were formed where the water table crops out above the land surface. None of the lakes are perched.

Most lakes in the basin are in areas of outwash or end moraine. The greatest number of lakes is in the eastern (end moraine) part of the basin. However, these lakes are quite small. The larger, more prominent lakes are in the central and northwestern (outwash) parts of the basin.

The lakes are of two types: drainage lakes (having surface outlets) and seepage lakes (having no discernible surface outlet). Of the 53 drainage lakes in the basin, 11 of them also have inlets. Seventeen lakes are seepage lakes.

The size of named lakes in the basin ranges from 10 to 1,292 acres. Not all lakes have had their maximum depth determined. Known maximum depths range from 4 to 74 feet. Characteristics of selected named lakes are shown in table 2.

Lake stages fluctuate with changes in the water table. From November 1966 to May 1968 the greatest lake-stage fluctuation was about 1.00 foot. The least change during this period was 0.35 foot. Water levels in lakes in the basin tend to be highest following spring breakup, when snowmelt and spring rains recharge aquifers.

\section{SURFACE-WATER QUALITY}

Surface water in the basin, like ground water, is a calcium magnesium (hard) bicarbonate type. Surface water is moderately hard $\left(61-120 \mathrm{mg} / 1\right.$ hardness as $\left.\mathrm{CaCO}_{3}\right)$ and is relatively low in total dissolved solids. Sulfate, chloride, and nitrate concentrations are low. Values of $\mathrm{pH}$ range from slightly acid to slightly basic (6.4-8.0). Some surface water, particularly in bogs and streams draining bogs, is highly colored. Temperatures vary seasonally, ranging from $0^{\circ} \mathrm{C}$ $\left(32^{\circ} \mathrm{F}\right)$ to $28^{\circ} \mathrm{C}\left(83^{\circ} \mathrm{F}\right)$.

The quality of streams at low-flow condition. is nearly that of ground water because streams flow across and receive ba $\%$ runoff from the glacial drift aquifer. Chemical analyses of streamflow at lowflow conditions are shown in table 3 .

Chemical analyses of streams under conditions of flow greater than low flow from 15 selected locations are shown in table 4 . At greater 
TABLE 2.-Selected lakes of the Pine-Popple River basin

[Modified from Wisconsin Conservation Department (1964) using recent information of Wisconsin Department of Natural Resources]

\begin{tabular}{|c|c|c|c|c|c|c|c|c|c|c|c|}
\hline \multirow[b]{2}{*}{ Lake and location } & \multirow[b]{2}{*}{$\begin{array}{c}\text { Size } \\
\text { (acres) }\end{array}$} & \multirow[b]{2}{*}{$\begin{array}{c}\text { Maxi- } \\
\text { mum } \\
\text { depth } \\
\text { (ft.) }\end{array}$} & \multirow[b]{2}{*}{$\begin{array}{l}\text { Public } \\
\text { access }\end{array}$} & \multirow[b]{2}{*}{$\begin{array}{c}\text { Com- } \\
\text { mercial } \\
\text { facilities }\end{array}$} & \multicolumn{7}{|c|}{$\begin{array}{l}\text { Varieties of } \\
\text { game fish }\end{array}$} \\
\hline & & & & & 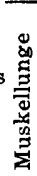 & 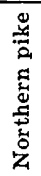 & 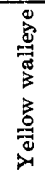 & 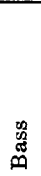 & 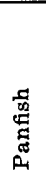 & 焗 & $\begin{array}{l}8 \\
: 0 \\
0\end{array}$ \\
\hline
\end{tabular}

\section{Florence County}

\begin{tabular}{|c|c|c|c|c|c|c|c|c|c|c|}
\hline 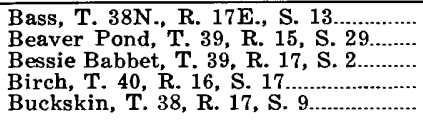 & $\begin{array}{l}47 \\
13 \\
43 \\
10 \\
14\end{array}$ & $\begin{array}{l}42 \\
\cdots \\
\cdots . . \\
\cdots .\end{array}$ & $\begin{array}{l}x \\
x \\
x\end{array}$ & & & & & $\begin{array}{l}X \\
X\end{array}$ & $\begin{array}{l}x \\
x \\
x \\
x \\
x\end{array}$ & $x$ \\
\hline 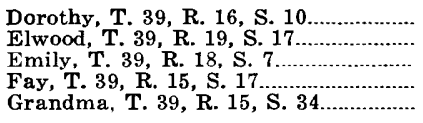 & $\begin{array}{r}18 \\
130 \\
181 \\
263 \\
40\end{array}$ & $\begin{array}{l}\dddot{22} \\
28 \\
18\end{array}$ & $\begin{array}{l}x \\
x \\
x \\
x \\
x\end{array}$ & $\begin{array}{l}x \\
x \\
x\end{array}$ & $x$ & $\begin{array}{l}x \\
x\end{array}$ & $\begin{array}{l}x \\
x\end{array}$ & $\begin{array}{l}x \\
x \\
x\end{array}$ & $\begin{array}{l}x \\
x \\
x \\
x\end{array}$ & \\
\hline 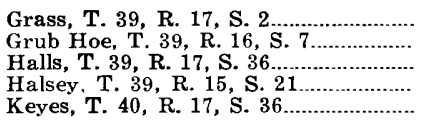 & $\begin{array}{r}43 \\
71 \\
14 \\
510 \\
210\end{array}$ & 10 & $\begin{array}{l}x \\
x \\
x \\
x\end{array}$ & $\begin{array}{l}x \\
x\end{array}$ & & $\begin{array}{l}x \\
x\end{array}$ & $\begin{array}{l}x \\
x\end{array}$ & $\underset{x}{x}$ & $\begin{array}{l}x \\
x \\
x \\
x \\
x\end{array}$ & $x$ \\
\hline 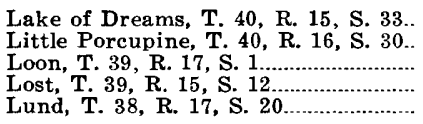 & $\begin{array}{l}49 \\
10 \\
48 \\
88 \\
23\end{array}$ & $\begin{array}{r}15 \\
7 \\
\dddot{45} \\
15\end{array}$ & $\begin{array}{l}x \\
x \\
x \\
x\end{array}$ & & & $\begin{array}{l}x \\
X\end{array}$ & $x$ & $\begin{array}{l}x \\
x \\
x \\
x\end{array}$ & $\begin{array}{l}x \\
x \\
x \\
x \\
x\end{array}$ & \\
\hline 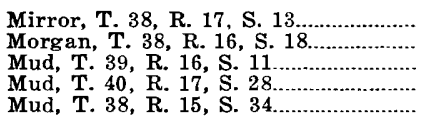 & $\begin{array}{l}10 \\
43 \\
14 \\
15 \\
17\end{array}$ & $\begin{array}{l}10 . \\
10 \\
\cdots . . \\
\cdots . .\end{array}$ & $\begin{array}{l}x \\
x \\
x\end{array}$ & & & & & $\begin{array}{l}x \\
x \\
x\end{array}$ & $\begin{array}{l}x \\
x \\
x \\
x\end{array}$ & \\
\hline $\begin{array}{l}\text { Nona, T. } 38, \text { R. } 16, \text { S. } 31 \ldots \\
\text { Patten, T. } 39, \text { R. } 17 \text {, S. } 18 \\
\text { Perch, T. } 40 \text {, R. } 16, \text { S. } 21 \ldots \ldots \\
\text { Pine River flowage, T. } 39 \text {, R. } 18, \text { S. } 29 \\
\text { Porcupine, T. } 40, \text { R. } 15 \text {, S. } 23\end{array}$ & $\begin{array}{r}14 \\
225 \\
22 \\
130 \\
36\end{array}$ & $\begin{array}{r}6 \\
40 \\
33 \\
33\end{array}$ & $\underset{x}{x}$ & & $x$ & $x$ & $x$ & $\begin{array}{l}x \\
x \\
x \\
x\end{array}$ & $\begin{array}{l}x \\
x \\
x \\
x\end{array}$ & $x$ \\
\hline $\begin{array}{l}\text { Price, T. 39, R. 17, S. } 17 \\
\text { Reisner, T. 34, R. 15, S. } 4 \\
\text { Robago, T. 39, R. 16, S. } 2 \\
\text { Sand, T. } 39, \text { R. 18, S. 13... } \\
\text { Savage, T. 39, R. 16, S. } 11\end{array}$ & $\begin{array}{r}106 \\
96 \\
42 \\
26 \\
138\end{array}$ & $\begin{array}{r}6 \\
6 \\
5 \\
30 \\
10\end{array}$ & $\begin{array}{l}x \\
x \\
x\end{array}$ & & & & & $x$ & $\begin{array}{l}x \\
x \\
x \\
x\end{array}$ & $x$ \\
\hline $\begin{array}{l}\text { Sealion, T. } 39, \text { R. } 17 \text {, S. } 12 \\
\text { Seidel, T. } 39 \text {, R. } 17 \text {, S. } 10 \\
\text { Lauterman, T. } 40, \text { R. } 16 \text {, S. } 29 \\
\text { West Bass, T. } 38, \text { R. } 17 \text {, S. } 14 \\
\text { Wheeler, T. } 38, \text { R. } 16, \text { S. } 8\end{array}$ & $\begin{array}{r}121 \\
40 \\
40 \\
46 \\
40\end{array}$ & $\begin{array}{l}64 \\
2 \ldots \\
25 \\
19 \\
10\end{array}$ & $\begin{array}{l}x \\
x\end{array}$ & $x$ & $x$ & $\begin{array}{l}x \\
x\end{array}$ & $x$ & $\begin{array}{l}x \\
x \\
x \\
x\end{array}$ & $\begin{array}{l}x \\
x \\
x \\
x \\
x\end{array}$ & $x$ \\
\hline
\end{tabular}

Wheeler, T. 38, R. 16, S. 8.................... $40 \quad 10 \quad \times$

\begin{tabular}{|c|c|c|c|c|c|c|c|}
\hline 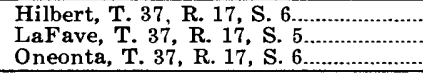 & $\begin{array}{r}298 \\
58 \\
69 \\
\end{array}$ & $\begin{array}{l}38 \\
38 \\
24 \\
\end{array}$ & $x$ & $x$ & $x \times$ & $\begin{array}{l}x \\
x \\
x\end{array}$ & $\begin{array}{l}x \\
x \\
x\end{array}$ \\
\hline
\end{tabular}

\section{Forest County}

\begin{tabular}{|c|c|c|c|c|c|c|c|c|}
\hline $\begin{array}{l}\text { Bastile, T. } 39 \text {, R. } 14, \text { S. } 28 \\
\text { Bose, T. } 40, \text { R. } 12 \text {, S. } 22 \ldots \ldots \ldots \ldots \\
\text { Butternut, T. } 40, \text { R. } 12 \text {, S. } 28 \ldots \ldots \ldots \ldots \\
\text { Forest (Mud), T. } 37, \text { R. } 16, \text { S. } 1 \ldots \ldots \ldots \\
\text { Four Ducks, T. } 39 \text {, R. } 12 \text {, S. } 4 \ldots \ldots \ldots \ldots\end{array}$ & $\begin{array}{r}47 \\
23 \\
1,292 \\
94 \\
18\end{array}$ & $\begin{array}{r}\dddot{29} \\
42 \\
9 \\
20\end{array}$ & $\begin{array}{l}x \\
x \\
x \\
x\end{array}$ & $x$ & $\frac{x}{x} x$ & $\begin{array}{l}x \\
x \\
x \\
x\end{array}$ & $\begin{array}{l}x \\
\dot{x} \\
x \\
x\end{array}$ & \\
\hline $\begin{array}{l}\text { Franklin, T. } 40, \text { R. } 12 \text {, S. } 21 \ldots \ldots \ldots \ldots \ldots \\
\text { Gertrude, T. } 40, \text { R. } 12 \text {, S. } 28 \ldots \ldots \ldots \ldots \ldots \\
\text { Harmony, T. } 40 \text {, R. } 12 \text {, S. } 33 \ldots \ldots \ldots \ldots \ldots \ldots \\
\text { Harriet, T. } 40 \text {, R. } 12 \text {, S. } 33 \ldots \ldots \ldots \ldots \ldots \ldots \ldots \\
\text { Howell, T. } 40 \text {, R. } 12 \text {, S. } 13 \ldots \ldots \ldots \ldots \ldots \ldots \ldots\end{array}$ & $\begin{array}{r}881 \\
12 \\
58 \\
21 \\
169\end{array}$ & $\begin{array}{l}\cdots . . \\
\cdots . . \\
\cdots \\
\cdots . .\end{array}$ & $x$ & $x$ & & $\begin{array}{l}X \\
\times \\
x\end{array}$ & $\begin{array}{l}x \\
x \\
x \\
x\end{array}$ & $X$ \\
\hline
\end{tabular}


TABLE 2.-Selected lakes of the Pine-Popple River basin-Continued

\begin{tabular}{|c|c|c|c|c|c|c|c|c|c|c|c|}
\hline \multirow[b]{2}{*}{ Lake and location } & \multirow[b]{2}{*}{$\begin{array}{c}\text { Size } \\
\text { (acres) }\end{array}$} & \multirow[b]{2}{*}{$\underset{\substack{\text { Maxi- } \\
\text { depth }}}{\text { (ft.) }}$} & \multirow[b]{2}{*}{$\begin{array}{l}\text { Public } \\
\text { access }\end{array}$} & \multirow[b]{2}{*}{$\begin{array}{c}\text { Com- } \\
\text { mercial } \\
\text { facilities }\end{array}$} & \multicolumn{7}{|c|}{$\begin{array}{l}\text { Varieties of } \\
\text { game fish }\end{array}$} \\
\hline & & & & & 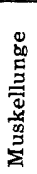 & 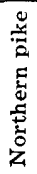 & 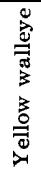 & 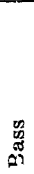 & 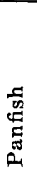 & $\underset{0}{+2}$ & $\begin{array}{l}8 \\
0 \\
0 \\
0\end{array}$ \\
\hline \multicolumn{12}{|c|}{ Forest County-Continued } \\
\hline $\begin{array}{l}\text { Indian Camp, T. } 40, \text { R. } 12, \text { S. } 26 \ldots \ldots \\
\text { Lily Pad, T. } 40, \text { R. 14, S. } 22 \ldots \\
\text { Long, T. } 39 \text {, R. } 14 \text {, S. } 25 . \ldots \\
\text { Mainline, T. } 40, \text { R. } 14 \text {, S. } 33 \ldots \\
\text { McKinley, T. } 40 \text {, R. } 12 \text {, S. } 22 \ldots\end{array}$ & $\begin{array}{r}10 \\
41 \\
329 \\
11 \\
50\end{array}$ & $\begin{array}{r}4 \\
25 \\
20\end{array}$ & $\begin{array}{l}x \\
x \\
x \\
x \\
x\end{array}$ & $x$ & & $x$ & $x$ & $\begin{array}{l}y^{\prime} \\
y^{\prime} \\
y^{\prime}\end{array}$ & $\begin{array}{l}x \\
x \\
x \\
x \\
x\end{array}$ & & \\
\hline $\begin{array}{l}\text { Quartz, T. } 40, \text { R. } 12 \text {, S. } 14 \\
\text { Rogers, T. } 38 \text {, R. } 13 \text {, S. } 2 \ldots \\
\text { Ross, T. } 37, \text { R. 15, S. } 17 \\
\text { Stevens, T. } 40, \text { R. 14, S. } 23 \ldots \\
\text { Sunfish, T. 40, R. } 12 \text {, S. } 14\end{array}$ & $\begin{array}{r}46 \\
16 \\
62 \\
290 \\
20\end{array}$ & $\begin{array}{r}4 \\
10 \\
20 \\
\cdots\end{array}$ & $\begin{array}{l}x \\
x \\
x \\
x \\
x\end{array}$ & $x$ & & $x$ & $x$ & $\begin{array}{l}\rangle^{\prime} \\
y^{\prime} \\
y^{\prime} \\
y^{\prime}\end{array}$ & $\begin{array}{l}x \\
x\end{array}$ & & \\
\hline $\begin{array}{l}\text { Three Johns, T. } 40, \text { R. } 12, \text { S. } 27 \ldots \ldots . . . \\
\text { Two Sisters, T. } 40 \text {, R. 12, S. } 27 \\
\text { Upper Two Sisters, T. 40, R. 12, S. } 26 \\
\text { Wapoose, T. } 40, \text { R. 14, S. } 26 . . . . . . . .\end{array}$ & $\begin{array}{l}46 \\
18 \\
11 \\
31\end{array}$ & $\begin{array}{l}\cdots . . \\
15\end{array}$ & $\begin{array}{l}x \\
x \\
x\end{array}$ & & & & & $\begin{array}{l}x^{\prime} \\
x \\
y^{\prime}\end{array}$ & $\begin{array}{l}x \\
x\end{array}$ & & \\
\hline
\end{tabular}

than low flow, streams generally contain lower concentrations of all dissolved constituents because of dilution of mineralizec' ground water by the addition of less mineralized direct surface runoff.

Specific conductance is generally low in streams that drain wetland and lake areas, whereas conductance is higher in re?ches of streams that receive large ground-water inflow (fig. 8 and pl. 2). The conductivity of water in the main stems of the Pine and Popple Rivers is above 150 micromhos at $25^{\circ} \mathrm{C}$.

Sediment yield at site B (fig. 3) is extremely low, averaging less than 10 tons per square mile per year, which is among the lowest yields in the State (Hindall and Flint, 1970). Sediment yield, which varies throughout the year, is least during low-flow periods and greatest during flood periods. The low sediment yield is attributed to the vegetative cover in the basin and the lack of man's recent alteration of the landscape.

Water samples analyzed for pesticides, BOD (biochemical oxygen demand), and DO (dissolved oxygen) have been taken at sit? B since September 1967 (table 5).

The pesticides (insecticides and herbicides) analyzed for are Aldrin, DDD, DDE, DDT, Endrin, Heptachlor, Heptachlor Epoxide, Lindane, $(2,4-\mathrm{D}),(2,4,5-\mathrm{T})$, and Silvex. No evidence of any of these was found.

Dissolved oxygen, which ranged between 6.5 and $12.0 \mathrm{mg} / \mathrm{l}$ during the monitoring periods, indicates that the stream is healthy and can support trout and other fish. 

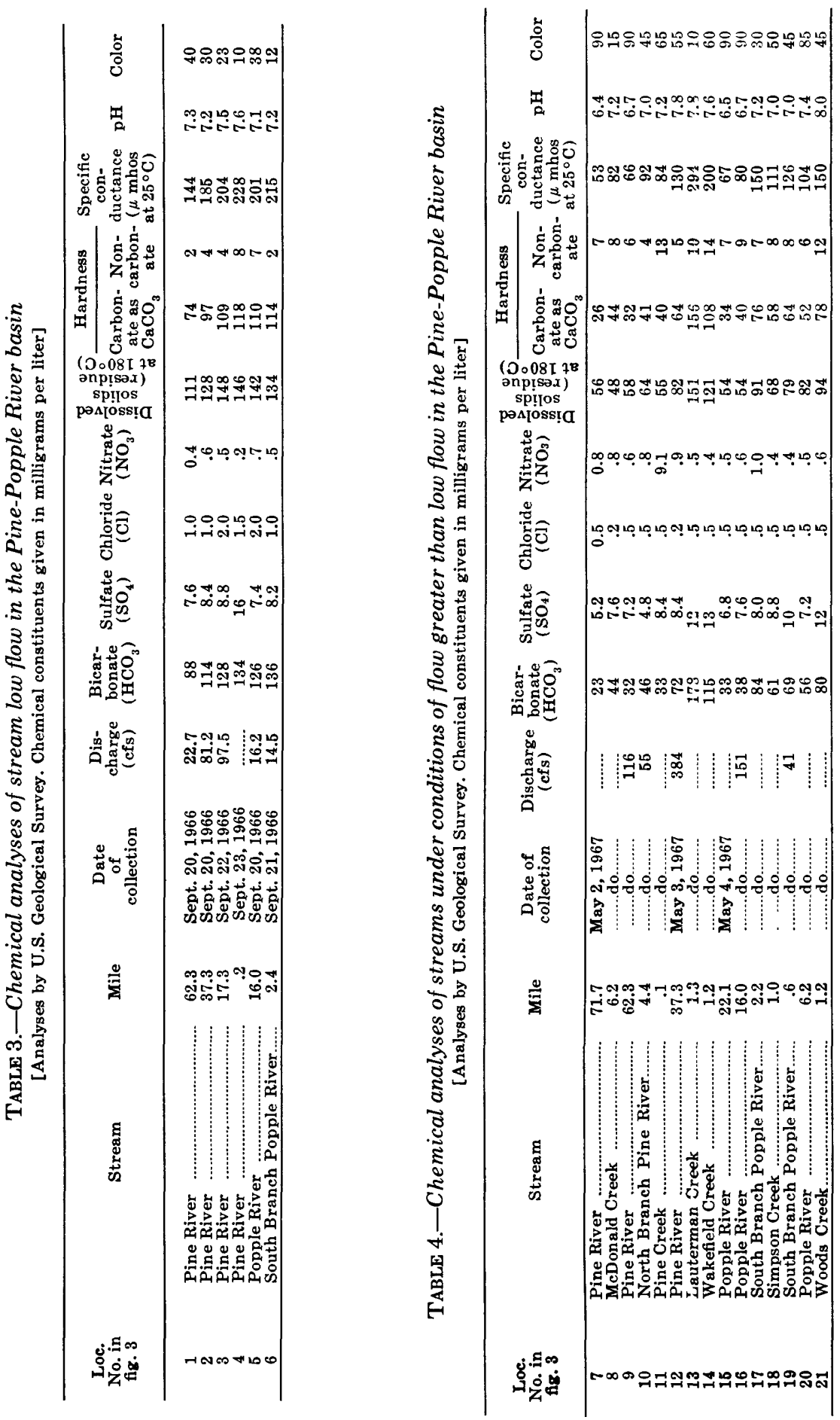
TABLE 5.-Supplemental physical and biological analyses at site $B$ [DO determined by field titration. BOD and coliform samples analyzed in laboratory of Wisconsin State Board of Health]

\begin{tabular}{|c|c|c|c|c|c|c|c|c|}
\hline \multirow{2}{*}{$\begin{array}{l}\text { Date of } \\
\text { collection }\end{array}$} & \multirow{2}{*}{$\begin{array}{c}\text { Time } \\
(24 \mathrm{hr} .)\end{array}$} & \multirow{2}{*}{$\begin{array}{c}\text { Discharge } \\
\text { (cfs) }\end{array}$} & \multirow{2}{*}{ 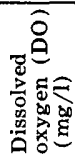 } & \multicolumn{2}{|c|}{ Temperature } & \multirow{2}{*}{ 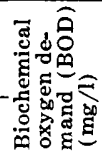 } & \multicolumn{2}{|c|}{$\begin{array}{l}\text { Coliform, membrane } \\
\text { filter (colonies } \\
\text { per } 100 \mathrm{ml} \text { ) }\end{array}$} \\
\hline & & & & $\circ \mathbf{F}$ & ${ }^{\circ} \mathrm{C}$ & & Total & Fecal \\
\hline 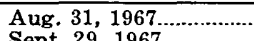 & (n......... & 158 & $\ldots \ldots$ & $\cdots$ & $\cdots$ & 1.8 & 1,300 & $\cdots$ \\
\hline Sept. 29,1967 & 1000 & $\begin{array}{r}180 \\
110\end{array}$ & 86 & $\dddot{34}$ & $\cdots$ & 18 & 300 & $\cdots$ \\
\hline $\begin{array}{l}\text { Oct. } 20,1967 \\
\text { Jan. } 19,1968\end{array}$ & $\begin{array}{l}1000 \\
0940\end{array}$ & $\begin{array}{r}110 \\
44\end{array}$ & $\begin{array}{r}8.6 \\
10.6\end{array}$ & $\begin{array}{l}34 \\
32\end{array}$ & $\begin{array}{l}1 \\
0\end{array}$ & $<.5$ & $\begin{array}{l}300 \\
290\end{array}$ & $\cdots$ \\
\hline 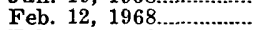 & & 140 & & & $\ldots$ & 5.5 & 100 & $\cdots$ \\
\hline Feb. 29,1968 & 1600 & ${ }^{1} 39$ & 11.6 & 32 & 0 & .......... & ............ & $\cdots$ \\
\hline Mar. 11, $1968 \ldots \ldots \ldots \ldots . . . . .$. & 1200 & 145 & .......... & $\ldots$ & .... & (................ & 100 & $\cdots$ \\
\hline Mar. 18,1968 & 1630 & 182 & 11.3 & $\dddot{33}$ & $\dddot{1}$ & (n................ & ............ & $\cdots$ \\
\hline Apr. 22,1968 & .......... & 1278 & 10.7 & 40 & 4 & (n................... & (..................... & $\cdots$ \\
\hline 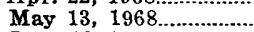 & 0900 & 99 & 10.3 & 53 & 12 & $\ldots \ldots . .$. & ................ & $\cdots$. \\
\hline June 10,1968 & 0900 & 181 & 8.6 & 67 & 19 & & 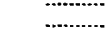 & $\cdots$ \\
\hline June $17,1968 \ldots \ldots \ldots \ldots$ & & 147 & ......... & $\ldots$ & .... & 2.8 & & $\cdots$. \\
\hline July 1,1968 & 0600 & 1533 & .......... & $\cdots$ & $\cdots$ & ......... & 23,600 & \\
\hline July 17,1968 & 1310 & 256 & 6.5 & $\ddot{56}$ & 13 & .................. & 900 & .... \\
\hline Aug. 16,1968 & 1345 & 64 & 9.0 & 66 & 19 & (n............... & & $\cdots .$. \\
\hline Aug. 21,1968 & 1520 & 164 & ........ & .... & $\ldots$ & (n.................... & $2,20 \mathrm{C}$ & $\cdots$ \\
\hline Sept. 19,1968 & 1325 & $\mathbf{1 3 1 2}$ & .......... & $\cdots$ & $\cdots$ & 1.4 & 2250 & $\cdots$ \\
\hline Sept. 20,1968 & 1130 & 307 & 7.6 & 59 & 15 & .......... & & $\ldots .$. \\
\hline Oct. 16,1968 & 1230 & 137 & 8.1 & 61 & 16 & $<1.0$ & $1,40 \mathrm{C}$ & $\cdots$ \\
\hline Nov. 12,1968 & 1230 & 104 & 8.4 & 33 & 1 & $<1.0$ & $42 C$ & 5 \\
\hline Dec. 17,1968 & 1230 & 106 & 12.0 & 32 & 0 & $<1.0$ & 150 & $<5$ \\
\hline Jan. $21,1969 \ldots \ldots \ldots$ & 1300 & 84 & 11.2 & 32 & 0 & $<1.0$ & 50 & 5 \\
\hline
\end{tabular}

1 Average discharge for the day.

2Result subject to question; more than 30 hours had passed between taking sample and determining BOD and coliform.

The low sediment yield and BOD, the low coliform count, and the absence of pesticides indicate that normal human activities have had little effect on the quality of surface water in the Popple River basin. Similar conditions probably exist in the Pine River.

During 1964-67 the temperature range in the Popple River at site $\mathrm{B}$ (fig. 3) was from $\mathrm{O}^{\circ} \mathrm{C}$ to $28^{\circ} \mathrm{C}\left(32-83^{\circ} \mathrm{F}\right.$ ) (fig. 9). Temperatures remained at $0^{\circ} \mathrm{C}$ for most of the winter months. Summer temperatures reached their highest in late July. This record compares well with most other short-term temperature records in the basin. During water year 1967, stream temperature was monitored at 14 sites in the basin. The greatest temperature range in the Popple River was from $0^{\circ} \mathrm{C}$ to $30^{\circ} \mathrm{C}\left(32-86^{\circ} \mathrm{F}\right)$. The smallest recorded range was from $0^{\circ} \mathrm{C}$ to $20^{\circ} \mathrm{C}\left(32-68^{\circ} \mathrm{F}\right)$ in Woods Creek at State Highway 101. The temperature of Woods Creek at State Highway 101 was cooler than the Popple River at site B (fig. 10).

Woods Creek, a stream with a steep gradient, flows beneath a dense canopy of trees and shrubs and receives little sunlight to warm the water. In contrast, the Popple River above site B has a rather flat gradient and flows through broad, flat, open reaches that receive much sunlight. At the time of the low-flow measurement in 1967, Woods Creek yielded $0.42 \mathrm{cfs}$ per square mile, and the Popple River yielded $0.49 \mathrm{cfs}$ per square mile. Because the Popple River received slightly more ground-water discharge, the coolness of Woods Creek is attributed to the lack of sun warming. 


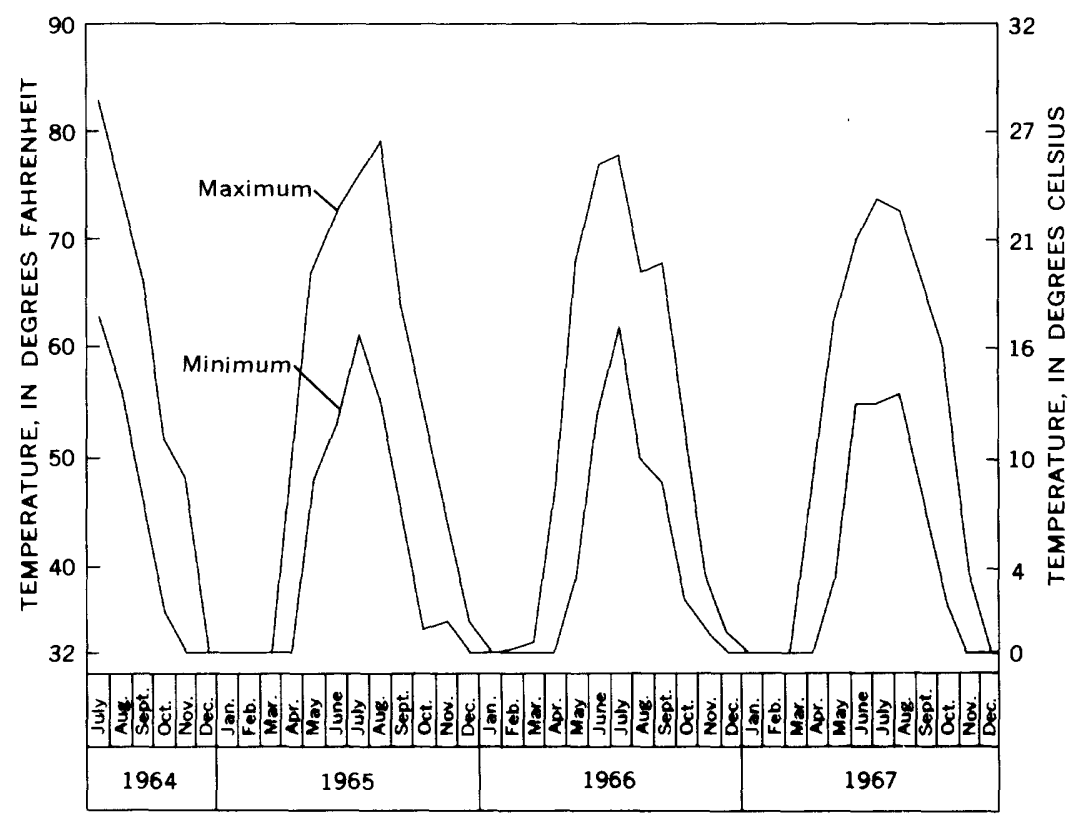

FIGURE 9.-Maximum and minimum monthly stream temperatures of the Popple River at site B.

Cyclic fluctuations, shown in figure 11, indicate the diurnal effects of aquatic plants on dissolved-oxygen levels. After sunse ${ }^{+}$the process of photosynthesis stops, and DO levels decrease overnight. Oxygen levels increase when the sun stimulates the process again.

The highest DO content and the greatest DO fluctuation was on the Popple River at site B, and was due to dense aquatic plant growth above the sampling site. The lowest DO levels and the least DO fluctuation is attributed to a lack of vegetation above the sampling site; the low DO levels are attributed to the lack of veretation and the flat stream gradient, which is not conducive to aeration of the water.

\section{GROUND WATER-SURFACE WATER RELATIONSI'IPS}

Ground water and surface water are closely related and should be considered a single resource. The flow of streams, the stage of lakes, and the existence of wetlands are dependent, to a large part, on ground-water inflow. Factors that influence the availability of ground water influence the availability of surface water. Water-management programs should recognize ground water-surface water relationships.

STREAMS AND THEIR RELATION TO GROUND WATER

During periods of no direct surface runoff, streamflow is maintained by base runoff. Base runoff in the Pine-Popple River basin is an index 


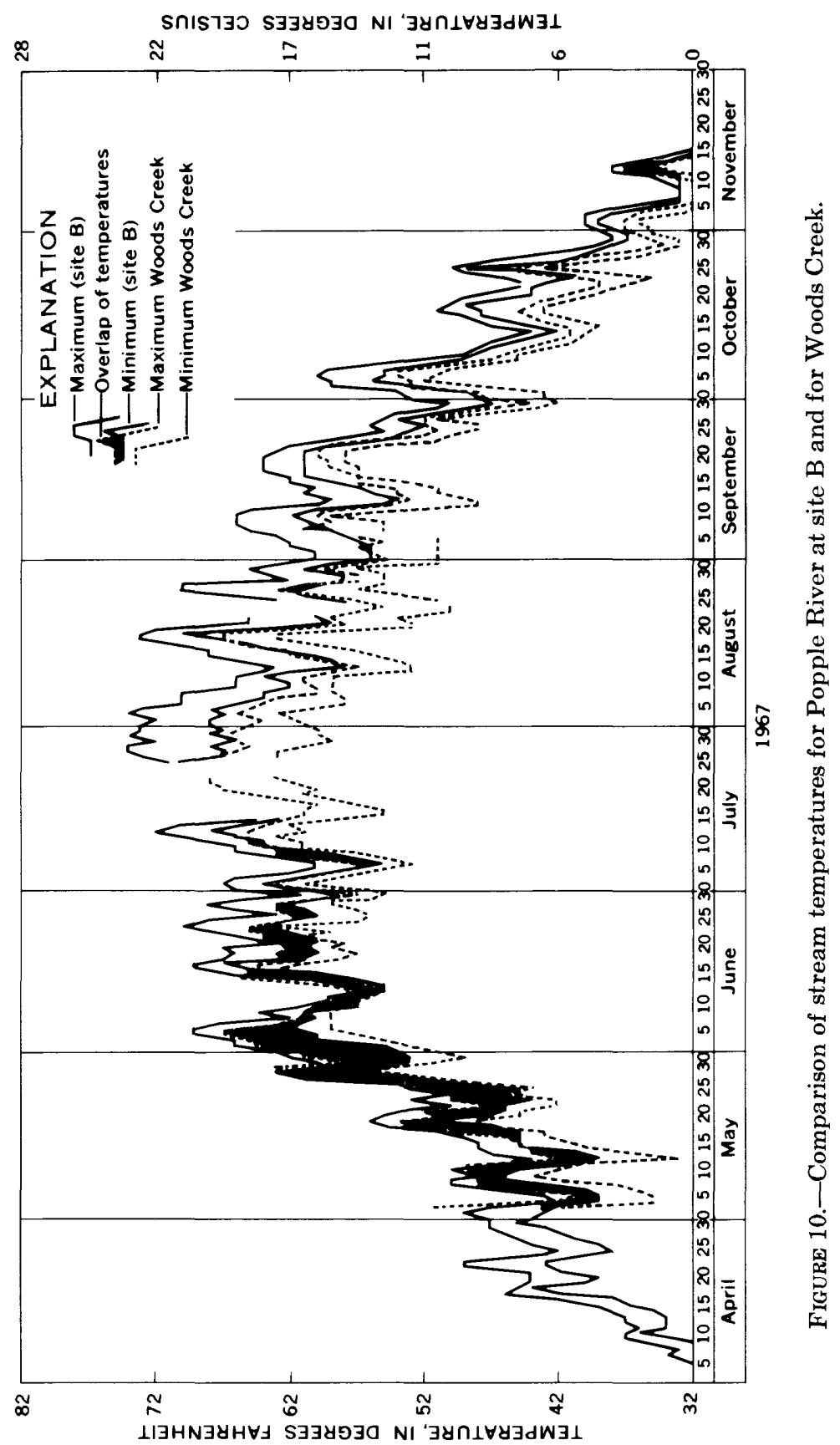



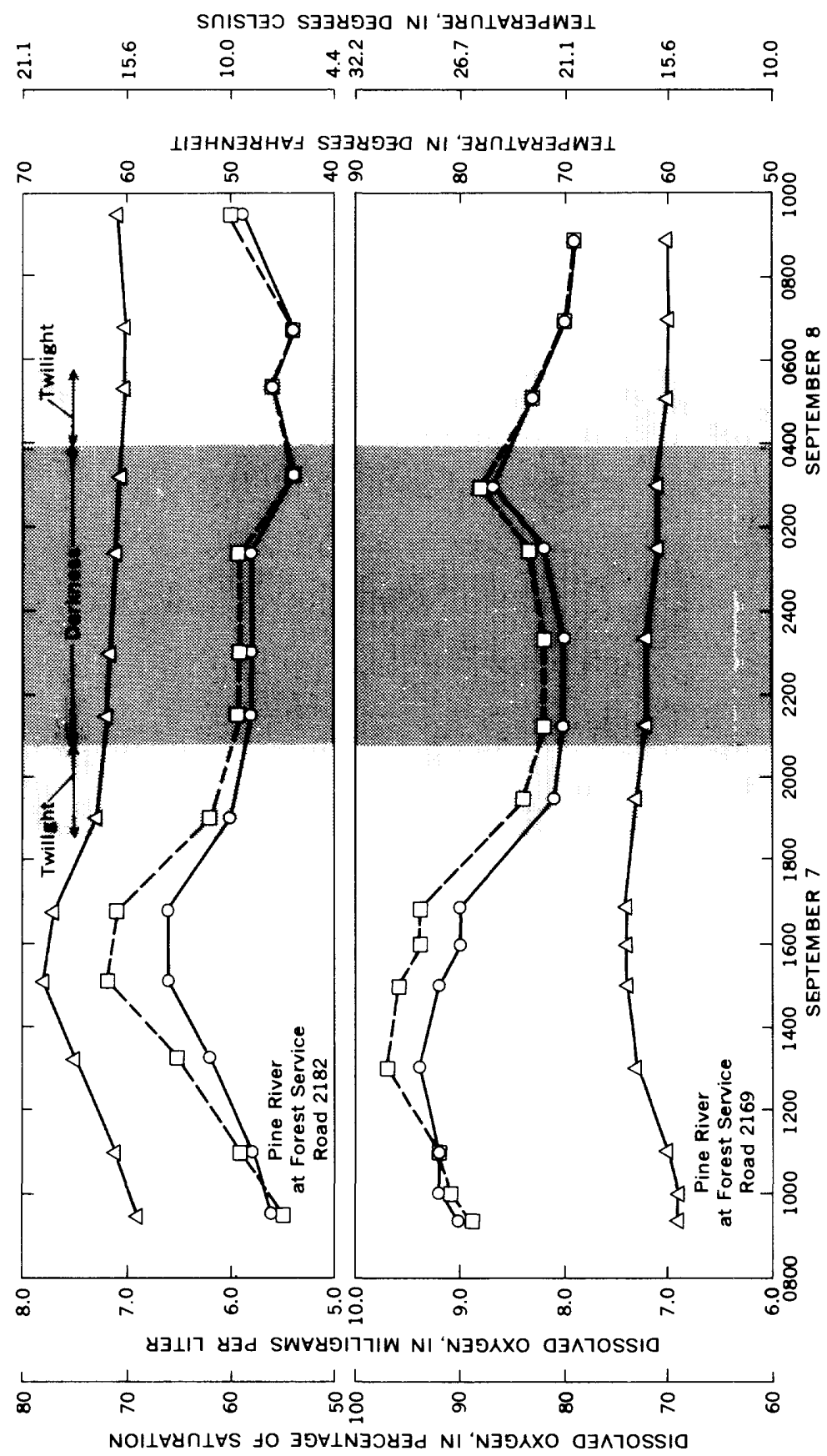


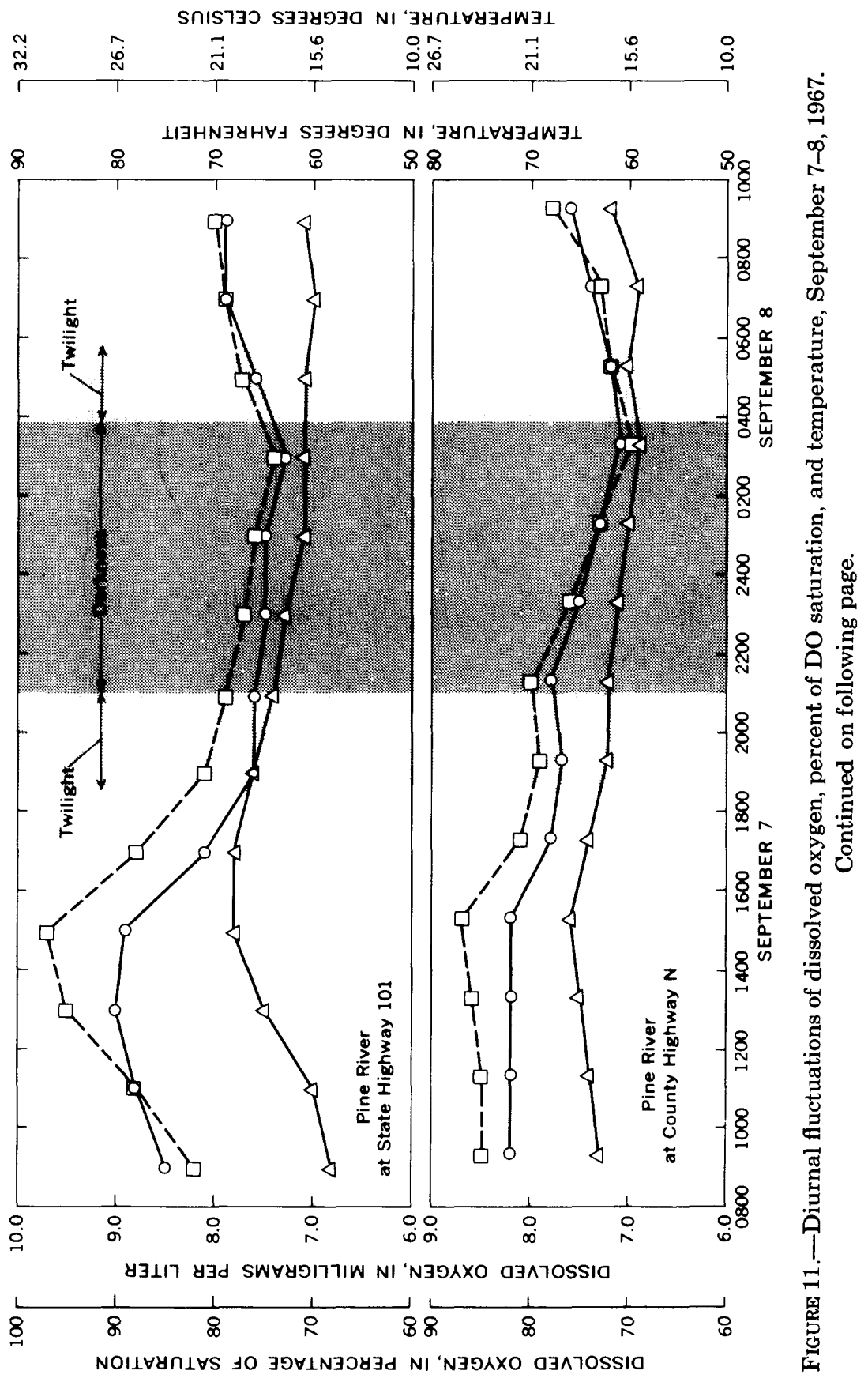



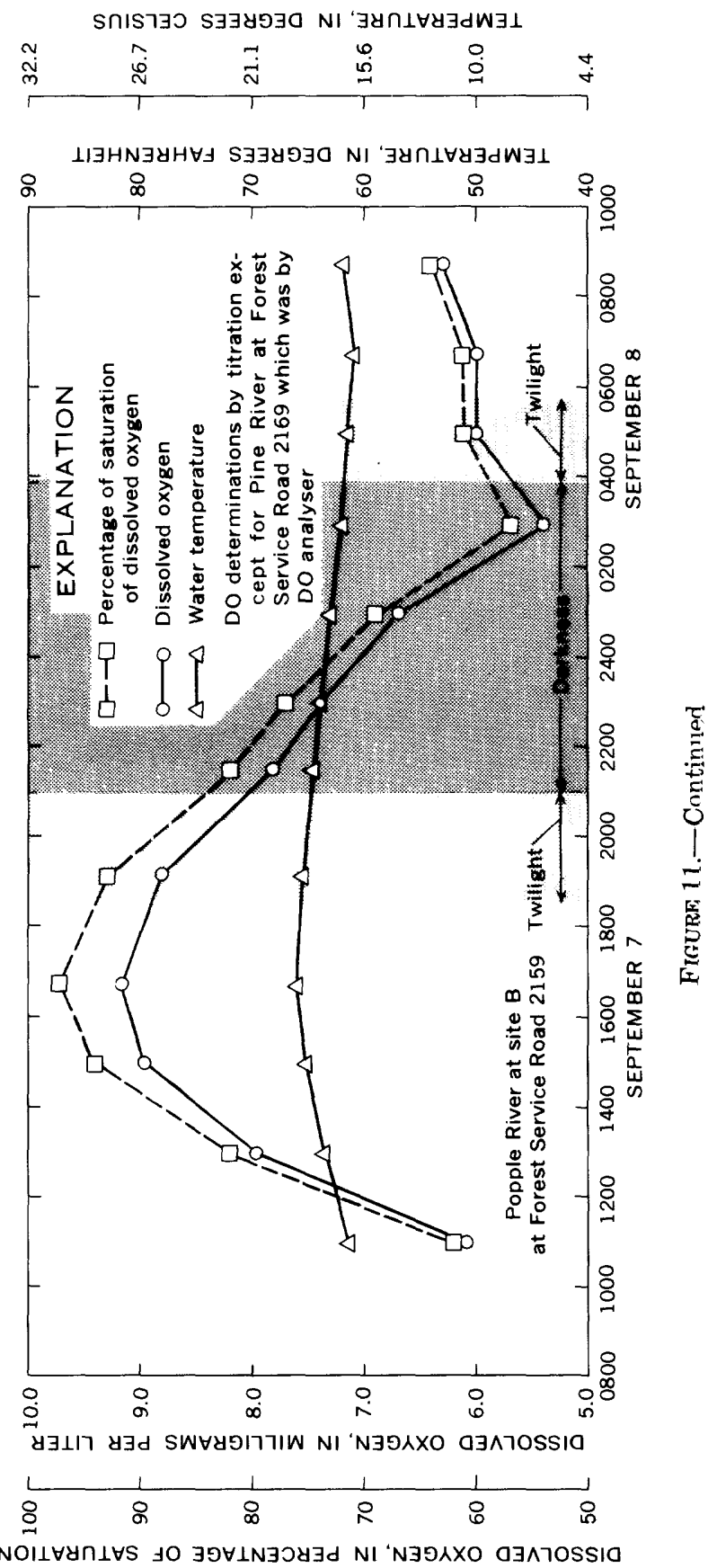
of the water-yielding capacity of the glacial-drift aquifer. The thick saturated sections of highly permeable drift that occur in the westcentral part of the basin release water to the Pine River at higher rates for longer time periods than the thin, less permeable sections that occur near Keyes Lake in the northeastern part.

Figure 12 illustrates the relationship between precipitation, groundwater stage, and base runoff. Unfortunately, these three factors were not recorded at the same site. Site $C$ is about $71 / 2$ miles northeast of well Fc-4, and the precipitation gage at Newald is about $51 / 2$ miles south of well Fc-4. Nevertheless the following are indicated:

1. Ground-water stages respond very quickly to spring me'ting and early spring rainfall;

2. Increased base runoff in streams is a response to high groundwater stages.

Without the restoration of ground-water levels as the result of snowmelt and spring rains, there would be little base runoff to maintain streamflow during dry periods. In addition, base runoff maintains the thermal condition of streamflow essential to a cold-water vild river.

For the analysis of streamflow data, flow-duration curves were drawn for each gaging station for climatic year 1967 (April 1, 1967March 31, 1968). This period was used because it does not separate the low-flow seasons as do the calendar year and the water year. During the climatic year, ground water is recharged by spring snowmelt and rain and then is discharged slowly throughout the remainder of the year, except for periods of minor recharge from rainstcrms. Discharge was expressed as a ratio to mean annual flow to eliminate the effects of drainage area size and differences in mean annual runoff per square mile which occur as a result of irregularities in precipitation over the individual basins.

The flow-duration curves for sites A, B, and C in figure 13 indicate similar streamflow characteristics. Site B (Popple River), however, has slightly higher direct runoff, lower base runoff, and les surfacewater storage than site A (Pine River). The variation between the part of the curve greater than 45 percent between the site $\mathrm{C}$ curve and the site A curve is primarily caused by powerplant regulation.

Flow-duration curves for streams in headwaters compar? groundand surface-water relationships in the basin (fig. 14). These curves indicate two flow characteristics-E, G, and D, F. The Pine River (site F) and the Popple River (site D) have a higher ratic of direct runoff to base runoff and less natural surface-water storage than the North Branch Pine River (site G) and the South Branch Popple River (site $\mathrm{E}$ ). The drainage areas above sites $\mathrm{D}$ and $\mathrm{F}$ are about 35 percent swampland, which increases direct runoff and provides little storage. These swamps are almost entirely forested and contain 


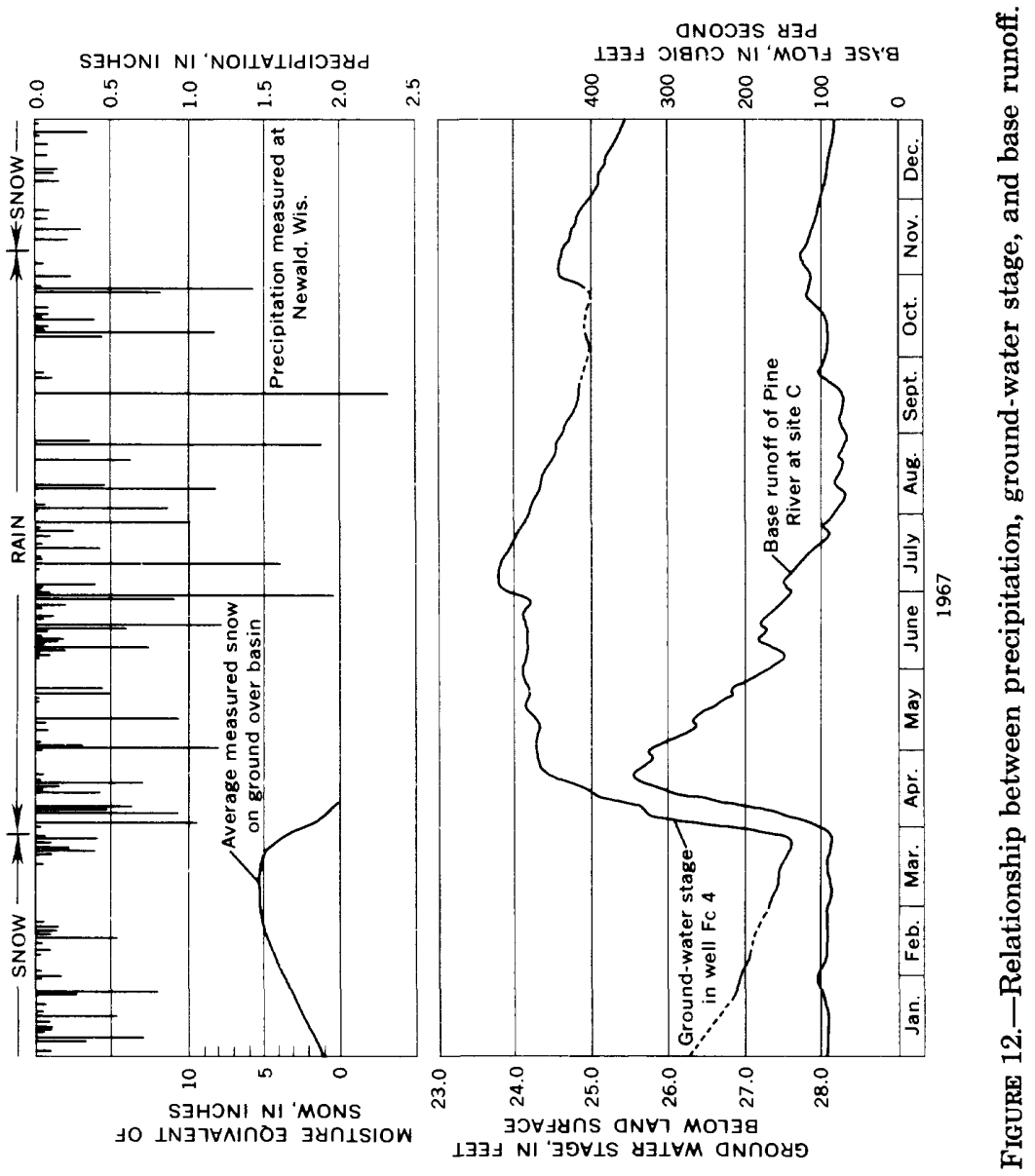




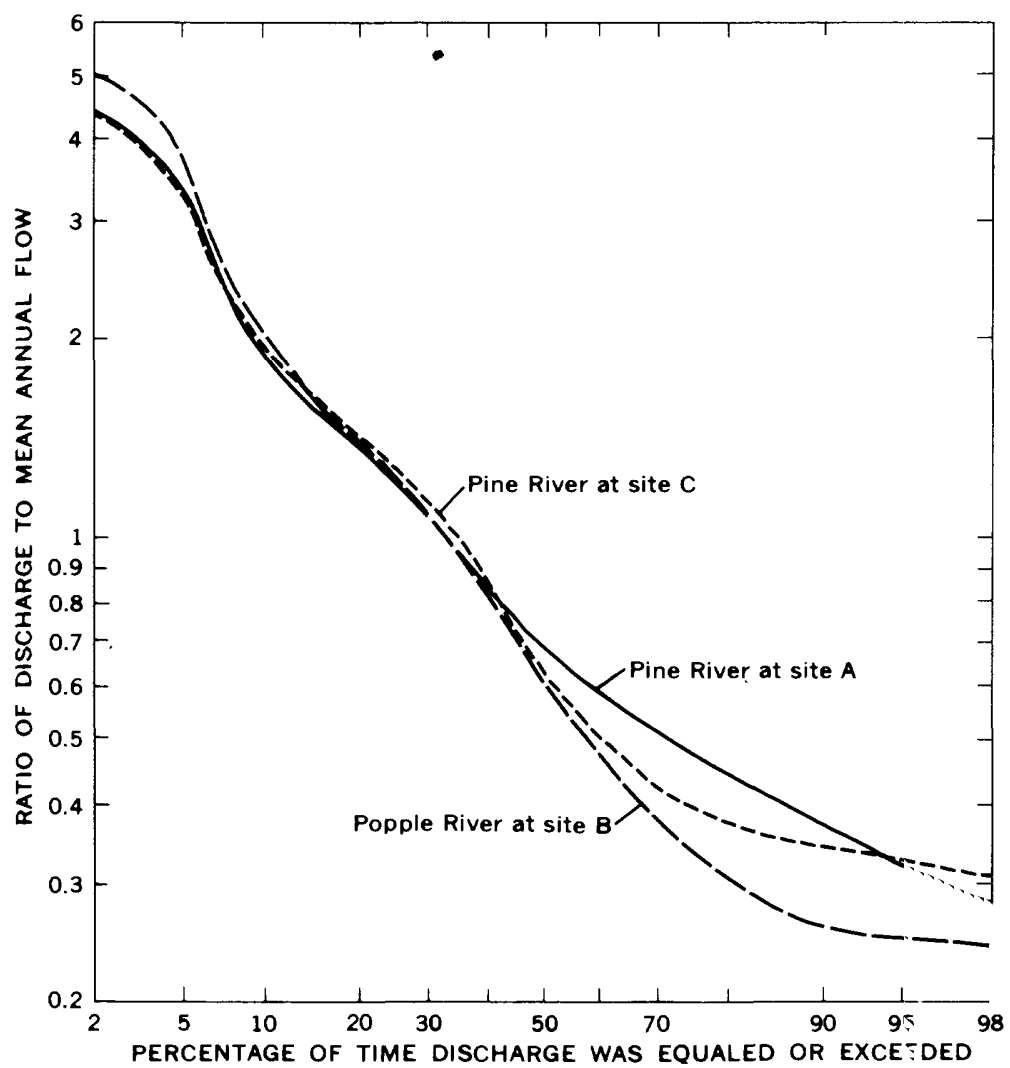

Figure 13.-Duration curves of daily flow of the Pine and Popple Rivers at sites A, B, and C for climatic year 1967 .

decomposed herbaceous peats. In extended drought periods, streamflow in these areas becomes extremely low.

The areas above sites $\mathrm{E}$ and $\mathrm{G}$ contain a higher percentage of permeable sand than the areas above sites $\mathrm{D}$ and $\mathrm{F}$. However, the area above site $\mathrm{E}$ has a large percentage of moss-peat swamp and almost no lakes, while the area above site $G$ has very little swamp but a large percentage of lake area. Lakes and moss-peat swamps in the PinePopple River basin have similar capacities to store and release water; thus, these areas tend to reduce direct runoff and to sustain base runoff.

Base runoff varies annually in the basin. Throughout most of the basin, base runoff in August 1967 was generally twice as much as in September 1966. This generalization did not hold true for the subbasins above station $\mathrm{E}$ ( table 6 ). While the 1967 discharge of Simpson Creek almost doubled, the discharge remained almost the same for the South Branch Popple River above Simpson Creek. 


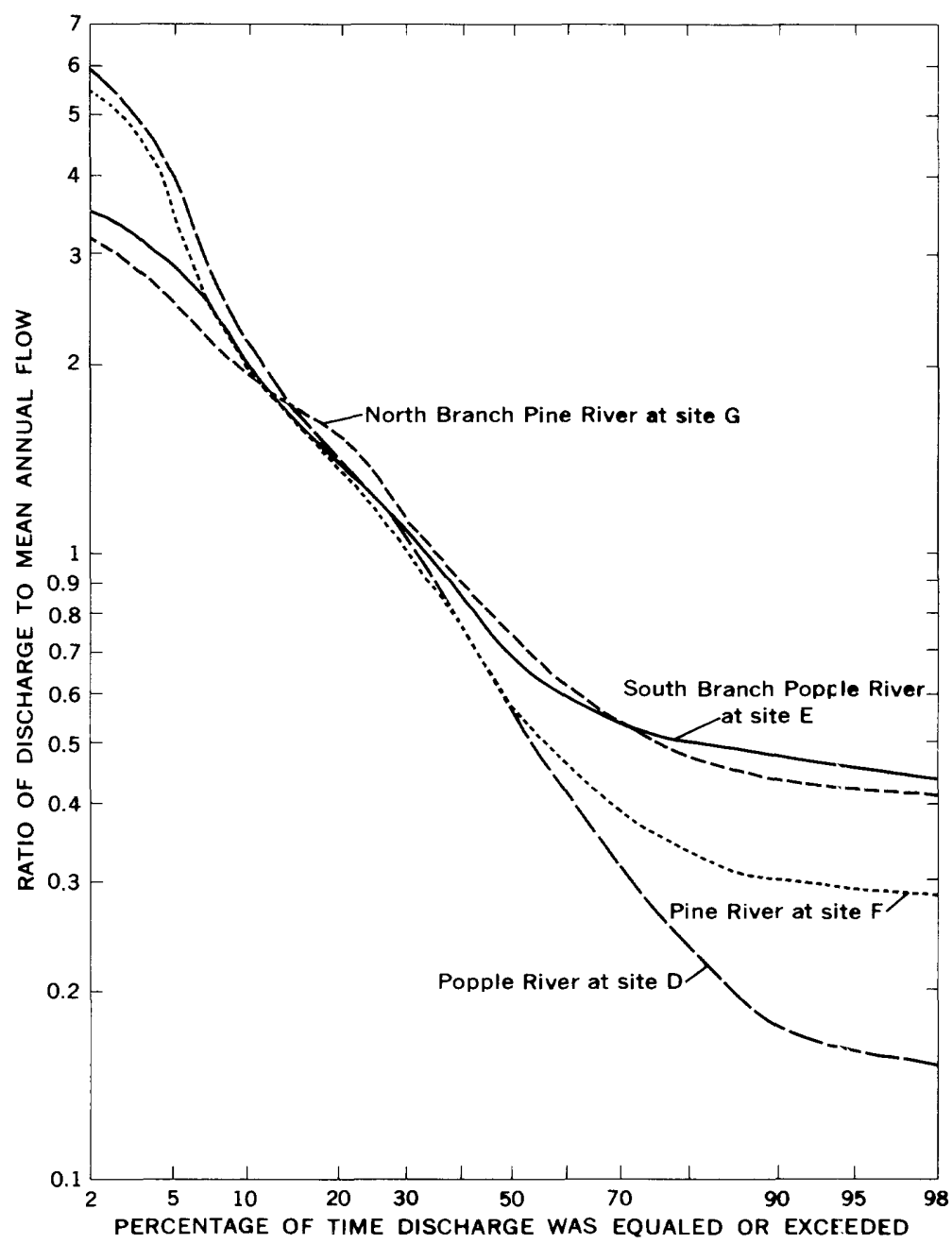

Figure 14.-Duration curves of daily flow of the Pine and Popp'e Rivers at sites D, E, F, and G for climatic year 1967.

The Simpson Creek basin accounts for 63 percent of tr 9 drainage area of station $\mathrm{E}$ and drains moss-peat swamp areas. During periods of high base runoff, the moss-peat reservoir is relatively ful and yields water to streams readily. However, as the porous moss peats drain, the underlying dense, decomposed herbaceous peats tenc' to release water slowly. The South Branch Popple River above Simrson Creek, which has very few swamps (17 percent), maintained almost the same base runoff in both periods. Saturated drift thickross in this area is relatively low, and the swamps are nearly all herbareous peat, which has little capacity to store and release ground water. 
TABLE 6.-Streamflow measurements for South Branch Popple River above Simpson Creek and for Simpson Creek

\begin{tabular}{|c|c|c|c|c|c|}
\hline \multirow{2}{*}{ Stream } & \multirow{2}{*}{$\begin{array}{c}\text { Drain- } \\
\text { age } \\
\text { area } \\
\text { (sq. } \\
\text { mi.) }\end{array}$} & \multirow{2}{*}{$\begin{array}{l}\text { Swamp- } \\
\text { land } \\
\text { (per- } \\
\text { cent) }\end{array}$} & \multirow{2}{*}{ Date } & \multicolumn{2}{|c|}{ Discharge } \\
\hline & & & & cfs & $\begin{array}{l}\text { cfs per } \\
\text { sq. mi. }\end{array}$ \\
\hline $\begin{array}{l}\text { South Branch Popple River } \\
\text { above Simpson Creek....... }\end{array}$ & 10.2 & 17 & $\begin{array}{l}\text { Sept. 21, } 1966 \\
\text { Aug. 18, } 1967\end{array}$ & $\begin{array}{l}8.45 \\
8 . C 2\end{array}$ & $\begin{array}{r}0.83 \\
.79\end{array}$ \\
\hline 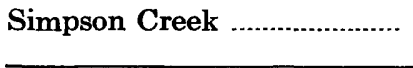 & 18.1 & 34 & $\begin{array}{l}\text { Sept. 21, } 1966 \\
\text { Aug. 18, } 1967\end{array}$ & $\begin{array}{c}5.25 \\
10.1\end{array}$ & $\begin{array}{l}.29 \\
.56\end{array}$ \\
\hline
\end{tabular}

\section{LAKES AND THEIR RELATION TO GROUND WATER AND STF EAMS}

Lakes in the Pine-Popple River basin, like springs and streams, are located where the water table intersects the land surface. The lake surface represents the water table above the land surface. Examples of ground-water movement into and through drainage and seepage lakes are shown in figure 15.

In the northwestern part of the basin, ground water moves from the ground-water divide and discharges into Franklin Lake. Water moves from Franklin Lake (a seepage lake) through perme`ble sand and enters Butternut Lake (a drainage lake). Some ground water also enters Butternut Lake from permeable sand around its reriphery. Water from Butternut Lake drains through an eastern outJet, which is the headwaters of the North Branch Pine River. Within the headwaters area, ground water moves into and through numerous small seepage lakes.

Morgan Lake, a seepage lake in the south-central part of the basin, intercepts ground-water movement from north to south. Water in Morgan Lake reenters the ground and eventually discharges to the Popple River about 1 mile south.

The rate of lake-stage change in seepage lakes does not: coincide with the rate of change in drainage lakes. Figure 16 compares lake stages in Morgan Lake and Butternut Lake. Although Mor «an Lake has an abandoned drainage channel, the lake is a seepage lake. Its water-level trends resemble those of the surrounding water table. This lake receives its initial recharge with the restoration of ground-water levels in spring; following this the lake stage declines at a slow, uniform rate. In contrast, Butternut Lake drains through its outlet, and the lake stage declines more rapidly than the stage of Morgan Lake.

\section{WATER USE}

Man's use of water in the Pine-Popple River basin is of two kindswithdrawal use, which includes a small amount taken from wells for private and public needs, and nonwithdrawal use, which includes recreation and power generation. 


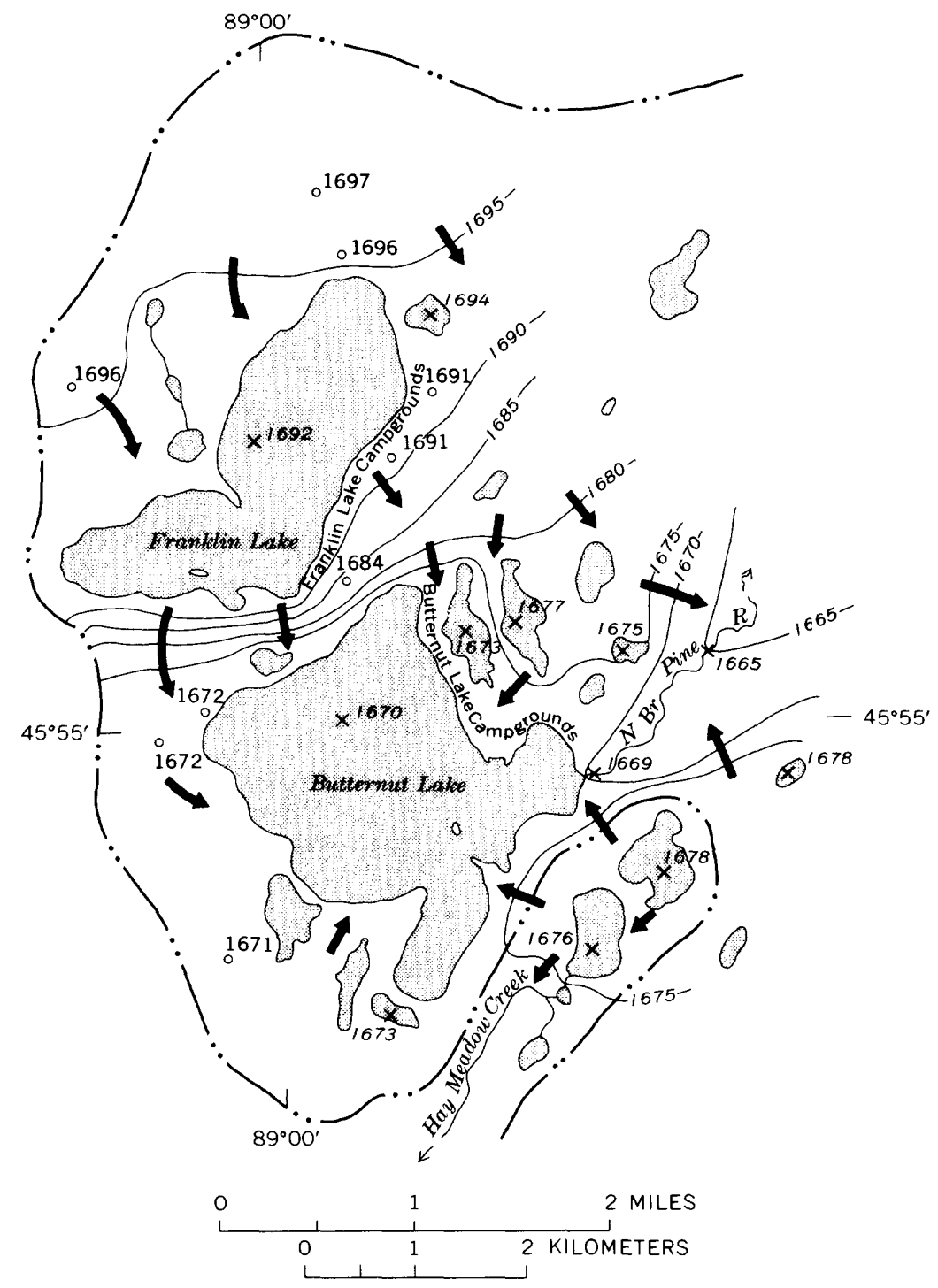

FIGURE 15.-Ground-water movement in and around Franklin, Butternut, and Morgan Lakes.

\section{WITHDRAWAL USE}

Some water is withdrawn from wells around lakes, on carpgrounds, on farms and rural tracts, and in small unincorporated s 3 ttlements. Total withdrawal use is estimated to be about $200,000 \mathrm{~g}$ ] $d$ (gallons per day), which is only 0.7 percent of the average daily runoff at the Pine River powerplant. 


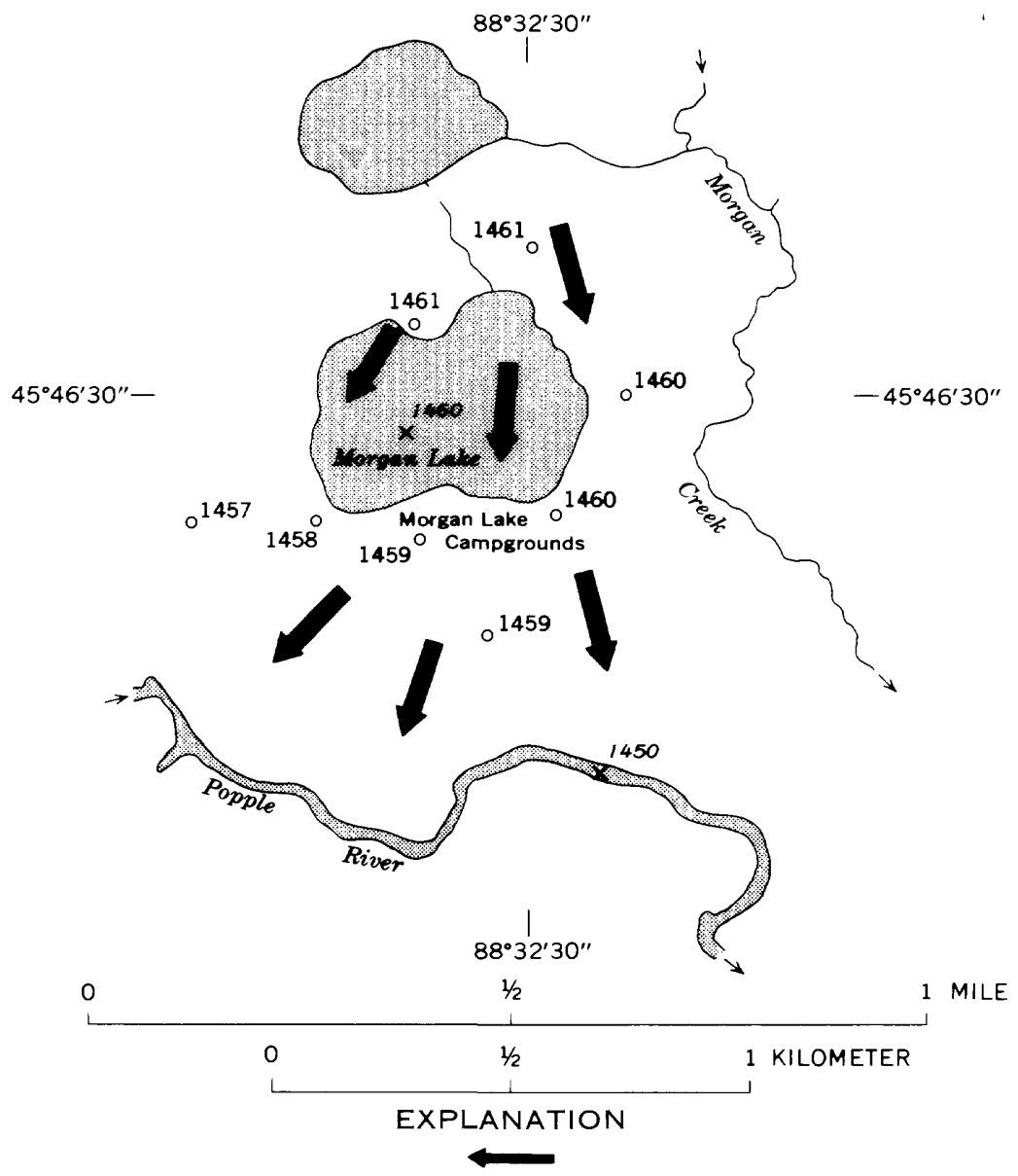

Direction of ground-water movement

$$
\begin{gathered}
\text { Water-table contour } \\
\text { Contour interval } 5 \text { feet } \\
\times^{1677} \\
\text { Water-surface altitude } \\
0^{1460} \\
\text { Water level in well }
\end{gathered}
$$

Above figures are in feet above mean sea level obtained by altimeter or level

Surface-water divide

Most water withdrawn from wells in the basin is returnet to the ground. No water is withdrawn from streams or is dischar red into streams as sewage. 

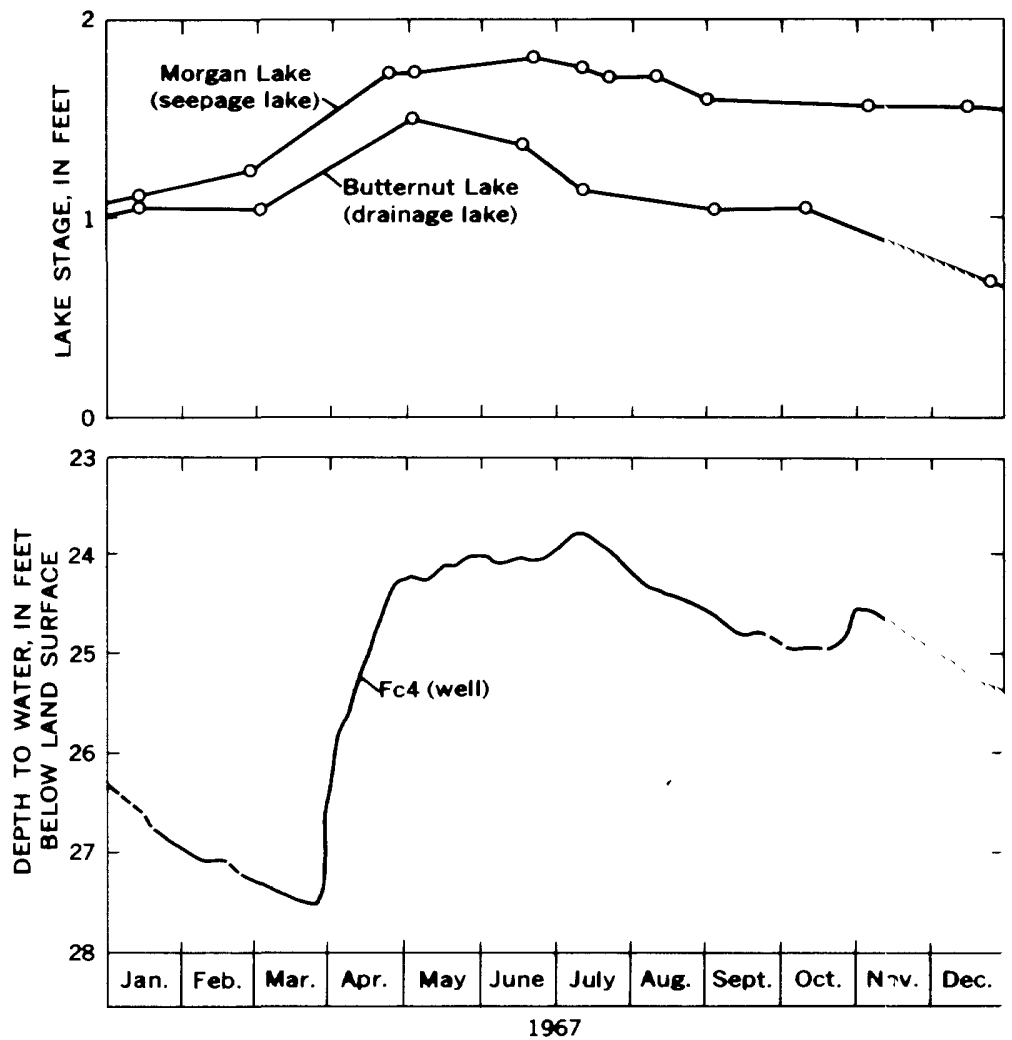

FIGURE 16.-Comparison of water-level fluctuations in a well, a drainage lake, and a seepage lake.

\section{NONWITHDRAWAL USE \\ NONRECREATIONAL USE}

Hydroelectric power generation is the major nonrecre tional use of water in the basin. The only power generating site is the Pine River powerplant, which can utilize as much as $624 \mathrm{cfs}$ of streamflow. Flow in excess of $624 \mathrm{cfs}$ is diverted through a spillway. For water year 1967 (a wet year) the powerplant used 73.1 percent of the flow of the Pine River. For the 1966 water year (a normal year) 91.6 persent of the flow was used. Even in a very dry year, the powerplant wo uld not use the entire flow of the river because some flow is continuous' $y$ released during shutdown periods (normally 8-12 hours overnight).

None of the settlements and small industries in the basin currently discharge sewage into the streams; if this is permitted in the future, stream quality will be degraded locally. 


\section{RECREATIONAL USE}

The major water-related recreational activities in the basin are canoeing, boating, camping, swimming, fishing, and hunting of waterfowl.

Canoeing is popular in the basin from spring ice breakup until the late autumn freeze. Plate 2 indentifies reaches of the river: that are used for general and white-water canoeing.

Developed sites for camping are shown on plate 2. Most of these are on lakes, although some public and privately-owned campsites are on the canoeable part of the Pine River. Along the canoeable parts of the rivers, primitive and potential campsites useful to canoeists are shown on plate 2 .

A total of 114 general canoeing miles exist in the Pine and Popple Rivers at normal stream stages, and of this total, 95 percent is usually without major obstructions such as large rapids and falls. General canoeing at normal stage is possible from the Pine River campground to the Menominee River, a distance of 72 miles. The North Branch Pine River is generally canoeable from a landing point at Forest Service Road 2174 to the confluence with the Pine River, $\approx$. distance of 7 miles. The Popple River is generally canoeable from State Highway 55 to its confluence with the Pine River, a distance of 35 miles. Usually none of the other tributaries to either the Pine or the Popple Rivers have enough water during most of the summer to be deep enough for canoeing. The Pine River below the Pine River powerplant dam is unpredictable for canoeing because the discharge is regulated. Beaver dams and logjams in the upper reaches of the strearn are seasonal variables which constitute local hazards to canoeing.

Major white-water falls and rapids include about 5 percent of the 114 stream miles that generally are canoeable during normal stages. In addition, there are other areas of minor rapids and swift vrater that are variable in extent, depending on stream stage. Major white-water canoeing areas, shown on plate 2, have distinctive scenic beauty. Falls and rapids are formed where erosion-resistant rock and channel constrictions result in steepened stream gradients and increased velocities.

Most major white-water areas in the basin are rated by the International Scale of River Difficulty (Peekna, 1967, p. 9-11) and are given in table 7 and plate 2 . Rapids in the basin are rated $I$ through IV during periods of medium to high flows.

Although some rapids and falls are generally canoeable at low water stage, they are noncanoeable at normal to above-normal stages. Some of these rapids and falls are given in table 7. On the P:ne River, LaSalle Falls is not canoeable at any time, and Snaketail Rapids, Pine Rapids, and Meyers Falls should be canoed only by experts. On the Popple River, Jennings Falls, Big. Bull Falls, and Little Prll Falls 
TABLE 7.-C'anoeability rating of selected rapids, falls, and braided sectiors of streams [If multiple ratings are given, the first rating is for the first rapids, the second rating is for the second rapids]

\begin{tabular}{|c|c|c|c|c|c|c|c|}
\hline \multirow[b]{2}{*}{ Feature } & \multirow[b]{2}{*}{ Location } & \multirow{2}{*}{$\begin{array}{l}\text { Length } \\
\text { (ft.) }\end{array}$} & \multirow{2}{*}{$\begin{array}{l}\text { Total } \\
\text { drop } \\
\text { (ft.) }\end{array}$} & \multirow[b]{2}{*}{ Rating } & \multicolumn{2}{|c|}{ Portage } & \multirow[b]{2}{*}{ Remarks } \\
\hline & & & & & Side & $\begin{array}{l}\text { Length } \\
\text { (ft.) }\end{array}$ & \\
\hline \multicolumn{8}{|c|}{ North Branch Pine River } \\
\hline Unnamed rapids. & $\begin{array}{l}\mathrm{T} 40, \mathrm{R}, 13, \\
\mathrm{SW}^{1 / 4}, \mathrm{SW}^{1 / 4} \\
\mathrm{~S} .14 . \\
\end{array}$ & 700 & & $\mathrm{I}$ & Left & $+\cdots \cdots \cdots$ & $\begin{array}{l}\text { Low stages require port- } \\
\text { ag because of rocky } \\
\text { and shallow conditions. }\end{array}$ \\
\hline \multicolumn{8}{|c|}{ Pine River } \\
\hline Wildcat Rapids. & & 800 & 5 & I & Lef $t$ & 400 & $\begin{array}{l}\text { Low stages require port- } \\
\text { age because of rocky } \\
\text { and shallow conditions. }\end{array}$ \\
\hline Unnamed rapids. & $\begin{array}{l}\text { T. } 40, \text { R. } 13 \text {, } \\
\text { center } \\
\text { S. } 36 .\end{array}$ & 300 & $1-2$ & 1 & $\ldots \ldots \ldots \ldots$ & . $\quad .$. & $\begin{array}{l}\text { Rapits in two pitches. } \\
\text { Medium to high stages } \\
\text { can be navigated with- } \\
\text { out touching rocks. }\end{array}$ \\
\hline $\begin{array}{l}\text { Conners Bridge } \\
\text { Rapids. }\end{array}$ & $\cdot$ & 300 & & I & $-\quad \cdots \cdots \cdots$ & $\cdots \cdots$ & $\begin{array}{l}\text { Very fast current. } \\
\text { Mid rapids. }\end{array}$ \\
\hline Unnaned rapids. & $\begin{array}{l}\text { T. } 39, \text { R. } 14 \text {, } \\
\text { top S. T. }\end{array}$ & 150 & . & I & $\cdot \quad \cdots \cdots \cdots$ & $\cdots$ & $\begin{array}{l}\text { Rapils in two pitches } \\
\text { with island between. }\end{array}$ \\
\hline $\begin{array}{l}\text { Anderson Bridge } \\
\text { Rapids. }\end{array}$ & $\cdots \cdots, \quad \cdots \cdots \cdot \cdot$ & 3,700 & $\cdots \cdots$ & I & $\cdots \quad \ldots \cdots \cdots$ & $\cdots \quad \cdots$ & $\begin{array}{l}\text { Rapits and rips in series } \\
\text { of pitches with swift } \\
\text { current. Easy rapids. }\end{array}$ \\
\hline Perenick Rapids. & \multirow{2}{*}{$\begin{array}{l}\text { T. } 39, \text { R. } 14 \\
\text { S. } 10,15\end{array}$} & 350 & .. & I & 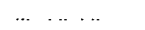 & ..... & Ersy rapids. \\
\hline $\begin{array}{l}\text { Unnamed Rapids } \\
\text { (below } \\
\text { Kingstone Creek). }\end{array}$ & & 1,000 & . & 11 & n............ & $+\cdots$ & $\begin{array}{l}\text { Rapids in series of } \\
\text { pitches. }\end{array}$ \\
\hline Unnamerl rapids. & $\begin{array}{l}\text { T. } 39, \text { R. } 14 \\
\text { NE1. S. } 11\end{array}$ & 150 & 2 & I. II & $\cdots+\cdots$ & . & Rapids in two pitches. \\
\hline $\begin{array}{l}\text { Stevens Creek } \\
\text { Rapids. }\end{array}$ & . $\quad \cdots$ & $\begin{array}{l}2,500 \\
3,000\end{array}$ & . & I, II & $\cdots \cdot \cdots$ & . & $\begin{array}{l}\text { Series of rapids with } \\
\text { fast current. }\end{array}$ \\
\hline Chipmunk Rapids. & $\cdots \ldots$. & 200 & 4 & I & . & $\cdots \quad-$. & $\begin{array}{l}\text { Stay left of center for } \\
\text { best results. Avoiding } \\
\text { all rocks takes expert } \\
\text { canoeing. }\end{array}$ \\
\hline Snaketail Rapids. & $\cdots$ & 600 & $\cdots \cdot$ & $\begin{array}{l}\text { 'Non- } \\
\text { canoeable }\end{array}$ & $\begin{array}{l}\text { Left-upper, } \\
\text { right-lower }\end{array}$ & $\begin{array}{l}300 \\
150\end{array}$ & $\begin{array}{l}\text { Rapids are in two pitches } \\
\text { separated by a } \\
\text { quiot poul. }\end{array}$ \\
\hline Meyers Falls. & $\cdot \quad .$. & $\cdots \cdots \cdots$ & 4 & $\begin{array}{l}\text { 'Non- } \\
\text { canoeable }\end{array}$ & Right & 300 & $\begin{array}{l}\text { Canoes should be landed } \\
300 \mathrm{ft} \text {. above falls } \\
\text { and lined down to it. }\end{array}$ \\
\hline $\begin{array}{l}\text { Bull Falls and } \\
\text { Rapids. }\end{array}$ & $\cdots \cdots \cdot \quad \cdots$ & 1,600 & $\cdots .$. & I & Left & 1,600 & $\begin{array}{l}\text { Nornal stages can be } \\
\text { canoed but is very } \\
\text { roc'y. }\end{array}$ \\
\hline Unnamed rapids. & $\begin{array}{l}\text { T. } 39, R, 17, \\
\text { NW } 1 / 4, \text { NW } 1 / 4 \text {, } \\
\text { S. } 4 .\end{array}$ & $<100$ & $\cdots$ & I & $\cdots \quad \cdots$ &... & $\begin{array}{l}\text { Very mild rapids- } \\
\text { slightly rocky and } \\
\text { shallow. }\end{array}$ \\
\hline Braided area. & $\begin{array}{l}\text { Below Sealion } \\
\text { Lake. }\end{array}$ & 1.600 & $\ldots \ldots$ & & & & $\begin{array}{l}\text { Keep right through this } \\
\text { area. Certain islands } \\
\text { potential wilderness } \\
\text { camp sites. }\end{array}$ \\
\hline LaSalle Falls. & . & $\cdots \cdots$ & 20 & $\begin{array}{l}\text { 'Non- } \\
\text { canoeable }\end{array}$ & Left & 1,300 & $\begin{array}{l}\text { Canveing should not be } \\
\text { attempted at any time. } \\
\text { Lorger portage on right } \\
\text { banks with better view. }\end{array}$ \\
\hline Pine Rapids. & .. & 1,300 & $\cdots .$. & $\begin{array}{l}\text { 'Non- } \\
\text { canoeable }\end{array}$ & Lef $\mathrm{t}$ & 1,300 & $\begin{array}{l}\text { Very short rating I } \\
\text { rapids about } 1 \text { mile } \\
\text { belcw LaSalle Falls. }\end{array}$ \\
\hline $\begin{array}{l}\text { Pine River } \\
\text { hydroplant. }\end{array}$ & $\cdots \cdots \cdot$ & $\ldots \ldots \ldots$ & 100 & $\cdot \quad . . \quad \ldots \ldots$ & $\begin{array}{l}\text { Between } \\
\text { raceway } \\
\text { and spill- } \\
\text { way of dam }\end{array}$ & 2,100 & Portaze on dirt road. \\
\hline $\begin{array}{l}\text { Pine River hydro- } \\
\text { plant to mouth. }\end{array}$ & $\cdots$ & . & $\cdots$ & .... & $\cdot \quad \cdots \quad \cdots$ & $\cdots$ & $\begin{array}{c}\text { Intermittent regulation } \\
\text { by hydroplant renders } \\
\text { this reach unpredict- } \\
\text { able canoeing water. }\end{array}$ \\
\hline & & & Por & ple River? & & & \\
\hline Unnamed rapids. & $\begin{array}{l}\text { T. } 38, \text { R. 14, } \\
\text { NE, } 1 / 4 . \text { NE } 1 / 4 . \\
\text { S. } 9 .\end{array}$ & 600 & $\ldots$ & I. II & $\begin{array}{l}\text { Left-first, } \\
\text { right- } \\
\text { second and } \\
\text { third }\end{array}$ & 600 & $\begin{array}{l}\text { Rapids in three pitches: } \\
\text { first mild, second } \\
\text { severe, third dangerous. }\end{array}$ \\
\hline
\end{tabular}


TABLE 7.-C'anoeability rating of selected rapids, falls, and braided sections of streams-Con.

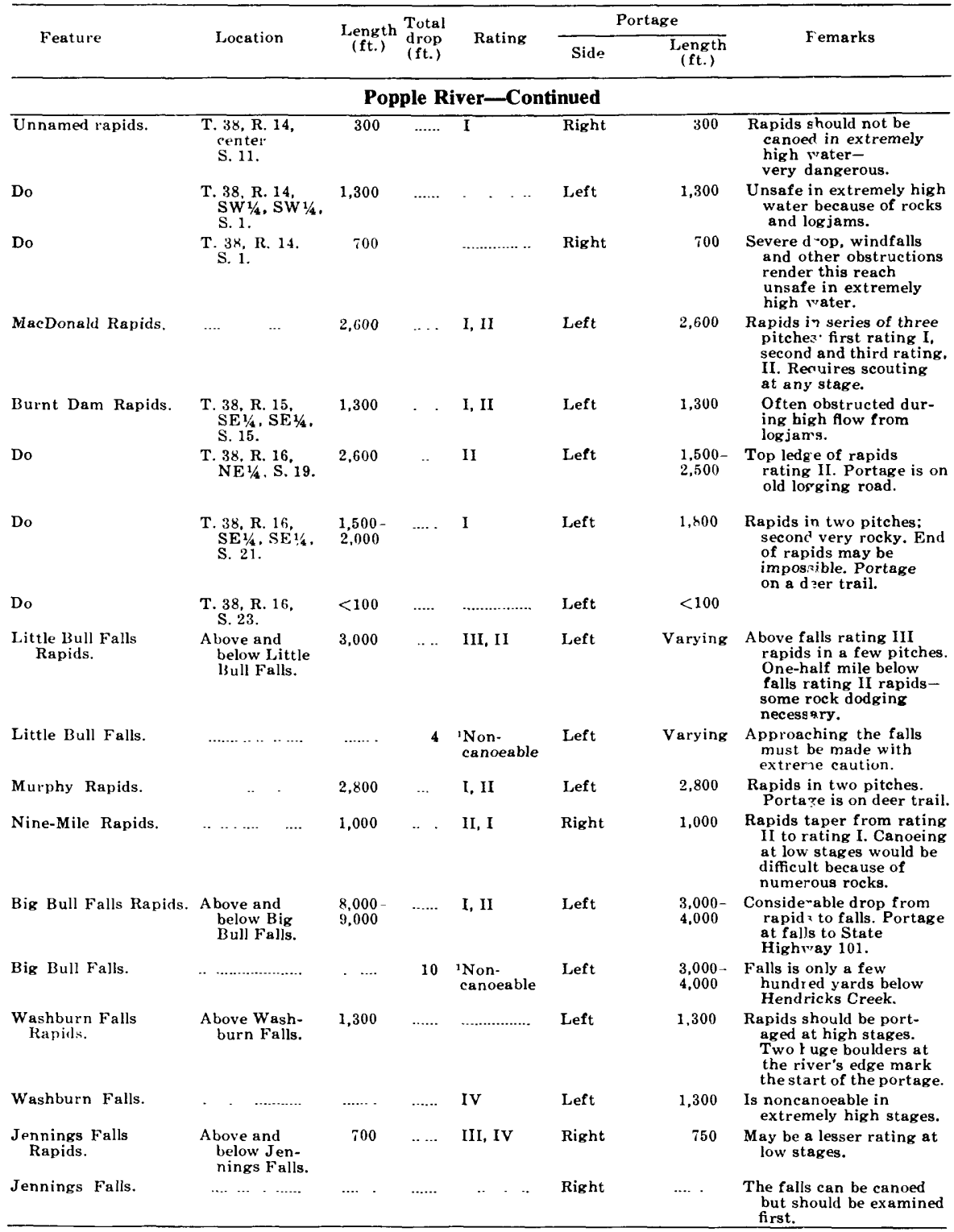

'At stages less than medium to high, this rating will be IV.

"The Popple River was canoed at an extremely high stage. Portage distances will undoubtedly be lers at lower stages. 
also should be canoed only by experts. Other reaches of the rivers may be very difficult or noncanoeable for varying periods of time and for reasons ranging from nonnavigable low water to safety hazards at high stages (see table 7). The current use of streams for canoeing on an average weekend day is small-estimated to be less than one canoeist per mile of stream per day. The streams could support $\varepsilon$ severalfold increase in canoeing and still maintain their wild river character (Wisconsin Department of Natural Resources, 1968, p. AF-378).

Boating on lakes in the basin is primarily for fishing and pleasure. Boating activity is estimated to be less than one boat per 15 acres of water per day, an estimate based on current demand and planning criteria for northeastern Wisconsin (Wisconsin Department of Natural Resources, 1968, p. F-187). Lakes and public access points are shown on plate 2 and given in table 2. Large lakes with commercial facilities or summer homes around them (such as Long Lake, Stevens Lake, and Butternut Lake) are used by people in powerboats and on waterskis.

The hunting of waterfowl and trapping of small mammals is a minor activity related to water in the basin. Waterfowl hunting is a seasonal, relatively small use restricted to headwaters wetlands and to small pothole lakes. Trapping is also seasonal and is generally along streambanks and around small lakes.

Swimming is a small summer use of water in the basin and is generally restricted to developed beaches on large lakes. How?ver, many small lakes are also used for swimming. Good swimming lakes with clear water and sandy shores are Franklin Lake in Forest County, Morgan Lake in Florence County, and Hilbert Lake in Marinette County.

Fishing in streams and lakes in the basin is an important recreational use of water. Stream fishing in the basin is for brook, brown, and rainbow trout. However, stream fishing density is low, only about one fisherman per mile of stream (Mason, 1968). Lake fishing is less than the planning criterion of one fisherman per 3.6 acres of lake per day (Wisconsin Department of Natural Resources, 1968, p. F-183).

Lake fishing is primarily for panfish, northern pike, and yellow walleye. The greatest lake fishing pressure is on the large developed lakes such as Butternut Lake, Long Lake, Stevens Lake, Emily Lake, Keyes Lake, Halsy Lake, and Fay Lake.

\section{RELATION OF WATER TO PLANTS AND ANIMALS}

Seasonal and long-term variations in the flow of streams, stage of lakes, depth to ground water, and quality of water influen?e the pattern of ecologic development. The rivers, lakes, wetlands, forests, and moraine hills each have distinctive plant and animal associa tions. 
During long drought periods when lake levels decline, wetlands dry out and streamflow diminishes; plants most sensitive to water-level changes may die, and fish in streams may migrate to strean reaches that have desirable (cool) temperatures and gradients. Aninal populations in the basin are not affected by hydrologic changes to any great extent because of their mobility.

During periods of flooding, sediments and nutrients temporarily alter the characteristics of streams and lakes. During period's of high ground-water levels, vegetation intolerant to saturated root systems may die.

\section{FORESTS}

Forests are important to the hydrologic cycle of the Piro-Popple River basin. Most of the basin is covered by forests or wetlands, and less than 10 percent is cleared land. Forests retain snow on the ground; the resultant extension of the melting period permits ground-water recharge, lessens direct runoff, and minimizes floods. Erosion is minor in forested areas except for new roadcuts and rutted trails. Forests are the major water users in the basin and are responsible $\mathrm{fc}^{*}$ most of the 19 inches of annual evapotranspiration.

Tree growth in the basin is closely related to the depth to ground water, ground-water quality, and fluctuations of the. water table (Wilde and Zicker, 1948). A generalized grouping of current forestcover types and their relation to ground water in the basin $\varepsilon$ re shown on plate 2. There are four main categories: wetlands, containing swamp conifers and bottom-land hardwoods; till uplands, containing northern hardwoods and conifers; sandy uplands, containing pines; and till and outwash uplands containing aspen stand's (pl. 2).

In wetlands the water table is at or within a foot of the surface, and it fluctuates less than 1 foot annually. However, during abnormally wet periods, the water table can rise several feet, flooding surrounding land and killing trees. Beaver dams in the headwaters area of the Pine River have locally raised stream and ground-water stages by several feet and killed wetland forest species. Droughts lower water levels and retard the growth of wetland trees.

In upland areas, where loamy soils developed on till rave high moisture-retention capacities, the water table is generally nore than 3 feet below the land surface. Northern hardwoods and conifers grow well in upland areas and are not affected by changes in ground-water levels or short droughts.

In upland areas where soils developed on outwash sand, soil-moisture retention is too low to support northern hardwoods anc conifers. In these areas, where the water table is generally more than 3 feet below land surface, pines are the forest-cover type. Changes in groundwater levels of several feet have little effect on pines; how'ever, the 
rate of growth of jack pine having roots near the water table may be affected. Jack pines are usually found in the driest sandy areas in the basin. Even though white pines achieve their maximum growth where the water table is $3-4$ feet below the land surface, these trees can survive through a wide range of depths to the water table. Red pines differ from white pines in that they grow well in dry areas.

Aspen grow in a variety of soils and in areas where the depth to the water table ranges from less than 1 foot to more than 8 feet. Aspen grow best where the water table is 2-3 feet below land surface (Wilde and Pronin, 1949), or on upland till or outwash where the water table is deep and soil-moisture retention is high.

\section{AQUATIC VEGETATION}

Aquatic vegetation, which grows in most reaches of the streams, locally retards the flow of water, supplies dissolved oxygen during daylight hours, reduces the nutrient content of the water, and supports fish life. Aquatic plants commonly cover 5-10 percent of the stream bottom areas but may cover nearly 100 percent according to Galen Smith (written commun., 1969).

relative abundance of individual species and in the total number of species present. The greatest number of species are found in the South Branch Popple River and in the headwaters of the Popple River main stem. The greatest abundance of individual snecimens of the same species is found in the midreaches of the Pine River. In general, aquatic plant abundance and diversity are greatest in shallow water with slow velocity.

Some stream reaches are barren of aquatic vegetation. Rapids are generally barren. The dense leaf canopy covering Woods C'eek, which is remarkably barren of plants, suggests that shade inhibits aquatic plant growth. The Pine River below site A (fig. 3) has little aquatic vegetation for about 3 miles below the powerplant, probably because the river stage fluctuates widely. Farther downstream the vegetation increases in quantity and species diversity. At the mouth of the Pine River and upstream for about one-quarter mile, species are found that are rare or absent in the rest of the stream, reflecting the nutrient quality of water backed up from the Menominee River.

A few streams, especially the one connecting Long Lake and Fay Lake, contain very luxuriant species typical of eutrophic lakes in Wisconsin. This condition may reflect the influence of lakeshore development on water quality.

The flora of natural lakes and large artificial impoundments is generally different from that of streams. Lake vegetation ranges from flora typical of eutrophic lakes (for example, Fay Lake) to flora typical of oligotrophic lakes (for example, Morgan Lake). 


\section{FISH AND WILDLIFE}

Streamflow, water quality, and water temperature are factors that determine the types and number of fish in reaches of streams and in lakes within the basin. In general, streems support cold-water fish and lakes wupport warm-water fish (Hubbs and Lagler, 1958, p. 4).

found in most streams. Trout prefer the coldest parts of the Pine and Popple Rivers and tributary streams, particularly in the Pine River from Chipmunk Rapids to the powerplant flowage, and in the Popple River from the confluence with the South Branch Popple River to the Pine River. Trout are also found in warm, slow-moving headwater streams that also support complexes of warm-water fish and in cool, fast-moving parts of streams that support complexes of coldwater fish.

Dissolved oxygen in streams of the basin is generally in excess of $6.5 \mathrm{mg} / \mathrm{l}$, which is adequate for trout. Trout require at least $6 \mathrm{mg} / \mathrm{l}$ DO, although they can survive for short periods at $5 \mathrm{mg} / \mathrm{l} \mathrm{L}$.

Trout require water temperatures that usually do not excsed $24^{\circ} \mathrm{C}$ $\left(75^{\circ} \mathrm{F}\right)$. Of the 14 sites on the Pine and Popple Rivers where stream temperatures were monitored during the 1967 water year, six sites had maximum temperatures above $24^{\circ} \mathrm{C}$. These sites were in the flat headwater areas of both rivers and in wide, sluggish, poorly shaded areas. The remainder of the sites compared favorably with the $23^{\circ} \mathrm{C}$ $\left(74^{\circ} \mathrm{F}\right)$ maximum at site $\mathrm{C}$. However, the maximum recorc ${ }^{\prime} \cdot \mathrm{d}$ water temperature at site $\mathrm{C}$ from October 1964 to May 1968 vas $28^{\circ} \mathrm{C}$ $\left(83^{\circ} \mathrm{F}\right)$.

Brook trout is the only trout indigenous to the basin, and also the only trout capable of maintaining adequate population levels by natural reproduction. However, brook trout die if exposed to stream temperatures of $24^{\circ} \mathrm{C}$ for more than a few hours (Brasch ard others, 1962, p. 4). When stream temperatures in the Pine and Popple Rivers reach intolerable limits, the brook trout migrate into the cocler tributary streams (Mason, 1968), such as Woods Creek, Coc'y Creek, Lepage Creek, Lamon Tangue Creek, Hendricks Creek, Johnson Creek, and the Little Popple River in Forest County.

Brown trout, introduced into the basin, can tolerate warmer water than brook trout. The optimum temperature range for brown trout is from $18^{\circ}$ to $24^{\circ} \mathrm{C}\left(65-75^{\circ} \mathrm{F}\right)$, although temperatures as high as $27^{\circ} \mathrm{C}\left(81^{\circ} \mathrm{F}\right)$ can be tolerated for short periods (Brynildson and others, 1964, p. 4). Because brown trout do not reproduce in significant numbers in the basin, they require stocking to maintain adequate population levels. Brown trout spawn in main stem rapids where anchor ice accumulations may destroy the eggs during the overwinter incubation period (Mason, 1968). 
Rainbow trout, also introduced, do not reproduce in this basin; therefore they do not carry over from one year to the nert. They are not compatible with the stream conditions of the basin (Mason, 1968, p. 4).

In general, warm-water fish thrive in the lakes of the Pine-Popple River basin, and their distribution is determined by water quality, water temperature, lake depth, and bottom conditions. Game-fish types found in the basin are given in table 2. Trout are rot common in lakes within the basin.

The basin has an abundant supply of wildlife. Deer, b?ar, coyote, squirrel, woodcock, and ruffed grouse are common thrcughout the basin, and beaver, muskrat, and waterfowl inhabit the wetland areas. Of these, the beavers have the most influence on local hydrology because their dams impound stream water.

\section{MANAGEMENT CONSIDERATIONS}

The Pine and Popple Rivers have been designated wild rivers by Chapter 363 of the State of Wisconsin Laws of 1965 (see section on "Wisconsin Wild Rivers Bill"). The law states that these rivers should "receive special management to assure their preservation, protection, and enhancement of their natural beauty, unique recreational and other inherent values***." Thus management should consider preserving the entire Pine-Popple River basin because any significant changes within the basin may affect the stream regimen.

At the present time, man's effects on the basin are minor, and no significant water problems exist. Because of the wild-river designation of the Pine and Popple Rivers and because of the basin's crol climate, steep topography, large areas of public lands, and wild nature, it is likely that future development will be confined largely tc recreation within the area above the Pine River powerplant. Most of the development below the powerplant will not affect the wild-river part of the basin.

Because fishing, especially for trout, is a popular recreat'onal activity in the basin, land and water managers should consider practices that do not adversely affect the water temperature and quality requirements for fish survival.

Lake eutrophication, a natural process of lake enrichment, presently is not a significant problem in the basin. However, large concentrations of cottages surrounding lakes, with attendant road construction, septic-tank effluent, and trash dumps, may accelerate the rate of eutrophication. This problem may be controlled by limiting lot size and, therefore, the number of cabins; by taking ordinary precautions to control erosion during road and cottage constrution; and by assuring proper septic-tank construction. At the present time only 
Fay Lake (which is surrounded by cottages) displays chararteristics of a eutrophic lake (Galen Smith, written commun., 1968).

Small-scale pumpage of ground or surface water for domestic or stock needs anywhere in the basin will have little or no effest on the hydrologic regimen.

Large-scale pumpage of ground or surface water may affect the hydrologic regimen by diminishing or thermally altering streamflow.

The injudicious application of herbicides, pesticides, and fertilizers may be detrimental to the biologic regimen of surrounding lakes and streams. Herbicides used for brush control along roads and for understory forest management and pesticides used around cottages may be washed into surface water, where they can kill fish and destroy desirable aquatic plants. Overapplication of fertilizers containing nitrogen locally increases nitrate concentrations in ground water and accelerates the eutrophic process in lakes and streams.

Canoeing use of the Pine and Popple Rivers can increase considerably without affecting the wild nature of the streams. Maximum compatibility among surface-water users may be achieved if waterskiing and powerboating are restricted to large lakes.

Certain aspects of the land and water resources of the basin could be developed without affecting most of the wild nature of the area. The eastern one-third of the basin is largely owned privately, but use is limited to scattered homes and small farms. Because the regional movement of ground water, as well as surface-water flow, is toward the east, water use in this area should have little effect upon the western two-thirds of the basin. The river below the Pine River powerplant is most suitable for development, and any changes in this reach would not affect the attractiveness or water quality of the river upstream.

The western two-thirds of the basin is largely in the Nicolet National Forest, which is managed under a multiple-use plan. Under a continuation of the plan, the Federally owned land would stay essentially wild and yet could still provide harvestable timber and managed land and water recreational sites.

State- and county-owned lands are managed under devilopment plans compatible with the maintenance of a wild area. In addition, the State has leases and agreements with private owners ccncerning the planned development of lakeshores and streambanks. About 70 percent of the streambanks of the canoeable parts of the Pine and Popple Rivers is protected under Federal, State, county. or private agreements.

In the absence of agreements, unrestricted use of privately owned riparian land may be detrimental to the maintenance of a wild river area. Campground and residential developments currently are small 
and have little effect on the hydrologic system. Any expanded development should be planned to have a minimal effect on the ecologic system and to assure that the wild nature of the area is maintained. Where ground water moves through a lake, development on the side of the lake that is losing water to the aquifer would lessen the effects of waste disposal on the lake. In this manner any pollutants entering the ground would move away from rather than towards the lake. Zoning shorelands on navigable water in the basin (Wisconsin Statute 30.26 ) should prevent overdevelopment and should help to maintain the natural beauty of the area.

Careful consideration should be given to streambank clearing, dam building, and other activities that raise stream temperatures or otherwise alter stream character. High temperatures with reduced DO concentrations make streams unsuitable as trout habitats. Large-scale drainage of wetlands is detrimental to the wild aspect of $t r o$ basin and locally changes the hydrologic regimen. Small-scale drainage of wetlands for building or other purposes probably has little detrimental effect on the hydrologic regimen.

\section{SUMMARY AND CONCLUSIONS}

The Pine-Popple River basin is one of the few remainirg relatively wild areas in Wisconsin. To encourage the preservation of its unique characteristics, the Pine and Popple Rivers have been designated "wild rivers" by legislative action. Because the rivers are part of a basinwide hydrologic system, any water-related natural-resource planning or development should consider the possible effects on the entire basin.

Water of good quality occurs in the Pine and Popple Rivers and their tributaries, in more than 70 lakes, and in saturatec unconsolidated glacial deposits. Precipitation, averaging about 30 inches per year, is largely (19 inches) returned to the atmosphere by evapotranspiration, and only 11 inches leaves the basin as streamflow. Streamflow is highest in spring and early summer and lowest between mid-July and mid-September, when evapotranspiration is highest. The average flow of the Pine River at the Pine River powerplant is about $420 \mathrm{cfs}$; a maximum flow of $4,380 \mathrm{cfs}$ has been recor led. Flooding is not a problem in the basin. The lakes of the basin ar? randomly distributed and can be classified as either seepage (with no surface outlet) or drainage (with surface outlet). Streamflow thrcughout the basin is augmented from ground-water discharge at an average rate of 2-3 cfs per mile of stream.

Ground water from glacial drift overlying Precambrian bedrock supplies the base runoff of streams and is the source of water for domestic and other uses. The water table generally is within about 
1 foot of the land surface in the extensive wetlands, especially in the southern and southwestern parts of the basin; it may be as deep as 150 feet below land surface in some highland areas. Grourd-water movement in the basin is predominantly from west to east, following the direction of the regional slope of the topography and of the bedrock surface. Locally ground water moves toward and discharges to streams. In seepage lakes and in many drainage lakes, ground water moves into the lakes from one side and reenters the ground-water reservoir on the opposite side. Ground-water supplies adequate for domestic use can be obtained from wells throughout the basin; up to $500 \mathrm{gpm}$ of ground water can be obtained locally where the saturated sand and gravel is over 50 feet thick.

Surface and ground water are of similar quality. The water, a hard bicarbonate type low in dissolved solids, ranges from slight'y acidic to slightly basic. Although both ground water and surface water are locally high in iron, the water is usable for most purposes. Many streams, especially those associated with wetlands, have colored water, but generally the sediment load of streams througl out the basin is very small. Dissolved oxygen, high in streams and mc st lakes, seldom becomes critical for fish populations.

Water use in the basin is largely of the nonwithdrawal type, which includes hydroelectric power generation, fishing, swimming, canoeing, and other recreational activities. Most of the flow of the Pine River is used for power generation. Canoeing is confined largely to the main stems of the Pine and Popple Rivers. Ninety-five percent of the 114 canoeable stream miles are without major obstructions, and about 5 percent consists of white-water falls and rapids. Water withdrawn from wells, about $200,000 \mathrm{gpd}$, is largely for domestic use. This $200,000 \mathrm{gpd}$ is equal to only about 0.7 percent of the average flow of the Pine River. Water is not withdrawn from lakes or streams, and streams are not used to transport sewage.

A close relationship exists between the plants, animals, and water of the basin. The distribution of forest-cover types is dependent, in part, on soil type and ground-water levels. Abnormal fluctuations in the water table may kill trees locally. Forests help retain snow on the ground, which extends melting periods and minimizes floods. Trees and other plants utilize most of the 19 inches of annual evapotranspiration. Aquatic vegetation grows in most lakes and streams, except in shaded areas and reaches of high velocity or with extreme fluctuation of stage. The type and distribution of fish in lakes and streams is determined by streamflow, water quality, and water temperature. In general, streams support cold-water fish and lakes support warmwater fish. Brook, brown, and rainbow trout are the major stream and game fish in the basin, although only brook trout are native to 
the area.

At the present time, man's effects on the basin are minor, and no significant water problems exist.

Because of the wild-river designation of the basin anc because of the cool climate, steep topography, and the large undeve'oped areas of public and private land, it is likely that future development will be largely recreational in the area above the Pine River powerplant. Extensive water and land use in the area east of the Pine Fiver powerplant should have a negligible effect upon the wild-river part of the basin. The area below the Pine River powerplant is suitable for development because changes there would not affect the attractiveness of the area or the quality of the water upstream. Because the western two-thirds of the basin is largely within the Nicolet National Forest, it should stay essentially wild even though its timber is harvested and its water recreational sites are used.

\section{SELECTED REFERENCES}

Bayley, R. W., Dutton, C. E., and Lamey, C. A., 1966, Geology of the Menominee iron-bearing district, Dickinson County, Michigan and Florence and Marinette Counties, Wisconsin: U.S. Geol. Survey Prof. Paper 513, 96 p.

Brasch, John, McFadden, James, and Kmiotek, Stanley, 1962, The eastern brook trout, its life history, ecology and management: Wisconsin Conserv. Dept. Pub. 226, 11 p.

Brynildson, O. M., Hacker, V. A., and Klick, T. A., 1964, Brown trout, its life history, ecology and management: Wisconsin Conserv. Dept. Pub. 234, 14 p.

Devaul, R. W., 1967, Trends in ground-water levels in Wisconsin through 1966: Univ. Ext., Univ. Wisconsin Geol. and Nat. History Survey Inf. Circ. 9, 109 p.

Dutton, C. E., and Linebaugh, R. E., 1967, Map showing Precambrian geology of the Menominee iron-bearing district and vicinity Michigan and Wisconsin: U.S. Geol. Survey Misc. Geol. Inv. Map I-466.

Dutton, C. E., and Bradley, R. E., 1970, Lithologic, geophysical, and mineral maps, Precambrian rocks, Wisconsin: U.S. Geol. Survey Misc. Geol. Inv. Map I-631.

Hindall, S. M., and Flint, R. F., 1970, Sediment yields of Wisconsin streams: U.S. Geol. Survey Hydrol. Inv. Atlas HA-376.

Hole, F. D., Olson, G. W., Schmude, K. O., and Milfred, C. J., 1962, Soil survey of Florence County Wisconsin: Wisconsin Geol. and Nat. Hirtory Survey Bull. 84, $140 \mathrm{p}$.

Hole, F. D., Beatty, M. T., Milfred, C. J., Lee, G. B., and Klingelhoets, A. J., 1968, Soils of Wisconsin: Univ. Ext., Univ. Wisconsin Geol. and Nat. History Survey map.

Horton, R. E., 1945, Erosional development of streams and their drainage basins, hydrophysical approach to quantitative morphology: Geol. Soc. America Bull., v. 56, p. 275-370.

Hough, J. L., 1958, Geology of the Great Lakes: Urbana, Illinois Univ. Press, $313 \mathrm{p}$.

Hubbs, C. L., and Lagler, K. F., 1958, Fishes of the Great Lakes re ̧̧ion: Bloomfield Hills, Mich., Cranbrook Inst. Sci. Bull. 26, 135 p.

Mason, Jack, 1968, Management of the trout fishery in the Pine and Popple Rivers, Florence-Forest Counties: Wisconsin Dept. Nat. Resources, Water 
Resources Research Sec. rept., 7 p.

Peekna, Andres, 1967, Guide to white water in the Wisconsin area [4th ed.]: Wisconsin Univ. Hoofers Outing Club, 45 p.

U.S. Geological Survey, 1968, Water resources data for Wisconsin, 1967, Water Resources Div., 221 p.

Weidman, Samuel, and Schultz, A. R., 1915, The underground and surface water supplies of Wisconsin: Wisconsin Geol. and Nat. History Survey Bull. 35, 664 p.

Wilde, S. A., and Pronin, D. T., 1949, Relation of the rate of growth of quaking aspen to the depth of the ground water table and the content of soi organic matter in central Wisconsin: Wisconsin Conserv. Dept. Tech. Not? 33, $4 \mathrm{p}$.

Wilde, S. A., and Zicker, E. L., 1948, Influence of the ground water table upon the distribution and growth of aspen and jack pine in central Wisconsin: Wisconsin Conserv. Dept. Tech. Note 30, 12 p.

Wisconsin Conservation Department, 1955, Forest resources of Forest County: Wisconsin Forest Inv. Pub. 12, 23 p.

1957a, Forest resources of Florence County: Wisconsin Forest Inv. Pub. 28, 22 p.

1957b, Forest resources of Marinette County: Wisconsin Forest Inv. Pub. 29, 22 p.

1961, Beaver-trout-forest relationships: Wisconsin Conserv. Dent., 34 p. 1964, Wisconsin lakes: Wisconsin Conserv. Dept. Pub. 218-64, 67 p.

Wisconsin Department of Natural Resources, 1968, Wisconsin's outdoo recreation plan: Wisconsin Dept. Nat. Resources Pub. 802, 397 p.

Wisconsin Legislature, 1965, Assembly Bill 673 in Water resources act, Chapter 363, Laws of 1965: Madison, Wis., Dept. of Resource Devel., 26 p.

Young, K. B., 1965, Supplement to report on flow characteristics of $\mathrm{W}^{\top}$ isconsin streams: U.S. Geol. Survey open-file report, $81 \mathrm{p}$. 


\title{
WISCONSIN WILD RIVERS BILL
}

\section{STATE OF WISCONSIN}

Assembly Bill 673

\author{
Chapter 363, Laws of 1965
}

An Act to create 30.26 of the statutes, relating to designating the Pine, Pike and Popple rivers as wild rivers.

The people of the state of Wisconsin, represented ir senate and assembly, do enact as follows:

Section 1.30 .26 of the statutes is created to read:

30.26 Wild Rivers. (1) Legislative Intent. In order to afford the people of this state an opportunity to enjoy natural streams, to attract out-of-state visitors and assure the well-being of our tourist industry, it is in the interest of this state to preserve some rivers in a free flowing condition and to protect them from development; and for this purpose a system of wild rivers is established, but no river shall be designated as wild without legislative act.

(2) The Pike river in Marinette county, and the P'ne river and its tributary Popple river in Florence and Forest counties are designated as wild rivers and shall receive special management to assure their preservation, protection and enhancement of their natural beauty, unique recreational and other inherent values in accordance with guidelines outlined in this section.

(3) The conservation commission in connection with wild rivers shall:

(a) Provide active leadership in the development of a practical management policy.

(b) Consult other state agencies and planning committees.

(c) Collaborate with county and town boards and local development committees or boards in producing a mutually acceptable program for the preservation, protection and enhancement of the rivers.

(d) Administer the management program.

(e) Seek the co-operation of the U.S. forest service, timber companies, county foresters and private landowners in implementing land use practices to accomplish the objectives of the management policy.

(f) Act as co-ordinator under this subsection.

Section 2. This bill is declared to be an emergency bill, recommended by the joint committee on finance, in accordance with the requirements of section 16.47 (2) of the statutes. 


\section{INDEX}

[Italic page numbers indicate major references]

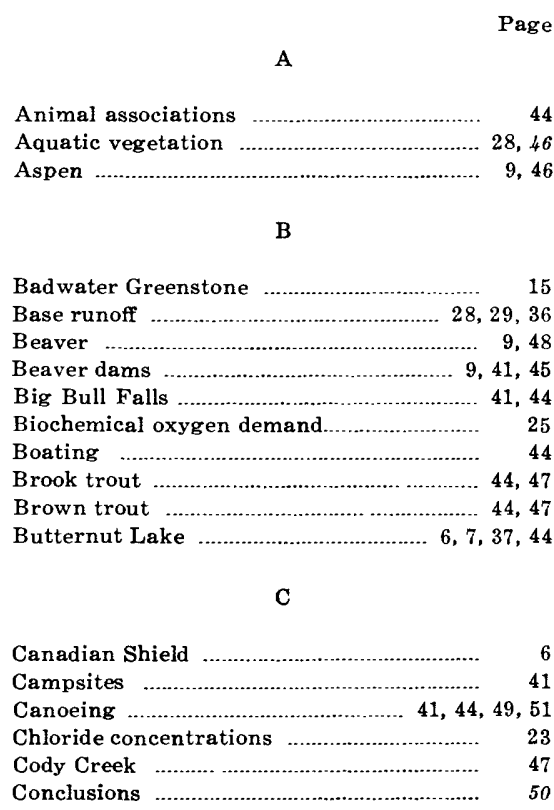

D

Discharge

$16,33,37$

monthly mean

16,19

Dissolved oxygen

$25,28,47,51$

Drainage lakes 23,37

Droughts

Duration curves, streamflow

$\mathbf{E}$

Emily Lake 33,44

Eutrophic lakes

9,46

Eutrophication, lake

Evapotranspiration $9,10,45,50$

F

Falls and rapids

41

Fay Lake $9,44,46,49$

Fertilizers

Fish

$44,48,51$

Fishing $18,45,50$

Floods

Florence-Common wealth iron mining district
Flow-duration curve

Forest fires

Forests

Franklin Lake

Glacial deposits

Goodman, Stambaugh soil association 8

Gradient profiles …................................ 15

Ground water .................................... 9, 10,50

accretion ….................................... 21

availability ....................................... 12, 51

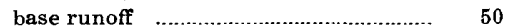

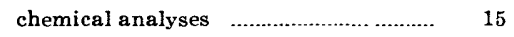

deposits ............................................ 11

discharge ......................................... 50

gradients .......................................... 11

hardness ..................................................... 12

movement ..................................... 11, 37, 51

occurrence …........................................ 11

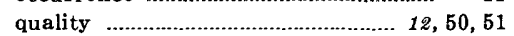

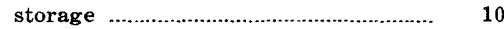

temperature

Ground water-surface water relationships ........................ 28, 51

H

Halsy Lake ................................................ 44

Hardness ......................................... 12, 23, 51

Hendricks Creek ....................................... 47

Herbicides ................................................. 49

Hilbert Lake ................................................. 44

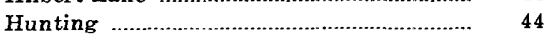

Hydroelectric power .................................... 40

Hydrologic cycle $\ldots \ldots \ldots \ldots \ldots \ldots \ldots \ldots \ldots \ldots . . . \ldots, 45,49$

Hydrology ..............................................

\section{I}

Ice ........................................................ 16

Infiltration rates, soils ................................ 8

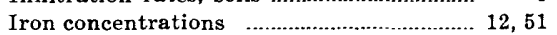

\section{$\mathbf{J}, \mathbf{K}$}

Jack pines

Jennings Falls .................................... 41, 44

Johnson Creek …........................................... 47

Keyes Lake ............................................. 33, 44

L

15 La Salle Falls ...................................... 41, 44

18

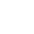




Lakes ..........
fishing
stages
Lamon Tangue Creek
Lauterman Creek
Lepage Creek
Little Bull Falls
Logging Popple River
Long Lake ...

M

Manganese concentrations

Menominee River

Meyers Falls

Michigamme Slate

Morgan Creek

Morgan Lake

Muck soils

\section{Page}

$9,23,37$

44,48

37

21,47

21

12

41,44

7

21

$9,37,44,46$

\section{$\mathrm{N}, \mathrm{O}$}

Nicolet National Forest

$9,49,52$

Nitrate concentrations

15,23

Northern pike

Oligotrophic lakes

9,46

\section{$\mathbf{P}$}

Panfish

Peat deposits

Pence-Iron River soil association

Pesticides

$\mathrm{pH}$

Phosphate concentrations

Pine Rapids

Pine River, aquatic flora

campsites

canoeing miles

development

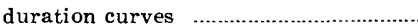

glacial déposits

gradient

gradient profile …...............................

North Branch …................... 15, 33,

powerplant

reservoir

18,40

power

runoff ................................................ 18

specific conductance …......................... 25

streamflow .................... 16, 18,40,50,51

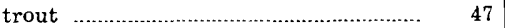

Pine-Popple River basin, aquatic

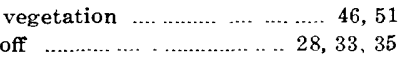

base runoff

bedrock

canoeing

$41,44,49,51$

development

$48,49,50,52$

drainage

3,8

duration curves $\ldots . . . . . . . . . . . . . . . . . . . . \ldots \ldots \ldots . . . . . \quad 33$

extent

$47,48,51$

fish

45,51

forests

geologic setting
Pine-Popple River basin-Continued ground water

lakes

$11,33,37$

location ..................................... 8

low flow ................................................. 20

management ........... 48

physical framework

precipitation …................................ 9,50

sediment yield .............................. 25

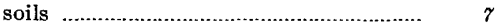

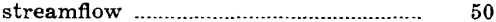

surface water ......................................... 15

surficial deposits ...................................

temperature …............................. 12, 27, 47

topography ...................................... 3,8

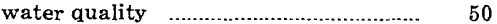

water table ............................................. 11

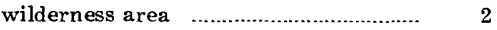

wildlife ........ 48

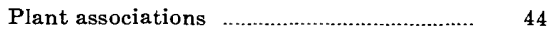

Popple River, aquatic flora ......................... 46

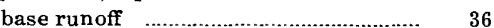

canoeing miles ....................................... 41

discharge .................................... 27

dissolved oxygen ...................................... 28

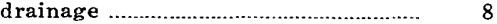

duration curves ...................................... 33

glacial deposits ...................................... 7

gradient ............................... 3,4

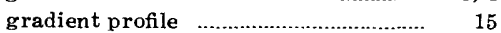

ground-water accretion ….................... 21

main stem ......... 16, 46

sediment yield ….............................. 8, 85

South Branch …............... 16, 33, 35, 36, 46

specific conductance ............................. 25

temperature …................................. 27, 47

trout ................................... 47

Precipitation …................................. 9, 10,50

Pumpage ….................................... 49

Purpose of study ...................................... 2

$\mathbf{R}$

Rainbow trout …................................... 44, 48

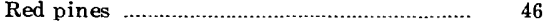

Reforestation …............................................ 9

Riley Creek ................................................. 21

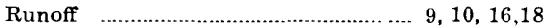

$\mathbf{S}$

Saline water …........................................... 15

Seepage lakes ….................................. 23, 37

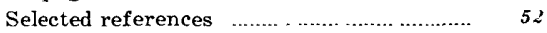

Simpson Creek ............................................

Simpson Creek basin ............................... 36

Smith, Galen, cited .............................. 46, 49

Snaketail Rapids ................................ 41, 44

Snow .................................................... 18

Specific conductance ................................... 25

Stambaugh, Goodman soil association ..... 8

Stevens Lake ............................................. 44

Streamflow, accretion ........................... 21, 50

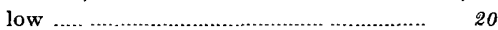




\begin{tabular}{|c|c|c|}
\hline & Page & Page \\
\hline 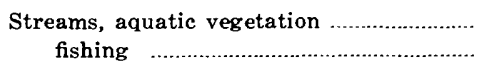 & $\begin{array}{l}46 \\
44\end{array}$ & $\mathbf{W}, \mathbf{Y}$ \\
\hline temperatures & 47 & Water budget ... \\
\hline Sulfate concentrations .. & 23 & Water problems \\
\hline Summary ......................... & 50 & Water quality \\
\hline Surface water & 9,15 & Water table, lakes. \\
\hline $\begin{array}{l}\text { chemical analyses } \\
\text { pesticides }\end{array}$ & $\begin{array}{l}23 \\
25\end{array}$ & $\begin{array}{l}\text { upland areas } \ldots \ldots \ldots \ldots \ldots \ldots \ldots \ldots \ldots \ldots \ldots \ldots \ldots \ldots \ldots \ldots \ldots \ldots \\
\text { wetlands }\end{array}$ \\
\hline quality & 50,51 & Water use \\
\hline 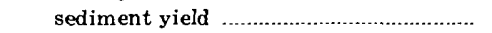 & 25 & nonwithdrawal \\
\hline specific conductance & 25 & recreation \\
\hline storage & 10 & 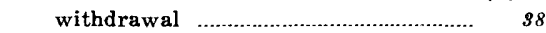 \\
\hline temperatures & 23 & $9,38,39,51$ \\
\hline Swamp deposits & 7 & Wetlands \\
\hline Swimming ......... & 44 & White pines \\
\hline & & 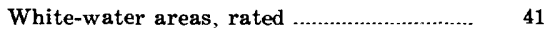 \\
\hline & & Wild river, definition ..................... 2,484 \\
\hline & & Wildlife \\
\hline $\mathbf{T}$ & & Wisconsin Arch \\
\hline & & Wisconsin Wild Rivers Bill ..................... 54 \\
\hline Trapping & 44 & Woods Creek \\
\hline Trout & 47 & Yellow walleyes \\
\hline
\end{tabular}




\section{6 ition}

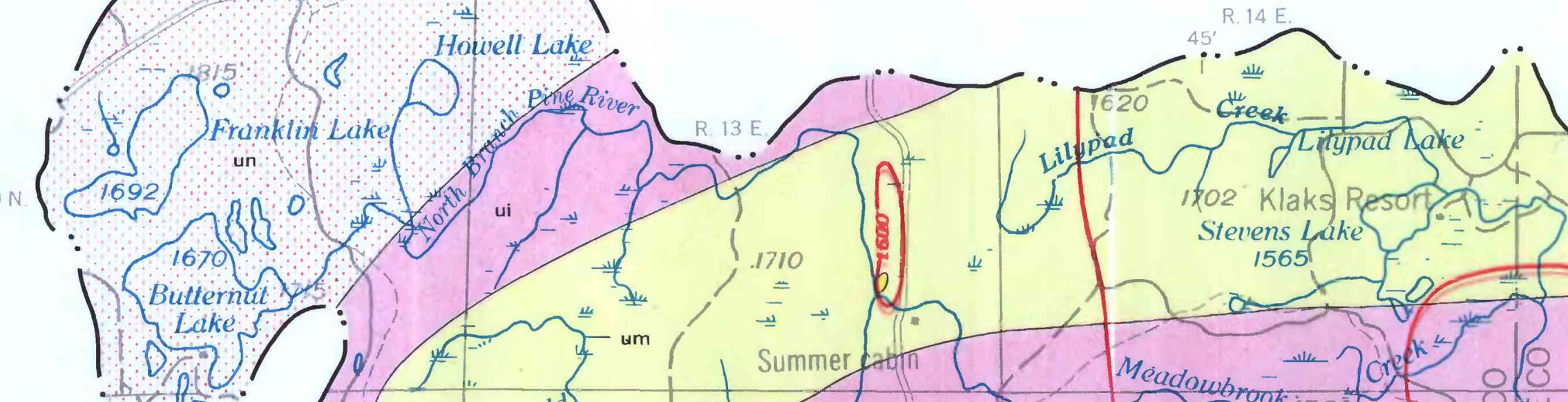
(2)

$1+2=0$
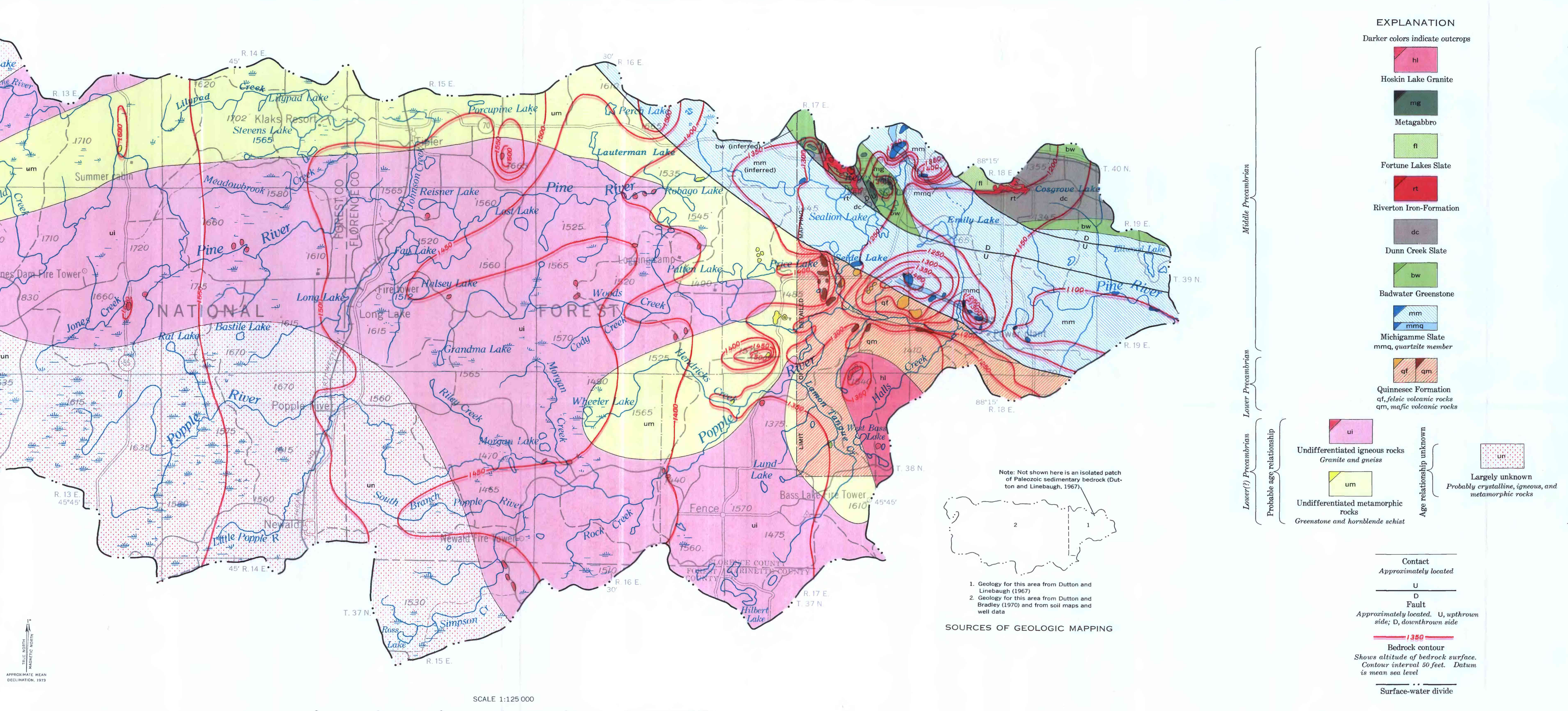

A. GENERALIZED BEDROCK GEOLOGY AND INFERRED CONTOURS ON BEDROCK SURFACE

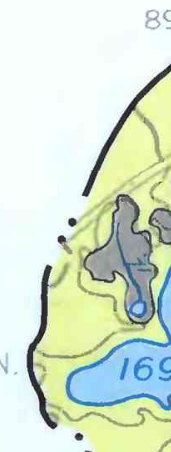

Con

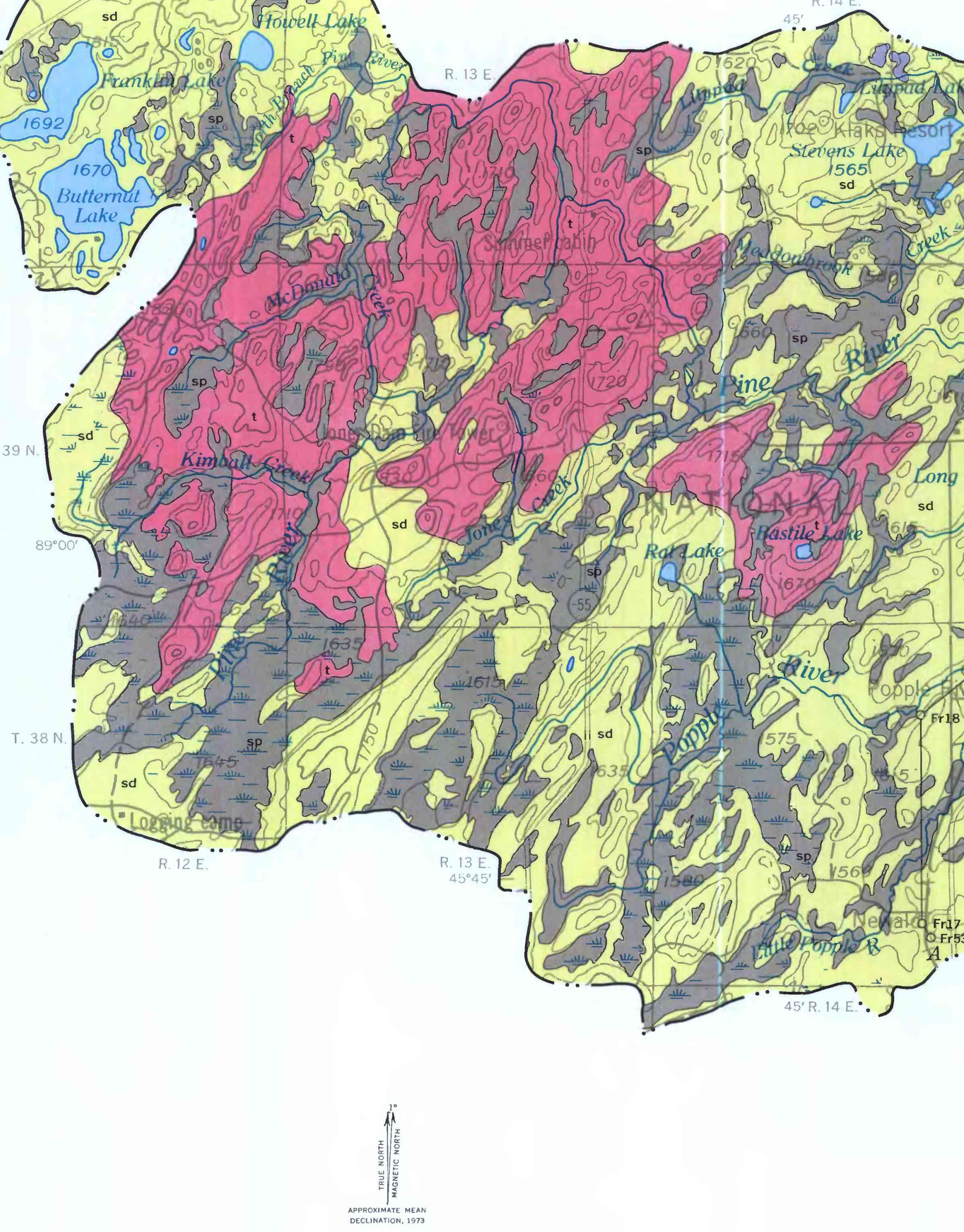

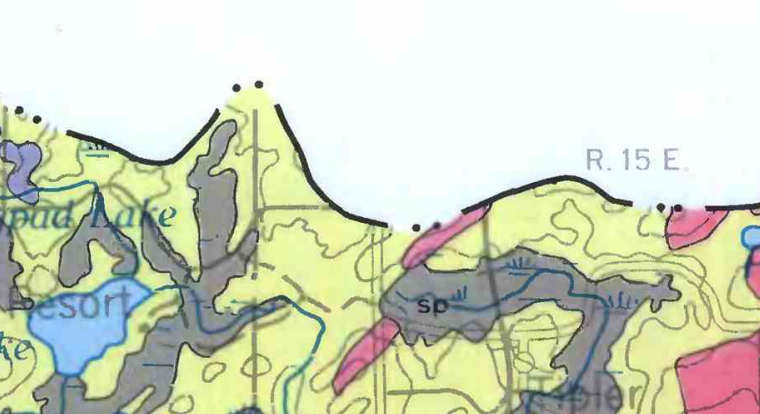

Fen.

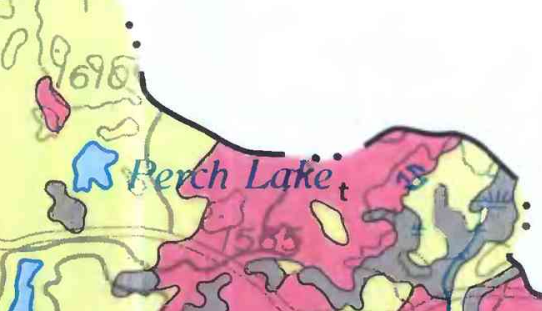

(1)
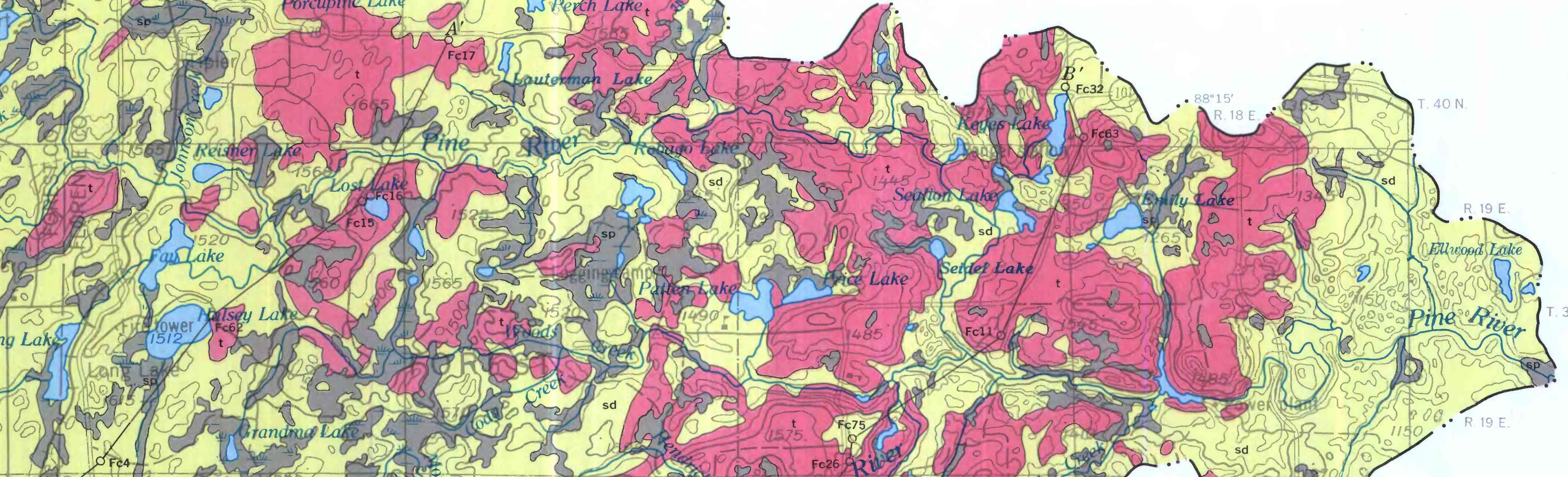

- 250
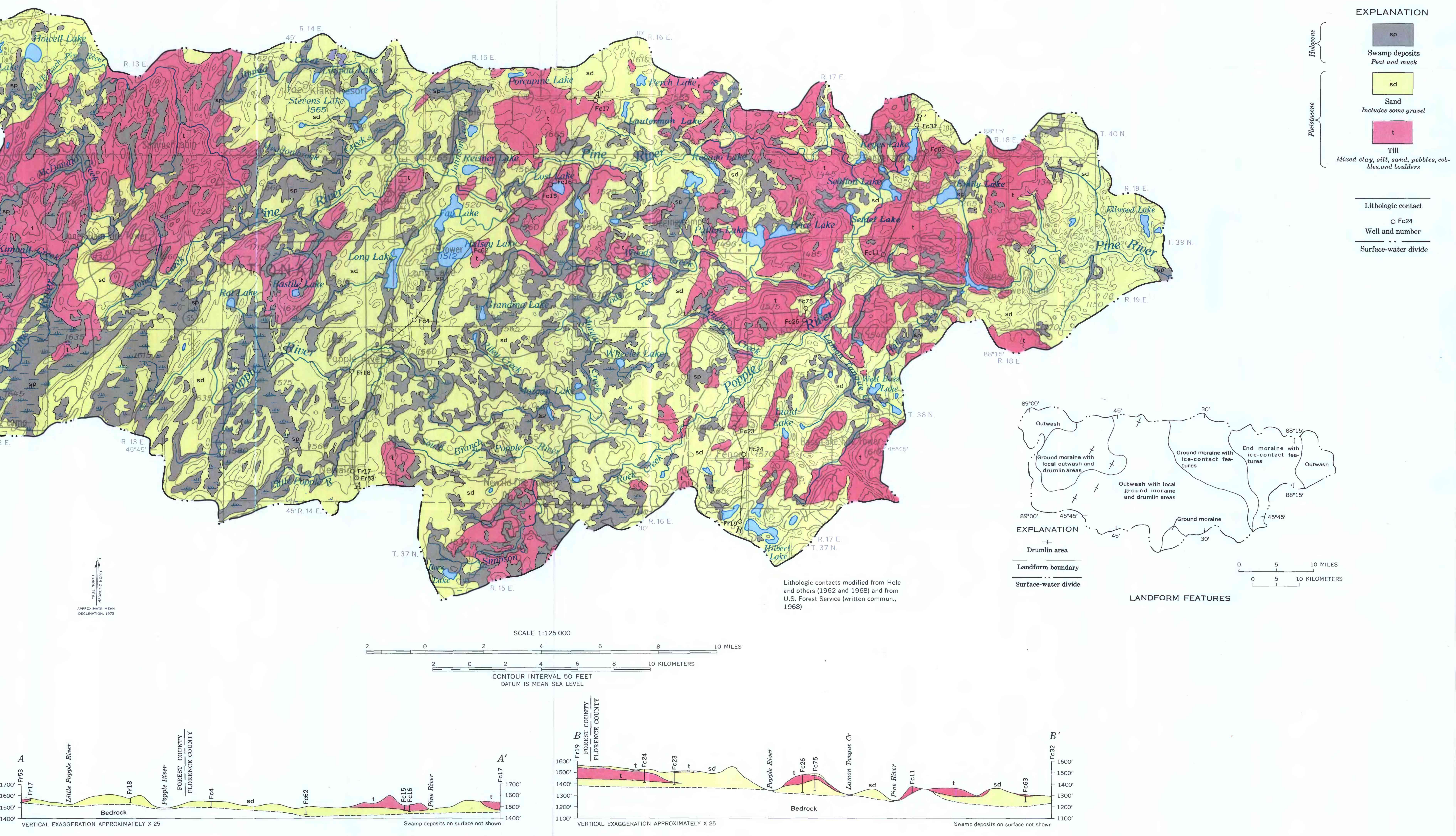

B. SURFICIAL DEPOSITS AND LANDFORM FEATURES 

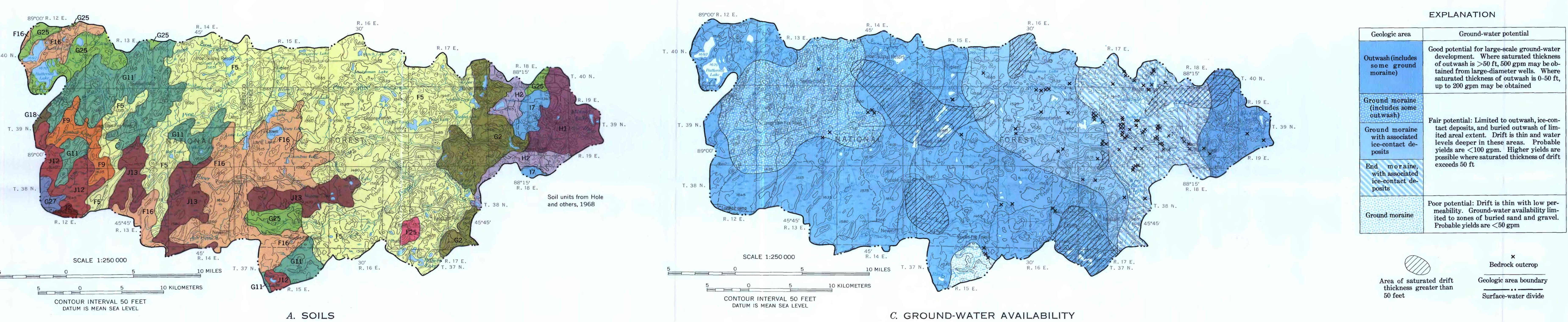

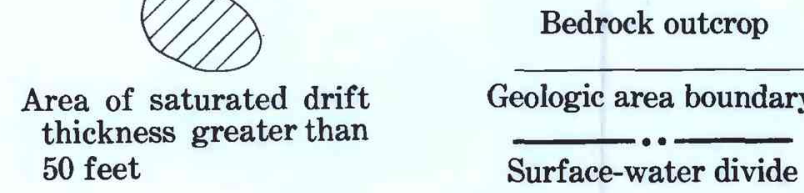
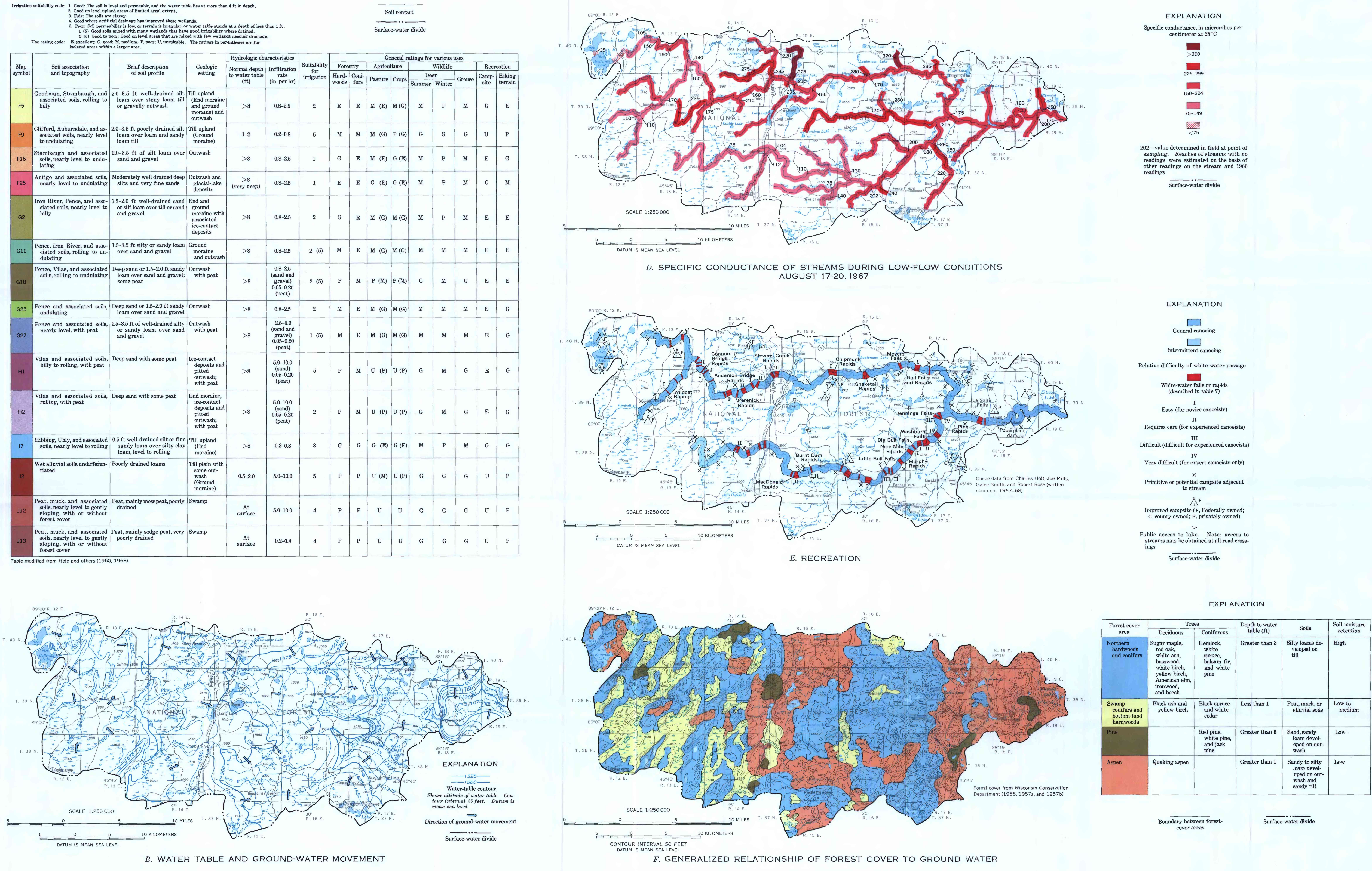